\title{
Assessment of the Effects and Impacts of Hurricane Matthew The Bahamas
}

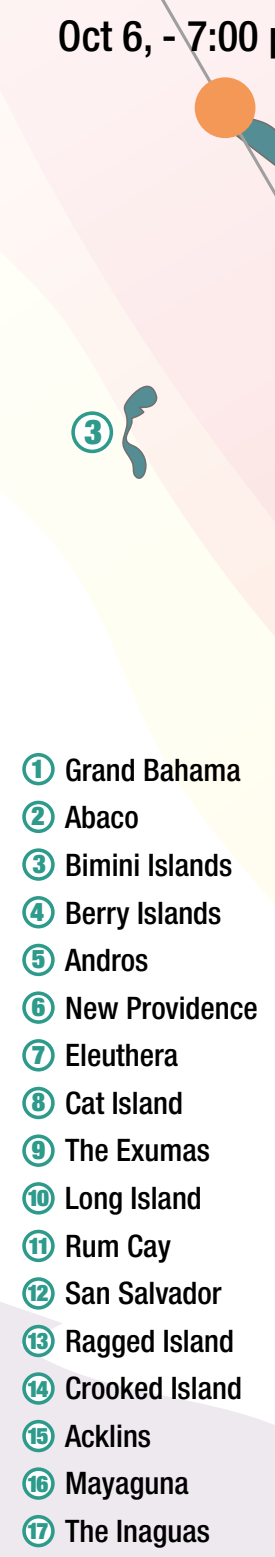

(2)

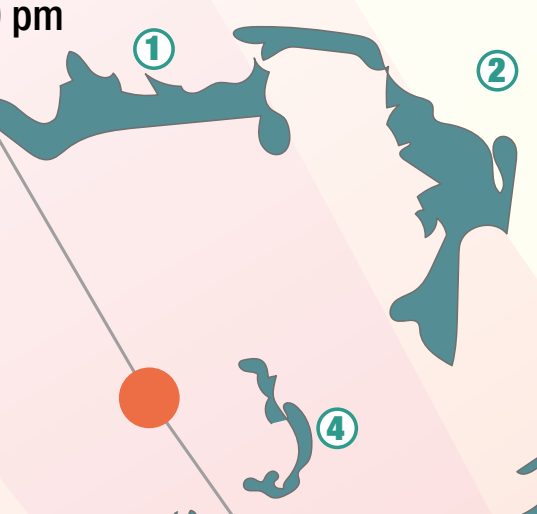





\section{Assessment of the Effects and Impacts of Hurricane Matthew The Bahamas}



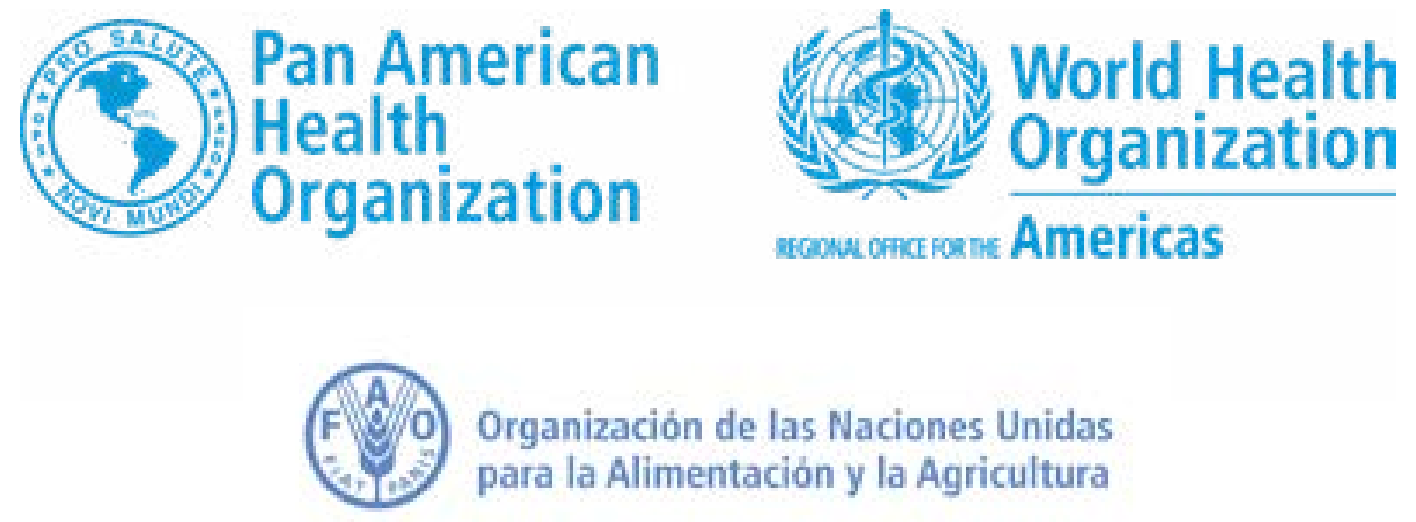

Economic Commission for Latin America and the Caribbean

Omar Bello Mission Coordinator, Affected Population \& Fisheries

Robert Williams Technical Coordinator, Power \& Telecommunications

Michael Hendrickson Macroeconomics

Food and Agriculture Organization

Roberto De Andrade Fisheries

Pan American Health Organization

Gustavo Mery Health

\section{Sector Specialists}

Andrés Bazo Housing \& Water and Sanitation

Jeff De Quattro Environment

Francisco Ibarra Tourism, Fisheries

Blaine Marcano Education

Salvador Marconi National Accounts

Esteban Ruiz Roads, Ports and Air

\section{Inter-American Development Bank}

Florencia Attademo-Hirt Country Representative

Michael Nelson Chief of Operations

Marie Edwige Baron Operations

\section{Editorial Production}

Jim De Quattro Editor 


\section{Contents}

Contents 5

List of tables $\quad 10$

List of figures $\quad 11$

List of acronyms $\quad 13$

$\begin{array}{lr}\text { Executive summary } & 15\end{array}$

$\begin{array}{lr}\text { Introduction } & 19\end{array}$

Affected population $\quad 21$

Housing 21

Health 22

Education 22

Roads, airports, and ports 23

Telecommunications 23

Power 24

Water and sanitation $\quad 24$

Tourism 24

Fisheries $\quad 25$

Environment 26

Economics $\quad 26$

$\begin{array}{ll}\text { Methodological approach } & 27\end{array}$

Description of the event 29

Affected population $\quad 35$

Introduction 35

1. Affected islands $\quad 35$

Demographics $\quad 36$

2. Affected population 37 
SOCIAL SECTORS

Housing $\quad 43$

Introduction 43

1. Baseline information 43

2. Damage 44

Andros $\quad 46$

Grand Bahama $\quad 47$

New Providence $\quad 48$

Berry Islands $\quad 49$

3. Losses 49

4. Additional costs $\quad 50$

Health $\quad 51$

Introduction $\quad 51$

1. Baseline information 52

2. Damage 53

Public clinics 53

Public hospitals $\quad 53$

Other health facilities $\quad 54$

Ministry of Health corporate building 54

3. Losses $\quad 57$

4. Additional costs $\quad 58$

Education $\quad 59$

Introduction $\quad 59$

1. Baseline information $\quad 59$

2. Damage 61

Andros $\quad 61$

The Berry Islands $\quad 61$

Grand Bahama 63

New Providence $\quad 64$

3. Losses 64

4. Additional costs 65 
$\begin{array}{ll}\text { Roads, ports and airports } & 67\end{array}$

Introduction 67

1. Baseline information 68

Road network 68

Airports 69

Ports $\quad 70$

2. Damage 71

Road network: distribution, access and coastal roads 72

Bridges $\quad 73$

Docks $\quad 74$

3. Losses $\quad 75$

4. Additional costs $\quad 75$

$\begin{array}{ll}\text { Telecommunications } & 76\end{array}$

Introduction $\quad 76$

1. Baseline information $\quad 77$

2. Damage 77

3. Losses $\quad 79$

4. Additional costs $\quad 80$

$\begin{array}{ll}\text { Power } & 81\end{array}$

Introduction 81

1. Baseline information 81

2. Damage $\quad 82$

3. Losses $\quad 83$

4. Additional costs $\quad 84$

Water and sanitation $\quad 86$

Introduction $\quad 86$

1. Baseline information 86

Water and sewerage $\quad 86$

Sewerage $\quad 89$

Solid waste $\quad 90$

2. Damage 90

New Providence $\quad 91$

Grand Bahama $\quad 91$

Berry Islands $\quad 92$

Andros $\quad 92$

3. Losses 92

4. Additional costs 93 
$\begin{array}{ll}\text { PRODUCTIVE SECTORS } & 94\end{array}$

$\begin{array}{ll}\text { Tourism } & 95\end{array}$

Introduction $\quad 95$

1. Baseline information $\quad 95$

2. Damage 96

Grand Bahama $\quad 97$

New Providence $\quad 97$

Out Islands $\quad 97$

3. Losses 98

New Providence $\quad 100$

Grand Bahama $\quad 100$

Out Islands $\quad 102$

4. Additional costs 102

$\begin{array}{lr}\text { Fisheries } & 103\end{array}$

Introduction 103

1. Baseline information 103

2. Damage 105

3. Losses 106

Damage to Small Fisheries $\quad 106$

Other Fisheries $\quad 107$

4. Additional costs 107

$\begin{array}{ll}\text { ENVIRONMENTAL SECTOR } & 108\end{array}$

$\begin{array}{ll}\text { Environment } & 109\end{array}$

Introduction 109

1. Baseline information 110

2. Damage 111

Grand Bahama $\quad 111$

New Providence $\quad 114$

Andros $\quad 116$

Summary $\quad 118$

3. Losses 119

4. Additional costs 120

Debris removal $\quad 120$

Oil spill 120

Fire threats $\quad 121$

Comprehensive assessments $\quad 122$

Additional costs summary 122 
Economic impact 125

Evolution of the economy before Hurricane Matthew 125

Economic Activity 125

Fiscal developments 126

Monetary developments $\quad 126$

Balance of payments 127

Impact of Hurricane Matthew on the macro-economy $\quad 128$

Impact on GDP and Prices 128

Fiscal Impact of Hurricane Matthew 128

The Impact of the balance of payments 131

PART II: RECOMMENDATIONS 133

Recommendations for a resilient reconstruction $\quad 135$

Pillar 1: Risk identification $\quad 136$

Pillar 2: Risk reduction $\quad 139$

Human rights 140

Improving the built environment 141

Strengthening institutions for standards and compliance $\quad 143$

$\begin{array}{ll}\text { Pillar 3: Preparedness } & 144\end{array}$

Public early warning systems 144

Public evacuations and sheltering $\quad 145$

Decentralizing response efforts 146

$\begin{array}{lr}\text { Pillar 4: Financial protection } & 147\end{array}$

Pillar 5: Resilient recovery $\quad 149$

Ensuring macroeconomic stability 149

Building sustainable infrastructure $\quad 150$

Conclusion 153

$\begin{array}{ll}\text { References } & 154\end{array}$ 


\section{List of tables}

Table 1 - Effects of Hurricane Matthew by sector. 15

Table 2 - Effects of Hurricane Matthew by island.

Table 3 - Estimated public and private damage, losses and additional costs 20

Table 4 - Demographics of affected islands. 37

Table 5 - Shelters by island and population in shelters. 38

Table 6 - Estimated damage to dwellings by island.

Table 7 - Summary of levels of damage to housing by district, as of 29 0ctober 2016.

Table 8 - Losses due to uninhabitable dwellings in the housing sector. 50

Table 9 - Summary of additional costs to the housing sector. $\quad 50$

Table 10 - Distribution of public clinics in The Bahamas by island. 52

Table 11 - Public hospitals in The Bahamas.

Table 12 - Summary of damage to public health clinics by Hurricane Matthew. 54

Table 13 - Summary of damage in public health facilities, hospitals and others. 55

Table 14 - Damage in public health facilities attributed to Hurricane Matthew. 56

Table 15 - Damage in public hospital and other health buildings attributed to Hurricane Matthew. $\quad 56$

Table 16 - Losses to disruption in health services, equipment. 57

Table 17 - Additional costs associated with emergency response due to Hurricane Matthew. $\quad 58$

Table 18 - Additional cost in overtime hours.

Table 19 - Data on public sector education facilities, teachers and students. 60

Table 20 - Affected education facilities and enrolment by island. 62

Table 21 - Affected education facilities by island. $\quad 63$

Table 22 - Estimated damage to education facilities by island. 63

Table 23 - Estimated loss to education sector by affected island. 65

Table 24 - Total estimated damage, loss and additional costs by affected island. 65

Table 25 - Additional costs associated with Lowe Sound Primary. 65

Table 26 - Airport runways on affected islands. $\quad 69$

Table 27 - Damage summary for transportation sector.

Table 28 - Damage to road network.

Table 29 - Damage to sea walls. $\quad 73$

Table 30 - Damage to bridges. $\quad 74$

Table 31 - Damage to docks.

Table 32 - Summary of additional costs (\$) in the infrastructure sector. $\quad 75$

Table 33 - Damage by island and type of telecommunications service. $\quad 79$

Table 34 - Losses in the telecommunications sector. $\quad 79$

Table 35 - Additional costs in the telecommunications sector. $\quad 80$

Table 36 - Summary of damage in the power sector. $\quad 82$

Table 37 - Estimated loss in the power sector.

Table 38 - Additional costs in the telecommunications sector.

Table 39 - Water supply in private dwellings in The Bahamas.

Table 40 - Sanitation dependence in private dwellings. $\quad 90$

Table 41 - Additional costs in the water and sanitation sector. 93

Table 42 - Summary of damage in the tourism sector. $\quad 96$

Table 43 - Total losses in 2016 by type of visitor. 99

Table 44 - Total losses in 2016 by type of expenditure. 99 
Table 45 - New Providence losses in 2016 by type of visitor. 101

Table 46 - Grand Bahama losses by type of visitor. 101

Table 47 - Out Islands losses by type of visitor. 102

Table 48 - Summary of additional costs in the tourism sector. 102

Table 49 - Damage to small fisheries. 106

Table 50 - Small fisheries losses, October to December 2016 (\$). 106

Table 51 - Estimated cost to environmental sector. 111

Table 52 - Estimated damage to beach dunes, Grand Bahama. 113

$\begin{array}{ll}\text { Table } 53 \text { - Summary of damage to the environmental sector. } & 119\end{array}$

$\begin{array}{ll}\text { Table } 54 \text { - Losses to environmental sector for selected ecosystem areas. } & 119\end{array}$

Table 55 - Estimated cost of debris removal and disposal. $\quad 120$

Table 56 - Estimated cost of prescribed wildland fire strategy. 122

Table 57 - Additional costs to the environment sector. 123

$\begin{array}{lr}\text { Table } 58 \text { - Impact of Hurricane Matthew on government fiscal operations. } & 129\end{array}$

$\begin{array}{ll}\text { Table } 59 \text { - Pillars for disaster risk reduction. } & 136\end{array}$

Figure 1 - Wind swath of Hurricane Matthew. $\quad 29$

Figure 2 - Path of Hurricane Matthew in The Bahamas. 32

Figure 3 - Conch shells used as an aggregate in concrete slab destroyed 47

Figure 4 - Photos showing front walls, buildings and other major damage $\quad 48$

Figure 5 - Fallen trees and accumulations of organic debris. 49

Figure 6 - Pavement structure and draining problems, South Beach San Andreas. $68 z$

$\begin{array}{ll}\text { Figure } 7 \text { - Affected airports in Berry Islands and New Providence. } & 69\end{array}$

Figure 8 - Affected docks in West End and Berry Islands.

$\begin{array}{ll}\text { Figure } 9 \text { - Affected bridge, Conch Sound vicinity. } & 73\end{array}$

Figure 10 - Daily peak load readings for New Providence in 0ctober. 83

$\begin{array}{ll}\text { Figure } 11 \text { - Diagram of vulnerability of groundwater supply. } & 87\end{array}$

Figure 12 - Bathroom and septic tank system affected by flooding in the West End settlement. $\quad 91$

$\begin{array}{lr}\text { Figure } 13 \text { - Income and income losses (\$). } & 99\end{array}$

Figure 14 - Primary and overall fiscal balances before and after Hurricane Matthew. $\quad 130$

$\begin{array}{ll}\text { Figure } 15 \text { - Coastal vulnerability index (CVI) in North Andros. } & 137\end{array}$

$\begin{array}{lr}\text { Figure } 16 \text { - Map detail from the U.S. National Hurricane Centre's } & 139\end{array}$

$\begin{array}{ll}\text { Figure } 17 \text { - Multipoint foundations. } & 143\end{array}$ 



\section{List of Acronyms}

\begin{tabular}{|c|c|}
\hline ARPU & Average Revenue Per User \\
\hline BEC & Bahamas Electricity Company \\
\hline BNT & Bahamas National Trust \\
\hline BNTDR & Bahamas National Trust Damage Report \\
\hline BPL & Bahamas Power and Light \\
\hline BTC & Bahamas Telephone Company \\
\hline BTC & Bahamas Telecommunications Company \\
\hline CARILEC & Caribbean Electric Utility Services Corporation \\
\hline CCRIF & Caribbean Catastrophe Risk Insurance Facility \\
\hline CDEMA & Caribbean Disaster Emergency Management Agency \\
\hline CVI & Coastal Vulnerability Index \\
\hline DALA & Damage and Loss Assessment \\
\hline ECLAC & Economic Commission for Latin America \\
\hline EEZ & Exclusive Economic Zone \\
\hline FAO & Food and Agriculture Organisation \\
\hline GBPA & Grand Bahama Port Authority \\
\hline GBPC & Grand Bahama Power Company \\
\hline GBUC & Grand Bahama Utility Company \\
\hline GDP & Gross domestic product \\
\hline GFDRR & Global Facility for Disaster Reduction and Recovery \\
\hline IDB & Inter-American Development Bank \\
\hline MEH & Ministry of Environment and Housing \\
\hline MoEST & Ministry of Education, Science and Technology \\
\hline $\mathrm{MOH}$ & Ministry of Health \\
\hline MOW & Ministry of Works \\
\hline MRAG & Marine Resources Assessment Group \\
\hline NatCap & Natural Capital \\
\hline NEMA & The Bahamas' National Emergency Management Agency \\
\hline NewCo & NewCo 2015 Limited \\
\hline NGO & Non-government organisations \\
\hline NOAA & National Oceanic and Atmospheric Administration \\
\hline NPDC & New Providence Development Company \\
\hline РАHO & Pan American Health Organisation \\
\hline PHA & Public Hospital Authority \\
\hline PU & Paradise Utility \\
\hline
\end{tabular}





\section{Executive Summary}

The passage of Hurricane Matthew through The Bahamas in October 2016 marks the second time in just over a year that the country was affected by a Category 4 hurricane. However, unlike 2015's Hurricane Joaquin, which affected islands having a relatively low population, Hurricane Matthew's greatest impact was felt on the country's population centres of New Providence and Grand Bahama, as well as in the district of North Andros. Damage in these areas was caused by high winds and storm surge associated with the hurricane, and was exacerbated by construction practices and the siting of communities and infrastructure in vulnerable locations.

Soon after the hurricane passed, the government of The Bahamas asked the Inter-American Development Bank (IDB) to assess the resulting damages, losses and additional costs. The IDB requested assistance from the United Nations Economic Commission for Latin America and the Caribbean (ECLAC) for technical assistance with the assessment. This report presents results of the assessment. It also presents recommendations to guide a resilient reconstruction process that can reduce vulnerabilities and risks for the population and for every sector of the economy.

Hurricane Matthew cost The Bahamas more than three times as much as Hurricane Joaquin. The total cost is approximately $\$ 580.4$ million. This cost consists of three elements: direct physical damage, revenue and other income losses, and additional costs-chiefly debris removal. Table 1 summarises estimates of damage, loss and additional cost for the four primary economic sectors on the affected islands: social, infrastructure, productive and environment.

Table 1- Effects of Hurricane Matthew by sector

\begin{tabular}{|c|c|c|c|}
\hline Sector & Damage & Losses & Additional costs \\
\hline Social & $203,842,183$ & $14,494,468$ & $18,697,137$ \\
\hline Infrastructure & $38,173,233$ & $21,627,137$ & $36,311,640$ \\
\hline Productive & $130,172,750$ & $109,339,805$ & $1,515,484$ \\
\hline Environment & $1,723,735$ & 72,364 & $4,373,400$ \\
\hline Total & $\mathbf{3 7 3 , 9 1 1 , 9 0 1}$ & $\mathbf{1 4 5 , 5 3 3 , 7 7 4}$ & $\mathbf{6 0 , 8 9 7 , 6 6 1}$ \\
\hline
\end{tabular}

Source: Assessment Team, 2016 
Effects of Hurricane Matthew on the population were moderate. No deaths or injuries to persons were reported due to the event. The main impact was suffered in the housing sector. The quality of life of the population temporarily decreased due to disruptions to services such as health, electricity, telecommunications and transport. Electrical power was the most broadly affected public service; about 127,000 consumers were left without electricity after the hurricane. Electrical outages also affected availability of drinking water. In addition, reports indicate that 3,221 people were sheltered in 50 facilities throughout the four affected islands analysed in this report during Hurricane Matthew and in the days following. ${ }^{1}$ Most families who went to shelters stayed only a short time. About 13,354 students were affected by the suspension of classes.

Total hurricane damage, estimated at $\$ 373.9$ million, accounted for almost two-thirds of the storm's total cost. Most damage was to the housing sector, and the tourism sector

The productive sectors-tourism and fisheries-account for nearly \$109.3 million of the total $\$ 145.5$ million in income losses caused by the hurricane. Fisheries have the highest ratio of income loss to damage. For each dollar of hurricane damage, there was \$25 of lost income in the fisheries sector.

Of the $\$ 60.9$ million in additional costs attributed to the hurricane, approximately 60 per cent $-\$ 36.3$ million-was borne by the infrastructure subsectors-transportation, telecommunications, power, and water and sanitation. About 93 per cent of the additional costs in infrastructure occurred in the power (\$23.6 million) and telecommunications $(\$ 10.3$ million) sectors.

Table 2 displays the total hurricane costs by island. Nearly seventy per cent of the total cost occurred in Grand Bahama; 23 per cent, in New Providence. Andros accounts for 4.6 per cent of the total and the Berry Islands for 0.3 per cent.

Table 2- Effects of Hurricane Matthew by island

\begin{tabular}{|l|r|r|r|}
\hline \multicolumn{1}{|c|}{ Sector } & Damage & \multicolumn{1}{c|}{ Losses } & \multicolumn{1}{c|}{ Additional costs } \\
\hline New Providence & $66,592,169$ & $48,595,219$ & $15,399,436$ \\
\hline Grand Bahama & $278,478,581$ & $88,519,161$ & $41,032,663$ \\
\hline Andros & $20,671,803$ & $2,046,947$ & $3,729,189$ \\
\hline Berry Islands & $1,475,966$ & 144,169 & 323,564 \\
\hline Other islands & $6,692,882$ & $6,228,279$ & 412,810 \\
\hline
\end{tabular}

Source: Assessment Team, 2016 
Not all of the hurricane's impacts are as visible as destroyed homes, downed power lines, the absence of tourists, or the piles of debris on roadsides.

The hurricane has affected the growth rate of the country's gross domestic product (GDP), reducing the growth rate by 1.1 percentage points. Before Hurricane Matthew, the projected GDP growth rate for 2016 was 0.5 per cent. Following this disaster, based on estimates of losses and additional costs, a GDP of minus 0.6 per cent is projected.

Damage, losses and additional costs of the hurricane are far more difficult to quantify in dollars for the environment sector. But it is not possible to overestimate the value of the environment. The country's two largest productive sectors-tourism and fisheries-depend on the country's unique and irreplaceable natural resources. Hurricane damage to the environment may have a disproportionate effect on the productive sectors, compared to the other sectors of the economy.

To assess the hurricane's impact, ECLAC team members conducted site visits to the areas most affected, including southern New Providence, western Grand Bahama, North Andros and the Berry Islands. The team also interviewed and met with sector specialists from 23 to 29 October, 2016. Information in this report was obtained from many institutions of the government of The Bahamas, non-governmental organizations, local inhabitants and from observations during the field visits. The team also identified data gaps. These gaps present the main limitation to the findings. All monetary estimates are made in Bahamian dollars; to simplify we use the symbol \$.

Based on the information received and observations from sector specialists, the last chapter of the report proposes a series of recommendations intended as a framework for a resilient reconstruction process that considers the most relevant findings in each sector. A comprehensive and resilient reconstruction process requires a combination of structural and non-structural measures to reduce social, economic and environmental vulnerabilities, rather than isolated measures. 



\section{Introduction}

After cutting a swath through the eastern, southern and central Caribbean, Hurricane Matthew arrived in the southern Bahamas as a Category 3 hurricane on 5 October 2016. It proceeded on a north-westerly course, paralleling the long axis of the island chain, and strengthening to a Category 4 storm the next morning as its centre of circulation passed through the channel between Andros and New Providence. The storm's eye continued past the Berry Islands and across the extreme western tip of Grand Bahama before moving on to the eastern seaboard of the United States.

In The Bahamas, the storm left heavy damage in its wake, particularly from storm surge in North Andros, western Grand Bahama and southern New Providence, and wind damage that affected the country's most populated cities of Nassau and Freeport. Fortunately, Matthew had been anticipated for days, providing ample time to warn the public, allowing people to evacuate low-lying areas and move into shelters in advance of the storm. This is in contrast to 2015's Hurricane Joaquin, which arrived unexpectedly in the country's southern islands, leaving little time for warning and evacuation to shelters.

Hurricane Matthew cost The Bahamas more than four times the cost of Hurricane Joaquin. The total cost was approximately $\$ 580.4$ million. Damage accounted for 64.2 per cent of the total, followed by losses and additional costs of 25.1 and 10.5 per cent, respectively. The social sector absorbed 42 per cent of the cost, followed by the social sectors, 41.5 per cent.

Table 3 displays the costs to the public and private categories of each sector and subsector of the economy. Approximately 87.6 per cent of the hurricane's total cost occurred in the private sector. Similar percentages hold for both private-sector damage and private-sector losses. Of the total additional costs, however, slightly approximately 60 per cent occurred in the public sector. 
Table 3- Estimated public and private damage, losses and additional costs of Hurricane Matthew by economic sector and subsector

\begin{tabular}{|c|c|c|c|c|c|c|}
\hline Sector & Public & Private & Public & Private & Public & Private \\
\hline SOCIAL SECTORS & $3,754,262$ & $200,087,921$ & $3,550,738$ & $10,943,730$ & $7,490,383$ & $11,206,754$ \\
\hline -Education & $2,870,255$ & & $1,795,979$ & & 91,975 & \\
\hline -Housing & & $200,087,921$ & & $10,943,730$ & & $11,206,754$ \\
\hline -Health & 884,007 & & $1,754,759$ & & 398,408 & \\
\hline $\begin{array}{l}\text {-Emergency } \\
\text { response }\end{array}$ & & & & & $7,000,000$ & \\
\hline $\begin{array}{l}\text { INFRASTRUCTURE } \\
\text { SECTORS }\end{array}$ & $24,283,203$ & $13,889,530$ & $12,776,418$ & $8,850,719$ & $13,823,058$ & $22,488,582$ \\
\hline $\begin{array}{l}\text {-Water and sani- } \\
\text { tation }\end{array}$ & $1,200,000$ & & 180,600 & & 528,000 & \\
\hline $\begin{array}{l}\text {-Roads, ports and } \\
\text { airports }\end{array}$ & $10,774,233$ & & & & $1,899,068$ & \\
\hline -Power & $7,243,500$ & $9,100,000$ & $5,607,339$ & $2,242,936$ & $6,120,000$ & $17,500,000$ \\
\hline $\begin{array}{l}\text {-Telecommunica- } \\
\text { tions }\end{array}$ & $5,065,470$ & $4,789,530$ & $6,988,479$ & $6,607,783$ & $5,275,990$ & $4,988,582$ \\
\hline $\begin{array}{l}\text { PRODUCTIVE } \\
\text { SECTORS }\end{array}$ & 0 & $130,172,750$ & 0 & $109,339,805$ & 0 & $1,515,484$ \\
\hline -Tourism & & $129,339,250$ & & $88,317,749$ & & $1,490,484$ \\
\hline -Fisheries & & 833,500 & & $21,022,056$ & & 25,000 \\
\hline $\begin{array}{l}\text { ENVIRONMENT } \\
\text { SECTOR }\end{array}$ & $1,702,150$ & 21,585 & 72,364 & & $4,373,400$ & \\
\hline TOTAL & $\$ 29,740,115$ & $\$ 344,171,786$ & $\$ 16,399,520$ & $\$ 129,134,254$ & $\$ 36,893,595$ & $\$ 24,004,066$ \\
\hline
\end{tabular}

Source: Assessment Team, 2016

The sector distribution of damage is as follows: 54.5 per cent in the social sector, 10.2 per cent in infrastructure, 34.8 per cent in the productive sectors and 0.5 per cent in the environment. In the social sectors, 98.2 per cent of damages occurred in housing. In infrastructure, 42.8 per cent of damages was to the electrical power sector. In the productive sectors, 99.4 per cent of damages occurred in the tourism sector.

For losses, the sector distribution is 75.1 per cent in the productive sectors, 14.9 per cent in infrastructure, 9.9 per cent in social sectors and 0.1 per cent in the environment. In the productive sectors 80.7 per cent of losses occurred in tourism. In the infrastructure sectors 62.9 per cent of losses occurred in telecommunications. Finally, in the social sectors 75.5 per cent of losses occurred in housing.

Approximately 60 per cent of the hurricane's additional costs occurred in infrastructure sectors, followed by social sectors with 30 per cent. 


\section{Affected population}

The effects of Hurricane Matthew on the population were, on average, moderate. There were no deaths or serious injuries reported. The major impact was in the housing sector. The quality of life of population temporarily decreased due to disruptions to services such as health, electricity, telecommunications and transport. Approximately 2,630 dwellings were damaged, affecting 8,931 people. The most severe damage was sustained in 917 dwellings (Level 3 and Level 4) that had accommodated about 3,093 residents.

Reports indicate that 3,221 people were sheltered in 50 facilities throughout the four affected islands analysed in this report during Hurricane Matthew and in the following days. ${ }^{2}$ Most families had short stays in shelters.

Regarding education, approximately 13,354 students were affected by the suspension of classes. In several islands, closures began before the arrival of the hurricane and mostly ended by 25 October.

Power was the most affected public service. An estimated 127,000 consumers were without electricity after the hurricane. This also had an impact on water and sanitation. Another sector affected by lack of electricity was the education sector. In Grand Bahama, during site visits by the evaluation team on 24 October, some schools reported that lack of electricity was the main problem preventing full-time resumption of classes.

With regard to the livelihoods of the affected population, small producers in the fishing sector suffered most. Based on estimation of the macro-economic impact, workers in this sector lost $\$ 13.7$ million dollars in remunerations.

\section{Housing}

Housing is one of the sectors most severely affected by Hurricane Matthew. Some low-lying settlements along or near coastlines suffered heavy damage as a result of storm surge, and houses throughout the islands suffered wind damage to roofs, water damage as a result of rain intrusion, or were impacted by falling trees and flying debris.

Damage to the housing sector on New Providence, Grand Bahama, Andros, and the Berry Islands is estimated at \$200.1 million. The ECLAC team calculates losses of $\$ 10.9$ million. Additional costs are estimated at $\$ 11.2$ million. This consisted of removing rubble, cleaning out destroyed dwellings and renting equipment. 


\section{Health}

The health sector suffered moderate effects from Hurricane Matthew. The most severely affected were Andros, Berry Islands, Grand Bahama and New Providence. The latter two are the country's most highly populated islands and host its two largest cities, Freeport and Nassau. These urban centres also concentrate most health care centres and services. The health infrastructure seems more resilient in these major urban centres than in the Family Islands.

The total cost of Hurricane Matthew for the country's health sector is estimated at $\$ 3,037,174$. Most damage was caused by wind and flooding or water intrusion. Two clinics were identified as severely damaged. Damage was estimated at $\$ 884,007$.

Losses in the sector related to the interruption of activities before, during and after Hurricane Matthew. After the hurricane, normal operations were not restored in some facilities due to damage or disruption in essential services such as electricity and water supply. Losses are estimated at $\$ 1,754,759$.

Additional costs considered in this report include gas to power generators in health facilities, food provided during emergency operations, residential rental facilities, and paying overtime staff to provide extraordinary hours of service. Additional costs are estimated at $\$ 398,408$.

\section{Education}

The education sector suffered moderate damage from the hurricane. There are 34 schools and 13,354 students within the affected regions. The single most impacted school was Lowe Sound Primary School in North Andros, which was flooded by storm surge on Thursday, 6 October. Teachers and students had to be relocated to a new facility established on short notice.

Many schools were closed for just over two weeks to allow for clean-up and repairs. This contributed to a total loss of 92,712 student hours. Most additional costs are associated with removal of debris and an increase in subscriptions to school feeding programmes.

The total estimated cost of Matthew to the education sector in The Bahamas is $\$ 4,758,208$. Most of this is due to damage to school property of $\$ 2.9$ million. Estimated education loss-measured as the value of about 12 school days of lost teaching time for schools in the affected area-is at least $\$ 1.1$ million. Additional costs are $\$ 91,975$, primarily associated with the relocation of the school in Andros. Around 48 per cent of the total estimated combined damages, losses and additional costs are for 
Grand Bahama island, 23 per cent for New Providence and 15 per cent for Andros and the Berry Islands. The remaining 14 per cent of the total is attributed to the overall loss associated with the closure of all schools in the country before and during Hurricane Matthew.

\section{Roads, airports, and ports}

Damage to this sector was caused primarily by surge flooding. Surges affected roads, airports, bridges, docks and fences in New Providence, Andros, Grand Bahama and the Berry Islands. The estimated damage is $\$ 10,774,733$. Estimated additional costs are $\$ 1,899,098$, mainly related to debris removal and fencing.

In general, port structures suffered minor damage to pillars and to loading areas made of concrete slabs. The damages seen result from noncompliance with structural criteria; for this kind of condition, these structures require proper steel reinforcement, which in some cases was absent. They also require adequate concrete mix poured so that any aggregate (stone, gravel, etc.) will make up more than a third of the slab's camber. The use of beach sand or similar material is not recommended because it generates rust on the steel used for reinforcement and, even when used properly, is more expensive because other components are needed to give the concrete adequate resistance for a particular structure.

\section{Telecommunications}

Though wireless telecommunications services were fairly resilient considering the magnitude of the storm, there were extensive outages to wired services including landline telephone, fixed internet and cable television systems. The most prolonged outages occurred in Grand Bahama, followed by New Providence. Andros was affected through partial collapse of an important telecommunications tower, and several cellular installations lost service in the Berry Islands. Damage to telecommunications infrastructure was also reported in Inauga, Acklins, Exuma, Long Island and Bimini.

Damages in the telecommunications sector are estimated at $\$ 9.86$ million, losses at $\$ 13.60$ million, and additional costs at $\$ 10.26$ million. Total effects of the storm on the telecommunications sector are estimated at $\$ 33.72$ million. This is about 50 per cent more expensive than the total costs associated with Hurricane Joaquin in the telecommunications sector. Though there was less damage to cellular base stations and high-value electronics equipment by this storm than by Hurricane Joaquin, the overall cost was driven higher by prolonged outages to cable television, fixed-wire telephone lines, and broadband internet services in highly populated areas. 


\section{Power}

Most of the damage in the power sector was to transmission, distribution and service lines as a result of high winds that felled utility poles and caused trees to collapse onto power lines. The storm passed very close to Clifton Pier Power Station at the western end of New Providence. The station was damaged by high winds and storm surge. The generation station at Fresh Creek, Andros, was damaged when winds blew away the building housing its generators.

Restoration of power took several weeks, with longer delays in remote settlements far from population centres. Grand Bahama was most affected by long-term power outages; the last area to be energized, in West End, came back online five weeks after the storm. In New Providence, power was restored within three weeks, though isolated outages remained due to service line damages for individual customers. In Andros, power was restored to almost all communities by 28 October, except the hardest-hit area of Lowe Sound, where 127 customers remained without power as a result of the high level of destruction to housing and infrastructure.

In the power sector, damages are estimated at $\$ 16.35$ million, losses at $\$ 7.85$ million, and additional costs at $\$ 23.62$ million. The total cost of Hurricane Matthew on the power sector is estimated to be $\$ 47.81$ million.

\section{Water and sanitation}

Water and sewer infrastructure did not suffer substantial damage in the islands assessed. In most cases, distribution lines were destroyed or showed leaks and varying degree of damage to electrical installations, water mains and service connections. This service was suspended in nearly all the affected islands due to the loss of electricity. Damage to infrastructure was considerable in desalination plants in Windsor and Blue Hills. ${ }^{3}$ According to the Water and Sewerage Corporation, total damage is $\$ 1,200,000$.

Due to the interruption of water distribution service to dwellings, estimated losses are $\$ 180,600$. Additional costs of $\$ 528,009$ are estimated for managing the debris that arrived at landfills, disaster assessment and recovery teams deployed in several islands, and rental equipment to fulfil these works.

\section{Tourism}

The tourism sector suffered considerable costs because of Hurricane Matthew. The most common physical damage was to roofs and ceilings of tourist facilities and was caused by high winds. This damage was 
particularly severe on Grand Bahama and in the northern and central districts of Andros. There was also water damage due to wind-broken windows and doors, but most water damage came from storm surges on 6 October. Surges were particularly devastating in areas of North Andros and the West End of Grand Bahama, but they also affected south Nassau. Besides physical damage, the hurricane caused the loss of tourism revenue.

Most of the hurricane risk to The Bahamas tourism sector is due to exposure to storm surge. Because proximity to the sea is critical to the country's tourism industry, the risk of storm surges will continue. Therefore, measures to mitigate the risks and the impacts of water surge in tourism facilities are desirable.

The total estimated cost of Hurricane Matthew to the tourism sector is $\$ 219.2$ million. The estimated damage to tourism infrastructure is US\$ 129 million, mostly in Grand Bahama. The estimated losses are \$88.3 million, also the majority of them located in Gran Bahama. It is estimated that 29.8 per cent of the losses will take place in 2017. The additional cost, primarily debris removal, is estimated at $\$ 1.5$ million.

Grand Bahama accounts for around 75 per cent of the Hurricane's estimated total cost to The Bahamas' tourism sector; New Providence, 21 per cent, and the Out Islands about 4 per cent.

\section{Fisheries}

For the evaluation of this sector, the procedure ${ }^{4}$ was the following. First, through on-site interviews and visual inspection, information was obtained on destruction of assets in a) Lowe Sound in North Andros and b) West End in Grand Bahama, which were severely affected. Production of the fisheries in both villages is mainly done by small-scale producers. This group will be called small fishing. This can be seen as study cases and not as a sample to make an inference.

The second type of information used in this assessment is based on the sector's aggregate production data for 2016. It is reasonable to assume that fishery assets were not harmed, but their production flow may be altered due to the effects of hurricane. We call this group other fisheries and will mainly estimate the losses.

The estimated total damage in small fisheries is $\$ 833,500$. The losses are $\$ 422,057$. Losses from other fisheries are $\$ 20.6$ million. Total losses are $\$ 21.0$ million. The additional cost is mainly related to debris removal and is estimated at $\$ 25,000$. 


\section{Environment}

Coral reefs, seagrass meadows, beaches, mangrove forests and native broadleaf forests in The Bahamas have adapted over time to become resilient to tropical weather. Wave action, storm surge and high winds during Hurricane Matthew caused a wide range of damages to those ecosystem types, with the brunt of the damages occurring in pockets of native hardwoods/coppice forests and other non-pine species including fruit trees. Other coastal ecosystem types including coral reefs, beaches, mangrove marshes and seagrass meadows appeared to have fared very well during the storm event.

Some seagrass meadows were visibly damaged on Grand Bahama and Andros, but seagrasses in the Caribbean have a tendency to recover quickly from tropical storms. The resource should recover quickly, but the damage to seagrasses beds is likely to have short- to medium-term effects ( 2 to 4 years) on the services they provide to lobster and conch fisheries. ${ }^{5}$

Visual inspections of three coral reef areas revealed that, while sediment around the reefs was either missing or more abundant, reefs fared well in the high currents or waves produced by Matthew. There was some fragmentation of the softer and branching corals at reefs south of Nassau and south of New Providence, but the damage appeared minimal.

Mangrove areas observed on New Providence and Andros also fared well from the storm surge, flooding and wave action. Mangrove trees are well adapted to these tropical storm events, and the trees likely prevented or lessened storm damages to adjacent property.

The most damaged natural resource appears to be native hardwoods and other non-pine tree species in New Providence, Grand Bahama andprimarily-Andros. Forests in The Bahamas are valued less for their marketable timber and more for important services they provide to the Bahamian economy and ecology.

The estimated damage in the environment sector is approximately $\$ 1.7$ million. These damages are a product of impacts on coral reefs and beaches and on the infrastructure of protected zones. Losses are estimated at $\$ 72,364$ and additional costs at approximately $\$ 4.4$ million.

\section{Economics}

Matthew lowered the GDP growth rate. Before the hurricane, the projected GDP growth rate for 2016 was 0.5 per cent. Afterwards, based on estimates of losses and additional costs, a GDP decrease of 0.6 per cent is projected. Consistent with this result, the payroll of the economy

\footnotetext{
5. The value of these services is not estimated due to lack of assessment data. Lobster and conch utilize seagrass beds for reproduction, foraging and seeking refuge. These services were likely disrupted in localized areas around the impacted islands. Seagrasses throughout the Bahamian islands provide other services including nutrient cycling, sediment stabilization, carbon sequestration, food for sea turtles, and preventing shoreline erosion (Clavelle et al. 2013). However, these services are not likely to have been disrupted by Matthew.
} 
would be decreased by $\$ 17.9$ million, of which 76.5 per cent, or $\$ 13.7$ million dollars, represents a decrease in payroll in the tourism sector. The loss of capital income, which includes the operating surplus (remuneration to the formal sector) and mixed income (remuneration to the informal sector), is $\$ 37.7$ million, explained mainly by a $\$ 17.1$-million reduction to income of formal entrepreneurs in the tourism sector (hotels and restaurants) and the \$15.8-million contraction of income of individual entrepreneurs in the fishing sector.

\section{Methodological approach}

The assessment of the effects and impacts caused by Hurricane Matthew follows the Disaster Assessment Methodology developed by the Economic Commission for Latin America and the Caribbean. The ECLAC methodology allows standardized data collection and analysis on a sectoral basis; therefore, the same criteria are applied to every sector under study. In this regard, the following concepts are used in the assessment ${ }^{6}$ :

a. Effects: damage, loss and additional cost.

b. Impacts: consequences of the effects on macroeconomic variables, such as GDP, public finance or balance of payments.

c. Damage: the effect the disaster has on the assets of each sector, expressed in monetary terms. These occur during the event giving rise to the disaster. Depending on the sector, assets may include buildings, machinery, equipment, means of transportation, furnishings, roads, ports, stocks of final and semi-finished goods, among others.

d. Loss: goods that go unproduced and services that go unprovided during a period running from the time the disaster occurs until full recovery and reconstruction is achieved.

e. Additional costs: outlays required to produce goods and provide services as a result of the disaster. These represent a response by both the public and the private sectors, and may take the form of additional spending or a recomposition of spending.

Based on the information gathered during field visits and interviews, the social sector analysis focuses on affected population, housing, health and education. The infrastructure sector comprises transportation, telecommunications, power, and water and sanitation. The productive sectors analysed are tourism and fisheries. Additionally, the report includes a crosscutting assessment of the effects suffered by the environmental sector.

In order to quantify the economic damages, losses, and additional costs associated with Hurricane Matthew, the Ministry of Finance of the government of The Bahamas has requested this report from the Inter-American Development Bank (IDB). The IDB, in turn, requested technical assis- 
tance from the United Nations Economic Commission for Latin America (UN-ECLAC), which has assembled this report using its Damage and Loss Assessment (DALA) methodology. In conducting this assessment, ECLAC enlisted the participation of sister agencies such as the Pan American Health Organisation (PAHO) and the Food and Agriculture Organisation (UN-FAO). The ECLAC DALA methodology, which has been used to evaluate the impacts of at least 95 disasters since 1972, categorizes the financial impacts of the hurricane into four sectors-social, infrastructure, productive and environment.

The assessment team visited The Bahamas from 23 to 29 October to collect data and obtain an overview of the effects of the hurricane in the country. Between 23 and 25 October, team members visited the most affected areas in Grand Bahamas. On the afternoon or 25 October, they visited the most affected areas in New Providence. On 26 October, some of them went to Andros and others to the Berry Islands. In addition, the assessment team held meetings and interviews with representatives from government agencies responsible for each sector under analysis.

The assessment was carried out using official data provided by the government, interviews with the private sector, and observations from the field visits. However, as detailed in each pertinent sector, the main limitation of the assessment was access to information, either due to unavailability during the assessment or because it is not yet collected or produced in the country. This limitation was overcome by creating reasonable assumptions where data was unavailable. Both official information and assumptions were used to estimate the effects of the hurricane and are presented in each section. 


\section{Description of the event}

The storm that was to become Hurricane Matthew emerged on 22 September as a tropical wave off the coast of Africa. After crossing the Atlantic Ocean, the storm became organised and rapidly strengthened as it entered the Caribbean Sea. The United States National Hurricane Centre recognized it as a tropical storm at 15:00 UTC on Monday 28 September. At that time, the centre of the storm was located 35 miles $(56 \mathrm{~km})$ southeast of Saint Lucia, and instruments on a Hurricane Hunter airplane measured surface winds of $58 \mathrm{mph}(93 \mathrm{~km} / \mathrm{h})$, with gusts at altitude reaching hurricane strength (Figure 1).

Figure 1- Wind swath of Hurricane Matthew

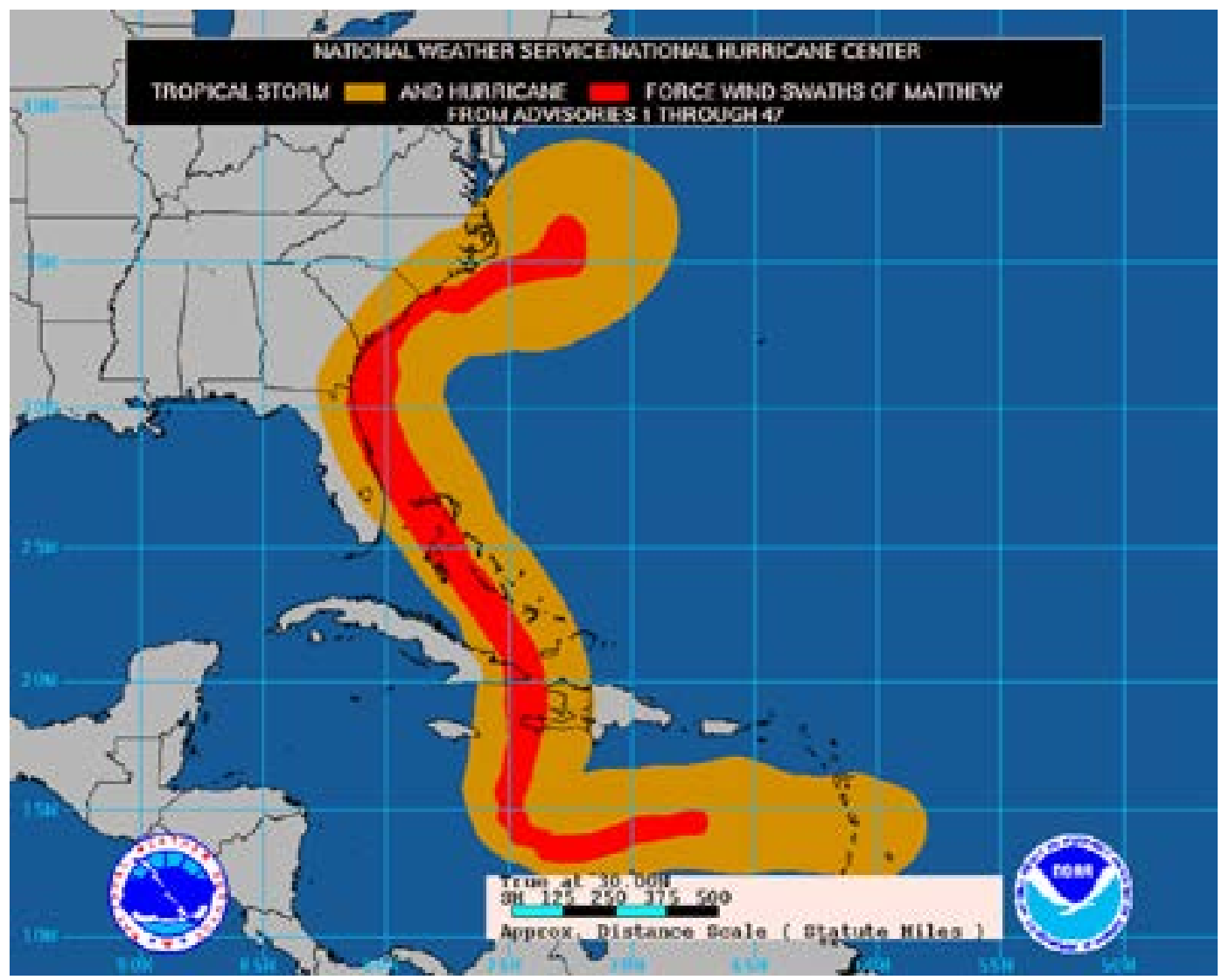

Source: United States National Hurricane Centre

Tropical Storm Matthew tracked westward between the islands of Saint Lucia and Saint Vincent, gaining power and becoming increasingly organised as it traversed an area of warm water and low wind-shear. It reached Category 1 intensity, with wind speeds of $75 \mathrm{mph}(121 \mathrm{~km} / \mathrm{h})$, on 29 September. Then it explosively intensified from 30 September to 1 October, becoming a Category 5 hurricane with winds above $160 \mathrm{mph}$ $(257 \mathrm{~km} / \mathrm{h})$. Off the coast of Colombia at the time-and causing intense floods in that country-Matthew became the southernmost Category 5 hurricane ever recorded in the Atlantic Basin. 
At about 23:00 UTC on 1 October, The Bahamas' National Emergency Management Agency (NEMA) issued the first of many hurricane alerts for the entire country. Alerts were distributed to the public through traditional media channels and social media. NEMA also sent SMS-based text messages to cell phone service subscribers throughout the country, working with Bahamas Telecommunications Company (BTC).

Hurricane Matthew's wind speeds diminished slightly on 1 October with the initiation of an eyewall replacement cycle. This reduced the storm's Saffir-Simpson scale classification to Category 4. The storm's westward trajectory then slowed abruptly, and it began turning north.

With this turn, Jamaica was considered at high risk of landfall and emergency preparations were undertaken there. However, Hurricane Matthew took a more easterly course than expected, missing Jamaica and instead crossing over the western portion of Haiti's southern peninsula on Monday 3 October. In Haiti, high winds and torrential rains caused widespread destruction of homes and other structures built to a very low standard of construction. Flooding was exacerbated by steep terrain. As a result of this high level of damage to populated areas, more than 1,000 Haitians were killed.

The storm proceeded north, crossing extreme eastern Cuba during the night of 4 October. The city of Baracoa, close to the centre-path of the storm, suffered intense damage as a result of storm surge, but no lives were lost, in part due to an effective scheme for public warning, evacuation, and sheltering.

Matthew's passage over the mountains of Cuba disrupted the storm somewhat, reducing winds to about $125 \mathrm{mph}(200 \mathrm{~km} / \mathrm{h})$ by the time it re-emerged over the Atlantic Ocean on Wednesday morning, 5 October. At this point, it was a Category 3 storm, but it again intensified as it advanced north-westerly, at approximately $11 \mathrm{mph}(18 \mathrm{~km} / \mathrm{h})$, in parallel to the long axis of The Bahamas island chain (Figure 2).

At this point, the entirety of The Bahamas was under a hurricane warning, and shelters were being opened throughout the islands.

Compared to Hurricane Joaquin-a more erratic and rapidly developing storm that had caught some Bahamian islands by surprise-Hurricane Matthew approached more slowly. This allowed more time for alerting the public and helped ensure that people received timely notice of the necessity for emergency storm preparations. These actions included boarding up windows and evacuating people from vulnerable locations and sheltering them in schools and public buildings.

On Facebook, NEMA published regular, current descriptions of the location, movement, strength, and size of the storm. An example is this excerpt from a NEMA posting at about 20:00 UTC on 5 October: 


\begin{abstract}
...AT 2PM, THE CENTER OF HURRICANE MATTHEW WAS LOCATED NEAR LATITUDE 22.1 DEGREES NORTH AND LONGITUDE 75.3 DEGREES WEST OR ABOUT 40 MILES SOUTHEAST OF DUNCAN TOWN, RAGGED ISLAND, 70 MILES WEST OF SALINA POINT, ACKLINS, 70 MILES SOUTH-SOUTHWEST OF DEADMAN'S CAY LONG ISLAND, 95 MILES SOUTH-SOUTHEAST OF GEORGE TOWN EXUMA, 235 MILES SOUTHEAST OF FRESH CREEK ANDROS, 380 MILES SOUTHEAST OF WEST END, GRAND BAHAMA AND 240 MILES SOUTHEAST OF NEW PROVIDENCE.
\end{abstract}

MATTHEW IS MOVING TOWARD THE NORTHWEST NEAR 12 MPH, AND THIS MOTION IS EXPECTED TO CONTINUE DURING THE NEXT 24 TO 48 HOURS. ON THIS TRACK THE EYE OF MATTHEW WILL BE MOVING VERY NEAR TO GEORGETOWN, EXUMA BY 8PM TONIGHT,

ACROSS THE BAHAMAS THROUGH THURSDAY, AND IS EXPECTED TO BE VERY NEAR THE EAST COAST OF FLORIDA BY THURSDAY EVENING.

MAXIMUM SUSTAINED WINDS ARE NEAR 120 MILES PER HOUR WITH HIGHER GUSTS. MATTHEW IS A DANGEROUS CATEGORY 3 HURRICANE ON THE SAFFIR-SIMPSON HURRICANE WIND SCALE. SOME STRENGTHENING IS FORECAST DURING THE NEXT COUPLE OF DAYS, AND MATTHEW IS EXPECTED TO REMAIN AT CATEGORY 3 OR STRONGER WHILE IT MOVES THROUGH THE BAHAMAS.

HURRICANE FORCE WINDS EXTEND OUTWARD UP TO 45 MILES FROM THE CENTER AND TROPICAL STORM FORCE WINDS EXTEND OUTWARD UP TO 175 MILES FROM THE CENTER....

NEMA Alert \#32 20:00 UTC 5 October

The storm continued north-westerly, passing through the latitudes of Acklins, Crooked Island, Long Island, Rum Cay and San Salvador, which were the islands most impacted by Hurricane Joaquin in 2015. However, Matthew's path was far enough west to spare these islands significant damage, despite tropical storm-force winds. In Acklins, the storm caused no major flooding although it blew shingles off some roofs and downed some power lines. Islands in the eastern part of the chain-such as Cat Island, Eleuthera and Abaco-were similarly affected. In the Exumas, there were reports of shingles torn off roofs, broken windows, downed power lines, and damage to docks, boats and a water tower.

The eye passed west of the Exumas at about 1:00 UTC on 6 October, still somewhat disorganised from having crossed over Cuba. Matthew was now a Category 3 hurricane with winds measured at $115 \mathrm{mph}(185 \mathrm{~km} / \mathrm{h})$. By sunrise on 6 October, however, the eye had fully reformed and Matthew had intensified to Category 4. It passed through the channel between the islands of Andros and New Providence, with the western eyewall of the storm transiting the far eastern portion of New Providence. The city of Nassau, the most populous part of the country, located in north-western New Providence island, recorded sustained wind speeds of $85 \mathrm{mph}$ (137 km/h). The storm's low barometric pressure, combined with winds coming from the south, built a 9-foot $(2.7-\mathrm{m})$ storm surge and drove seawater up to one-third of a mile $(500 \mathrm{~m})$ inland at San Andreas, on the southern shore. Other communities on the southern shore were similarly affected. Throughout New Providence, seawalls were damaged, trees uprooted, sections of roof blown from houses, and roads flooded. There were widespread failures in the power grid. 
Across the channel, on the western side of the storm, roofs and vegetation were damaged in the central part of Andros? Island. Farther north, the damage was worse. The telecommunications tower in North Andros partially collapsed, cutting off cellular service in that part of the island and severing the area's primary communications link to Nassau. Many trees were blown over, some landing on buildings or power and telecommunications lines. Wind speeds were said to have reached $140 \mathrm{mph}$ (225 $\mathrm{km} / \mathrm{h})$, and a number of tornados were spawned.

Figure 2- Path of Hurricane Matthew in The Bahamas

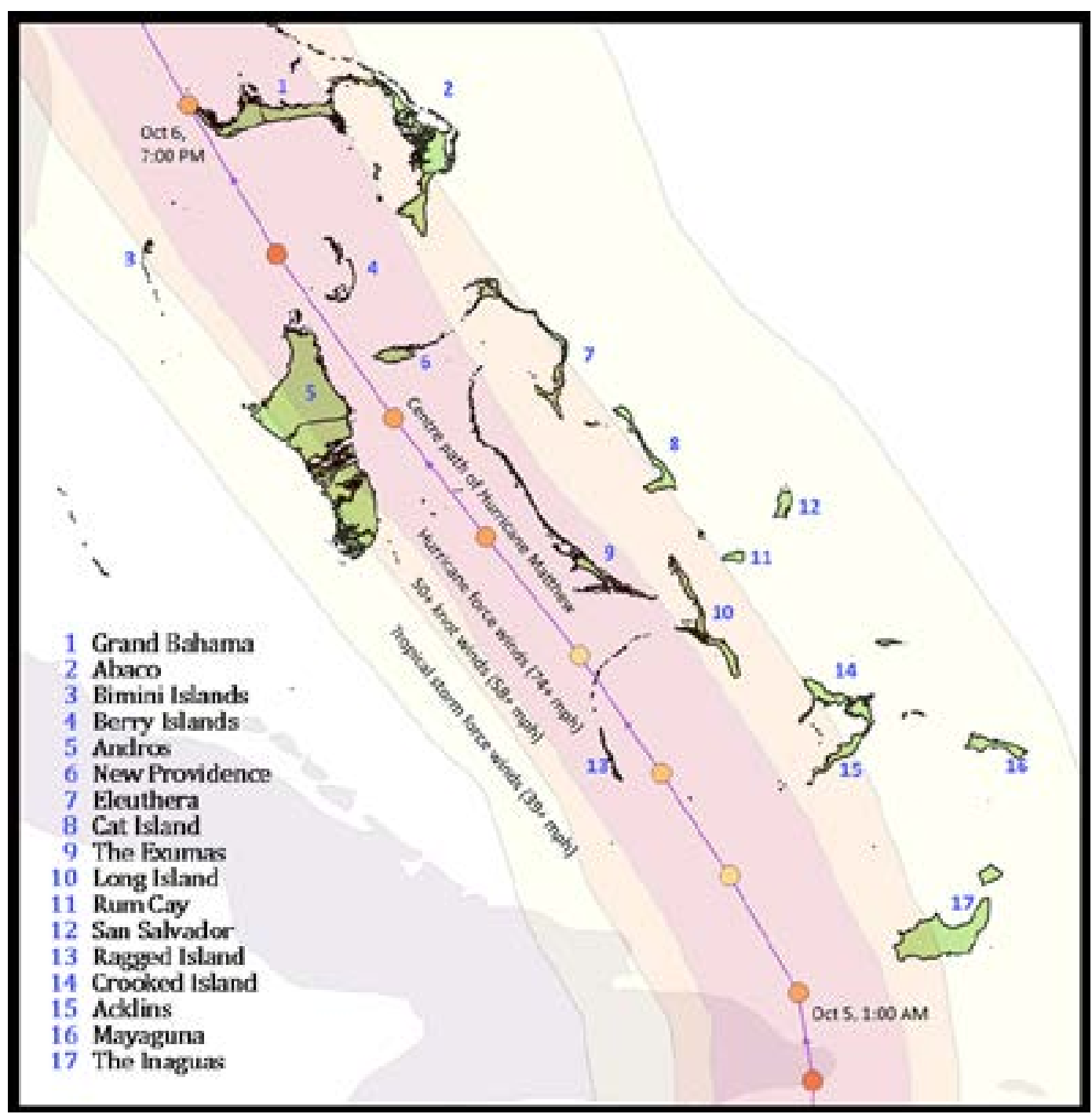

Source: United States National Hurricane Centre 
The community of Lowe Sound near the northern tip of Andros experienced heavy winds that came first from the east and then the north. As the wind shifted-around 14:00 UTC on 6 October-it brought a heavy and rapid storm surge, which some locals described as being like a tsuna$\mathrm{mi}$. The surge reached 12 feet $(3.7 \mathrm{~m})$ high and advanced about 3 miles $(5 \mathrm{~km})$ inland. It retreated within 45 minutes, leaving devastated buildings and large areas of standing water. The town's fish purchasing facility was destroyed. A liquor wholesaler had $\$ 200,000$ worth of inventory washed away. Two seaside churches withstood major damages. Graves were torn from the town cemetery, leaving caskets and human remains exposed among the debris. A 75-year-old man died of a heart attack during the storm, the only fatality associated with Hurricane Matthew in The Bahamas.

After passing Andros, Matthew continued past the Berry Islands and the western end of Grand Bahama. On the southern coast of Grand Bahamas, storm surges reached up to one-third of a mile $(0.5 \mathrm{~km})$ from the shoreline. The community of West End, exposed to the ocean on the north, saw extensive damage to housing and docks because of storm surge and high winds. The strongest parts of the storm passed somewhat west of Freeport, the island's largest city, but high winds still felled trees and damaged roofs and power infrastructure.

After leaving the waters of The Bahamas in the early hours of 7 October, Matthew tracked roughly parallel to the east coast of the United States, passing near central and northern Florida and Georgia before making landfall in South Carolina on the morning of 8 October, moving through eastern North Carolina and then heading out to sea on 9 October. As the storm centre passed over southern North Carolina, its northern portion dropped massive volumes of rain across the eastern section of the state, which led to historic flooding. There were 49 deaths in the United States attributed to Hurricane Matthew.

Extensive damage in the United States limited the availability of U.S. resources for assisting recovery efforts in The Bahamas. For example, high demand for tarpaulins to cover damaged roofs in affected states led to a tarp shortage on the East Coast. Tarps for Grand Bahama had to be sourced from California. Additionally, American utility repair crews could not help restore power and telecommunications services in The Bahamas until they had addressed priorities in the United States. 



\section{Affected population}

\section{Introduction}

The effects of Hurricane Matthew on the population of The Bahamas were moderate. Aside from one man who had a heart attack during the storm, there were no deaths and no reported injuries. Damage to the housing sector temporarily decreased quality of life due to disruptions to services such as health, electricity, telecommunications and transport. The hurricane damaged approximately 2,630 dwellings, directly affecting about 8,931 people. The most severe housing-sector damage was sustained in 917 dwellings that accommodated about 3,093 inhabitants.

Reports indicate that 3,221 people were sheltered in 50 facilities throughout the four affected islands analysed on this report during and after the storm. ${ }^{7}$ Most families had short stays in shelters.

About 13,354 students and more than 1,000 teachers were affected by the suspension of classes. In several islands the school closures started before the hurricane's arrival and continued until 25 October.

Electrical power was the public service most affected by the hurricane. An estimated 127,000 consumers were left without electricity after its passage. In Grand Bahama, some schools reported to the assessment team that lack of electricity was the main obstacle to reopening. Lack of power also affected the drinking water sector.

With regard to the livelihoods of the affected population, the fact that in the fishing sector the small producers were the ones who suffered most as a result of this hurricane. Based on the estimation of the macro-economic impact, a loss of 13.7 million dollars is estimated in the remunerations of the workers of this sector.

The information presented in this section was obtained from reports from the 2010 Census, as well as from reports from and interviews with the Department of Statistics, the Ministry of Social Services and the Ministry of Finance.

\section{Affected islands}

Hurricane Matthew affected primarily four islands in The Bahamas: Andros, Berry Islands, Grand Bahama and New Providence. They have about 327,828 inhabitants, ${ }^{8}$ about 88 per cent of the country's total. ${ }^{9}$ However, not all were directly affected by the hurricane, as its intensity varied among areas and settlements.

7. By that time, on other Bahamian islands, there were 2,019 people in 70 shelters. The list of islands includes Harbour Islands, Eleuthera, Cat Island, Bimini, Mayaguana, Inagua, San Salvador, Acklins, Crooked Island, Exuma, Rum Cay, and Abaco. The islands with the most people in shelters were Abaco, 30.6 per cent, and Eleuthera, 26.8 per cent.

8. See Department of Statistics (2015).

9. In this report we are taking into account projections for the assumption B (medium), see Department of Statistics of The Bahamas (2015) 
According to the Ministry of Social Services, the most affected areas of each island are the following:

- Andros: North district including Lowe Sound, Conch Sound, Mastic Point and Nicholls Town.

- Berry Islands: Bullocks Harbour and Chub Cay.

- Grand Bahama: West End, Eight Mile Rock, Pinder's Point, Lewis Yard, Hunters, Mack Town, East End and Freeport.

- New Providence: Southern Shores, Yamacraw, Elizabeth, Sea Breeze, South Beach, Coral Harbour and Adelaide in addition to the inner city of Nassau.

\section{Demographics}

Andros, Berry Islands, Grand Bahama and New Providence have approximately 327,828 inhabitants, which accounts for 87.8 per cent of the country's population. The distribution of the population among these islands follows: Andros 2.2 per cent, Berry Islands 0.3 per cent, Grand Bahama 16.6 per cent and New Providence 71.2 per cent.

Andros is the largest island of The Bahamas with an area of 2,300 square miles $(5,960 \mathrm{~km} 2)$. Berry Islands is the smallest at 30.1 square miles (78 $\mathrm{km} 2$ ). New Providence has the highest population density, with 3,326 inhabitants per square mile (1,294/km2), 30 times greater in density than Grand Bahama (Table 4). New Providence is more than 1,000 times higher in density than Andros, which, at 3.1 inhabitants per square mile (1.2/ $\mathrm{km} 2$ ), has The Bahamas' lowest population density.

Over the last five decades, the population dynamics of these islands have differed. Grand Bahama and New Providence have had steady population growth. Since the 1970s, their annual growth rates of have been 1.69 per cent and 2.19 per cent respectively. By contrast, the population of Andros has declined since 1970.

The Bahamas population projection for 2016 is 373,480 inhabitants, of whom 48.3 per cent are male and 51.7 per cent are female. Male/female ratio is similar to this in Grand Bahama and New Providence. However, males make up 50.3 per cent in Andros and 57.1 per cent in Berry islands. About 24.1 per cent of the population of The Bahamas is under 15 years of age, including 7.4 per cent who are less than 5 years old. The productive group, between 15 and 64 years, accounts for 69.2 per cent. The population over 65 years is 6.7 per cent. The dependency ratio ${ }^{10}$ for the country is 43.5 ; for Andros it is 66.5 per cent. 
Table 4- Demographics of affected islands

\begin{tabular}{|l|r|r|r|r|}
\hline & \multicolumn{1}{|c|}{$\begin{array}{c}\text { New } \\
\text { Providence }\end{array}$} & $\begin{array}{c}\text { Grand } \\
\text { Bahama }\end{array}$ & \multicolumn{1}{c|}{$\begin{array}{c}\text { Andros } \\
\text { Berry } \\
\text { Islands }\end{array}$} \\
\hline Population (thousands) & 266.1 & 54.528 & 7.2 & 72.3 \\
\hline Female (per cent) & 48.1 & 48.7 & 50.3 & 57.1 \\
\hline Male (per cent) & 51.9 & 51.3 & 49.7 & 42.9 \\
\hline Density (persons per sq. mile) & $3,326.3$ & 102.9 & 3.1 & 28.5 \\
\hline Distribution by age (per cent)- & & & & \\
\hline 0-4 years & 8.4 & 8.8 & 8.6 & n.a. \\
\hline 5-14 years & 16.7 & 18.3 & 22.0 & n.a. \\
\hline 15-64 years & 69.0 & 66.9 & 59.3 & n.a. \\
\hline +65 years & 6.0 & 6.0 & 10.1 & n.a. \\
\hline Average household size ${ }^{\text {a }}$ & 3.5 & 3.4 & 3.2 & 2.4 \\
\hline
\end{tabular}

Source: Bahamas Census, 2010

a/ This was estimated using data from the 2010 Census of The Bahamas

According to the 2010 Census $^{11}$, there are 10,138 people with disabilities $^{12}$ in The Bahamas. Of these, 85.2 per cent live on the affected islands. In all these islands, more males than women have disabilities. In the Berry Islands, 76.5 per cent of the people with disabilities are males. Andros is the only affected island where the percentage of persons with disabilities (3.2 per cent) is greater than the national average (1.93 per cent).

\section{Affected population}

This section defines the primary affected population as persons who suffered direct effects of the hurricane, such as having their homes flooded, and secondary affected population as people suffered indirect effects, such as being unable to attend school because its electricity was lost. ${ }^{13}$

The primary affected population consists of persons who suffered physical or health effects or suffered damage to their assets such as housing. Fortunately, neither deaths nor injuries were reported in The Bahamas after Hurricane Matthew struck.

The hurricane forced some inhabitants to evacuate before it arrived. According to the Ministry of Social Services, 28 people were evacuated from the Berry Islands; 44 Acklins families and three Long Island families also were evacuated. ${ }^{14}$ Evacuation was voluntary, and these people all were brought to Nassau.

Shelters were located in churches, schools, community centres, gymnasiums, Salvation Army facilities and Administrator's Complexes. For The Bahamas, it is estimated that 5,240 people were temporarily sheltered. 
Table 5 shows the numbers of people and shelters in Andros, Berry Islands, Grand Bahama and New Providence. It is estimated that 3,221 were in shelters in those islands.

In New Providence, 82 per cent of shelters were churches, and they housed 84.4 per cent of the people sheltered on that island. On Grand Bahama, those figures were 36 per cent and 41.2 per cent, respectively. For Andros, those figures were 53 per cent and 55 per cent, respectively. In Berry Island, the only shelter is a church.

The Ministry of Social Services informed the assessment team that there were no reports of abuse or violence in the shelters.

Buildings used as shelters were not built for this purpose. On the smaller islands, community centres can play this role. Ideally, only a few schools should be used as shelters so that schools can reopen as soon as possible.

The country was relatively well prepared, as indicated by the facts that there were no deaths or major injuries directly caused by the hurricane and that relatively few people needed shelters. It is necessary to emphasize that a "culture of hurricanes" in The Bahamas encourages inhabitants to take protective measures beforehand. This should continue to deepen, because reduction of disaster risk begins with education on these issues as early as primary school. In addition, information regarding the hurricane was transmitted to the population in a timely manner.

Table 5- Shelters by island and population in shelters

\begin{tabular}{|c|c|c|}
\hline District & Number of shelters & Population in shelters \\
\hline \multicolumn{3}{|l|}{ Affected islands- } \\
\hline Andros & 19 & 307 \\
\hline Berry Islands & 1 & 28 \\
\hline Grand Bahama & 11 & 813 \\
\hline New Providence & 22 & 2,073 \\
\hline Total $^{b}$ & 53 & 3,221 \\
\hline \multicolumn{3}{|l|}{ Other islands } \\
\hline Abaco & 12 & 618 \\
\hline Acklins & 3 & 46 \\
\hline Bimini & 4 & 117 \\
\hline Cat Island & 8 & 130 \\
\hline Crooked & 4 & 47 \\
\hline Eleuthera & 25 & 542 \\
\hline Exuma & 1 & 123 \\
\hline Harbour Island & 3 & 57 \\
\hline Inagua & 1 & 45 \\
\hline Long Island & 1 & 125 \\
\hline Mayaguana & 3 & 61 \\
\hline Ragged Island & 1 & 11 \\
\hline Rum Cay & 1 & 2 \\
\hline San Salvador & 3 & 95 \\
\hline Total & 70 & 2,019 \\
\hline
\end{tabular}


Although there were apparently no deaths or serious injuries, some measures can be taken to reduce future risks. One positive aspect is that several evacuations were made before arrival of the hurricane. It is important to know the protocol followed-if any-during an evacuation, and to evaluate that protocol. If a protocol was not followed, one should be established and must be practiced.

Another factor that must be considered is the quality of shelters. During the hurricane, three shelters in New Providence were damaged. Buildings intended for use as shelters must be evaluated structurally to ensure that they can withstand hurricanes.

Another factor to consider in shelter procedures is the establishment of a protocol for collecting information about the people being sheltered. For example, except for New Providence, the assessment team was not provided with information about the sex and age of the people who were sheltered. For New Providence, this information was available for 54.5 per cent of the shelters. For no island was information provided on the number of people with disabilities.

Regarding access to services, 20,000 customers faced average power outages of three weeks in Grand Bahama, and in the other three islands, 107,000 customers had an average service loss of one week.

There was a shelter designed to house persons with special needs. Group home patients with developmental and intellectual disabilities were housed in Sandilands Rehabilitation Centre. Some senior citizens were kept safe in various homes throughout New Providence.

After the hurricane, vulnerable populations were identified. Mental health teams were dispatched throughout the islands to provide psychological and counselling services to residents. In Grand Bahama, a psychological team offered counselling sessions to adults and children. No specific information about these relief efforts was provided.

According to the Ministry of Finance, the government of The Bahamas, through its various institutions, has destined $\$ 7$ million for the attention of the emergency and relief efforts. 



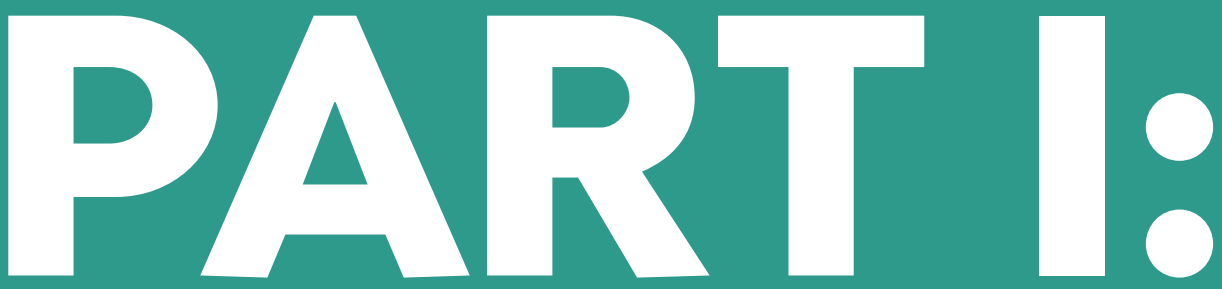

ASSESSMENT OF EFFECTS

AND IMPACTS 


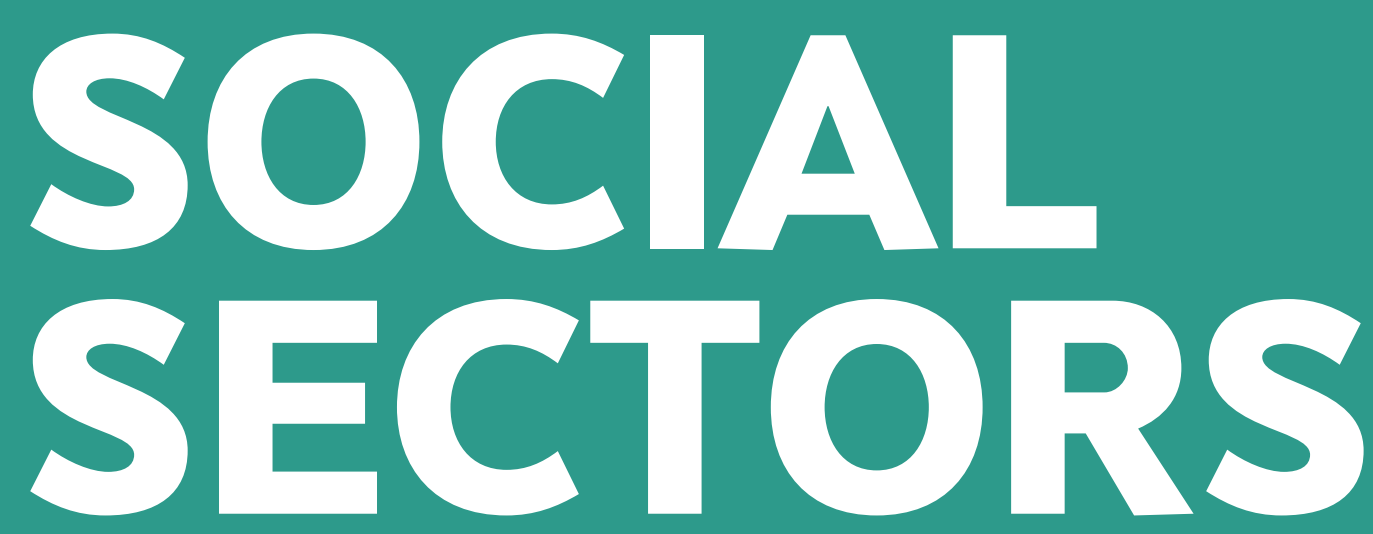




\section{Housing}

\section{Introduction}

Housing is one of the sectors most severely affected by Hurricane Matthew. Some low-lying settlements along or near coastlines suffered heavy damage as a result of storm surge, and houses throughout the islands suffered wind damage to roofs, water damage as a result of rain intrusion, or were impacted by falling trees and flying debris.

Approximately 87 per cent of households nationwide are located in the New Providence, Grand Bahama, Andros, and the Berry Islands,

Damage to the housing sector on New Providence, Grand Bahama, Andros, and the Berry Islands is estimated at \$200.1 million. The ECLAC team calculates losses of $\$ 10.9$ million. Additional costs are estimated at \$11.2 million. This consisted of removing rubble, cleaning out destroyed dwellings and renting equipment.

The information for this section comes from fieldwork observation and interviews and from official institutions including Ministry of Works and Urban Development, Ministry of Environment and Housing, Central Bank of Bahamas, Department of Statistics of the government of Bahamas, and the Bahamas Insurance Association.

The damage estimate considers only dwellings assessed by the ECLAC Team and the responsible ministries for each affected island. It does not consider unreported homes that sustained minor or moderate damage. The information analysed for this assessment has limitations, specifically in regards to levels of damage, type of construction and location.

\section{Baseline information}

According to the 2010 Census, there are 70,222 occupied dwellings in New Providence, 15,140 in Grand Bahama, 2,373 in Andros and 342 in Berry Islands. Nationally, the average household size is 3.4 people per household.

During field visits to the affected islands, the ECLAC team observed that most homes are built of concrete block, with poured concrete slabs and concrete foundations. The most common roofing materials are plywood and asphalt shingles. Constructions meet very strict building codes. This standard of building construction includes approximately 75 per cent of the total houses in all the islands. Wood and timber constructions are in use as well. Most of the inspected wooden houses tend to be older than, and inferior to those made of reinforced masonry. 
Abandoned and unfinished constructions are severely damaged as the result of Joaquin or other previous events. The total number of completed construction in the second quarter of 2016 showed an increase of 29 units, 124 units in the first quarter of 2016 compared to 153 in the second quarter. This increase was also reflected in the value, which increased from approximately \$44 million in the first quarter of 2016 to approximately $\$ 58$ million in the second quarter.

In The Bahamas as elsewhere, construction costs vary depending on location, terrain, site topography, building design, materials and quality of finish. In the Family Islands, construction costs are about 30 per cent higher than in New Providence. The cost of transporting building materials to the Family Islands by boat contributes to a situation in which many contractors and owners are building below required standards. In Andros, a high percentage of houses are built of timber and plywood, due to lack of materials and aggregates for masonry construction.

Building standards in The Bahamas are higher than in practically all United States hurricane zones including the very tough standards of South Florida. The present code was issued in 2003, and its use is mandatory for design and construction of all buildings including private dwellings and public buildings. However, the lack of qualified inspectors to conduct structural inspections in more remote areas contributes to substandard construction and structural deficiencies. This is likely to contribute to major damage in future events.

The government declared an exigency order in the wake of Hurricane Matthew that will last for 180 days, effective from 7 October 2016 to 4 April 2017. The order allows residents affected by the storm to import certain items into the country duty and tax-free. Tax-exempt items include building materials, electrical fixtures and materials, plumbing fixtures and materials, household furniture, furnishing and appliances, bottled water, generators and motor vehicles. The exigency order covers only New Providence, Grand Bahama, the Berry Islands, and North and Central Andros. The order states that "Customs duty and VAT exemption will be granted to registered charitable organizations, and individuals whose loss by Hurricane Matthew has been verified by NEMA. All other authorized donations will be deemed a gift to the government and will be received and distributed by NEMA."

\section{Damage}

The costs presented in this section are estimates based on official sources in the weeks after the event and field inspections to the islands. Of the 2,630 dwellings affected on the four islands under analysis, the ECLAC team estimates that 4 per cent were destroyed, 31 per cent have significant structural damage, 23 per cent have minor damage and 42 per cent have insignificant damage. There were more houses damaged than were included in the Caribbean Disaster Emergency Management Agency (CDEMA) assessments. Information that the ECLAC assessment team 
gathered in a meeting with The Bahamas Insurance Association allow us to adjust estimates of damage of housing including equipment such as vehicles. ${ }^{15}$ This results in a total estimated damage of $\$ 200.1$ million (Table 6).

Table 6- Estimated damage to dwellings by island

\begin{tabular}{|c|c|}
\hline Island & Damage \\
\hline New Providence & $36,227,121$ \\
\hline Grand Bahama & $152,411,061$ \\
\hline Andros & $10,706,582$ \\
\hline Berry Islands & 743,157 \\
\hline Total & $\$ 200,087,921$ \\
\hline
\end{tabular}

Source: Elaborated with data provided by the Caribbean Disaster Emergency Management Agency (CDEMA), The Bahamas Insurance Association and local authorities.

Most of the damage sustained by the structures was to roofs and ceilings due to strong winds, and subsequent water damage to interiors including furnishings, appliances and other equipment and property.

The ECLAC team considered two factors in estimating the damage to dwellings, shown in Table 7:

1. Average house value, based on average house size, building class and consideration of outer walls and roofing materials.

2. Level of damage assigned to each house:

a. Level 1, 10 per cent: No significant damage. Structure is usable and can be occupied. Repairs required are minimal.

b. Level 2, 25 per cent: Minor damage. Structure is usable and can be occupied after urgent temporary measures are taken. Assistance will probably be required for repairs.

c. Level 3, 60 per cent: Major damage. Structure is not usable and cannot be occupied until after repairs are made.

d. Level 4, 100 per cent: Destroyed. Structure is not usable and cannot be repaired. Must be rebuilt.)

15. Hurricanes deductibles were designed to increase the risk of hurricanes and to the urban and population development of the coastal regions, so that the private insurer can continue to offer part of the risk with the insurer. These deductibles only apply to damages caused by these disasters and typically range from one per cent to five per cent of the properties insured value. In Bahamas the deductibles for housing is two per cent. The percentage of the houses and buildings insured against cyclones in The Bahamas is minimal, despite the high risk rating of the area. Although insurance companies consider The Bahamas as a "high vulnerability" zone because of hurricanes, the highest risk range, the index of insured houses against the effects of this phenomenon is very small. 
Table 7- Summary of levels of damage to housing by district, as of 29 October 2016

\begin{tabular}{|l|r|r|r|r|r|}
\multicolumn{1}{c}{ District } & \multicolumn{2}{c}{ Level 1 } & \multicolumn{2}{c|}{ Level 2 } & \multicolumn{2}{c|}{ Level 3 } & Level 4 & \multicolumn{2}{c|}{ Total } \\
\hline Andros & - & - & 100 & 30 & 130 \\
\hline Berry Islands & 25 & - & 3 & - & 28 \\
\hline Grand Bahama & 800 & 495 & 667 & 78 & 2,040 \\
\hline New Providence & 283 & 110 & 39 & - & 432 \\
\hline \multicolumn{1}{|c|}{ Total } & $\mathbf{1 , 1 0 8}$ & $\mathbf{1 1 0}$ & $\mathbf{8 0 9}$ & $\mathbf{1 0 8}$ & $\mathbf{2 , 6 3 0}$ \\
\hline
\end{tabular}

Source: extrapolated from data provided by the CDEMA and local authorities

During field visits to the affected islands, the team recognized many problems related to lack of consistent, quality construction - especially regarding roofing. For example, in some cases, nailing installation was deficient. For building codes in most hurricane-prone areas, the minimum nailing pattern specifies 21/2-inch smooth-shank nails spaced 6 inches $(15 \mathrm{~cm})$ along all roof-framing members. This should be the minimum acceptable standard, and is one example of a need for new structural regulations for reconstruction.

\section{Andros}

North Andros was severely impacted by hurricane winds and flooding from storm surges of 9 to 12 feet $(2.7$ to $3.7 \mathrm{~m}$ ), especially in Lowe Sound and Conch Sound settlements, resulting in significant damages to the housing sector.

During the field visit, the team observed on several occasions that beach sand was being used for the preparation of concrete. Salts adsorbed to the sand reduce the durability of reinforced concrete structures. In plain concrete or mortar for plaster, this may be less detrimental. However, beach sand has other attributes that limit its desirability, including aggregate shape and size. Beach sand tends to be very fine and rounded, which is not advisable for making mixes.

Another ill-advised practice observed was the used of conch shells in concrete mixes and as the main filler material for concrete slabs (Figure 3). These shells are abundant and inexpensive, making them popular for use in filling and preparing concrete, instead of a more appropriate aggregate. However, when economy demands, conch shells are used, and their use is adequate so long as this complies with respective codes of practice. 
Figure 3- Conch shells used as an aggregate in concrete slab destroyed by storm surge in Lowe Sound
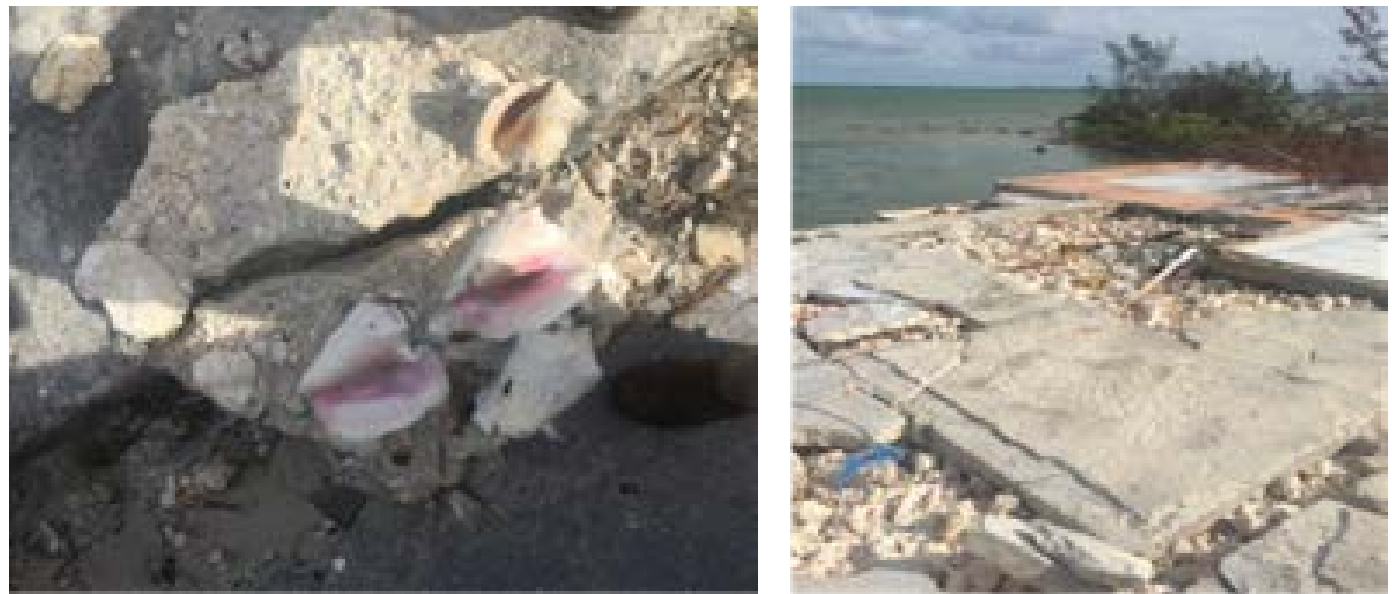

Source: Assessment team

Houses in Lowe Sound and Conch Sound that were built at the shoreline or within about 66 feet $(20 \mathrm{~m})$ inland were destroyed by storm surges and flooding. Location and structural deficiencies are the major causes why these settlements were severely affected. Additionally, construction materials and building processes in those areas cause many deficiencies in houses and are unsuitable. Housing vulnerability to the disaster was high for the following reasons:

1. Lack of technical supervision by municipalities during construction.

2. Inefficient structural components and construction deficiencies.

3. Lack of proper maintenance to dwellings, especially to roof structures.

\section{Grand Bahama}

In Grand Bahama, damage is concentrated in two locations: West End and Eight Mile Rock. Most of the damage resulted from strong winds and storm surges, as illustrated in Figure 4. Strong winds caused widespread damage to roofs, walls and windows. Subsequently, damaged roofs allowed water penetration affecting ceilings, walls, furniture and equipment, all due to flooding. Additionally, homes were damaged by storm surges. Most settlements near bodies of water received severe flooding of up to 9 feet $(2.7 \mathrm{~m})$. In all, 2,040 dwellings were damaged by winds, surges, and flooding. 
During the field visit, the team observed roof damage and shingle losses in approximately 72 per cent of the total dwellings in the islands under analysis. The storm surge up to 9 feet $(2.7 \mathrm{~m})$ also damaged fences and main gates of properties along the coastline. Water from the storm surge affected properties at least one-half mile $(0.8 \mathrm{~km})$ inland.

Strong winds damaged power lines and transformers, interrupting the electrical service for at least several weeks in most parts of the island, and resulting in interruption in the water supply for most of the dwellings effected.

Figure 4- Photos showing front walls, buildings and other major damage caused by storm winds and surge flooding in West End
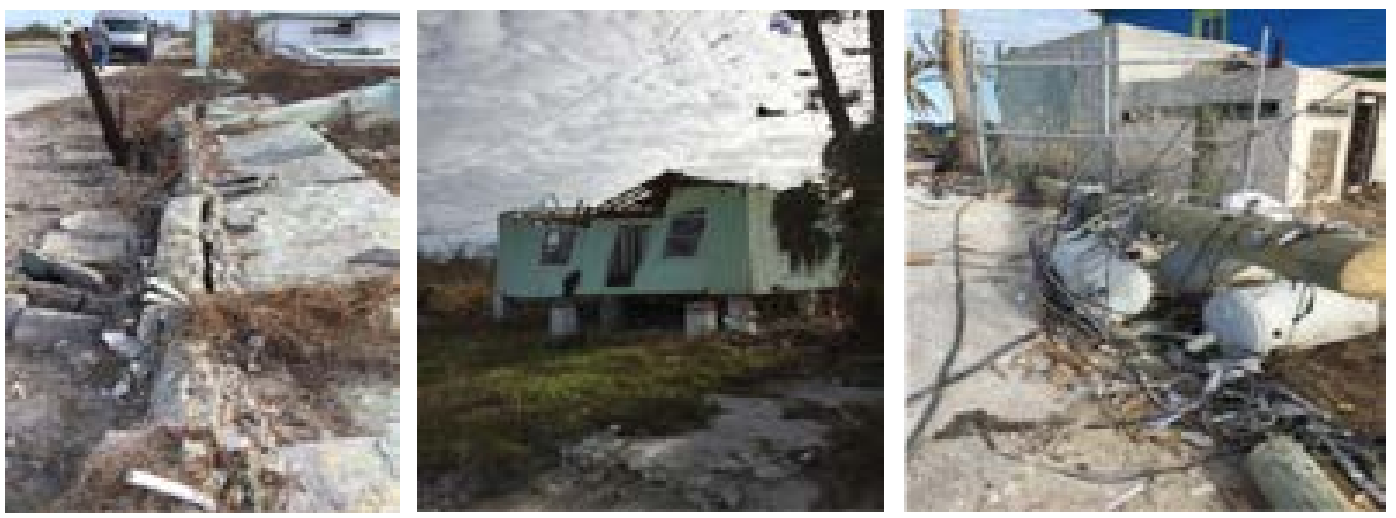

Source: Assessment team

\section{New Providence}

New Providence is by far most densely populated island of The Bahamas. According to the 2010 Census, its 246,329 residents make up 73 per cent of the country's total population. Population density is 3,079 per square mile $(1,189 / \mathrm{km} 2)$, and the number of households is estimated at 82,110.

Most of the hurricane damage sustained by dwellings on New Providence was to roofs and ceilings due to strong winds. Water penetration caused subsequent damage to furniture and equipment. The primary damage from flooding results from the impact of rapidly moving waters on houses. This pushes the sides of the building, weakening the structure and at times separating it from the foundation. Additionally, floodwaters can penetrate deep into the earth causing severe damage. Foundation pilings that do not penetrate into load-bearing strata can move, break and shift due to flooding, severely damaging foundations and structures.

With more intense flooding comes more intense damage to foundations. Water traveling at 10 miles per hour $(16 \mathrm{~km} / \mathrm{h})$ exerts the same force as wind blowing at 270 miles per hour $(435 \mathrm{~km} / \mathrm{h})$. Debris and toxic chemicals carried by water can further increase the hazard. Floodwaters also damage electrical circuits, floorboards and piping within and beneath foundations. 
As New Providence began its recovery and clean-up efforts in the hurricane's aftermath, main roads and streets were obstructed with debris and rubble from damaged and destroyed structures and downed trees and power lines (Figure 5).

In New Providence, most vegetative debris consisted of large piles of tree limbs and branches piled by residents on public rights-of-way. This debris is bulky and consumed a significant volume of the roadways.

\section{Berry Islands}

The Berry Islands were lightly impacted in the housing sector. Most damages occurred on roofs, ceilings and equipment. Water penetration damaged building materials to varying degrees. Wind damage was considerable, primarily to shingles and cladding.

Poorly engineered structures, particularly homes, were the most extensively damaged. As on the other islands, the houses most frequently destroyed or severely damaged were older homes. The team observed that some homes had inadequate pier foundations or a complete lack of pier reinforcement, causing severe structural damages.

Figure 5- Fallen trees and accumulations of organic debris
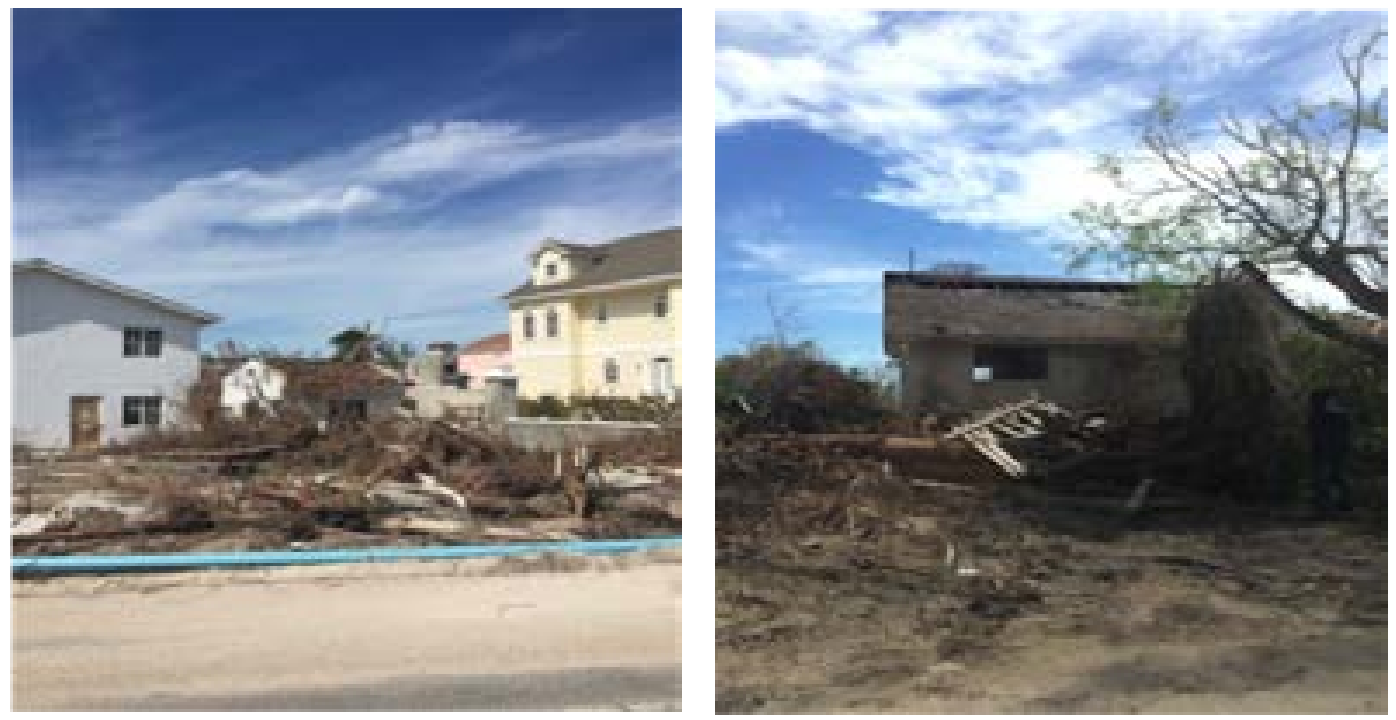

Source: Assessment team 2016

\section{Losses}

Losses in the housing sector relate to the interruption of accommodation services due to severe damage or destruction of the housing stock, making it temporarily or permanently uninhabitable. Estimates focus on interruption of the service regardless of the type of residency (rental or owner occupied). Table 8 shows estimates losses for housing sector after the hurricane. 
Table 8- Losses due to uninhabitable dwellings in the housing sector

\begin{tabular}{|c|c|c|c|}
\hline District & $\begin{array}{l}\text { Estimated rent } \\
\text { per month (\$) }\end{array}$ & $\begin{array}{l}\text { Total } \\
\text { revenue per month }\end{array}$ & Losses \\
\hline New Providence & 925 & 36,075 & 520,907 \\
\hline Grand Bahama & 835 & 622,075 & $8,982,479$ \\
\hline Andros & 750 & 97,500 & $1,407,856$ \\
\hline Berry Islands & 750 & 2,250 & 32,489 \\
\hline Total & & $\$ 687,750$ & $\$ 10,943,731$ \\
\hline
\end{tabular}

Source: Assessment Team, 2016

The estimates assume rental prices of $\$ 750$ to $\$ 925$ per month. This was calculated based on interviews with local inhabitants. Losses were estimated for 9 months in average for all islands.

According to The Central Bank of The Bahamas, Hurricane Matthew caused a large increase in demand for construction workers. Employment should be stable to slightly improved due to construction labour demand. In field interviews, the Ministry of Works and local inhabitants reported that hand labour for roofing reconstruction is paid double the usual rate of $\$ 100$ per day per worker. Another concern is that skill shortages could arise in the construction sector because of the large number of repair activities alongside ongoing construction projects. This may result in a lower quality of repairs than would otherwise be available. As one official said, "Everybody is a roofer now."

\section{Additional costs}

Additional costs include several activities such as cost of demolition of the most affected dwellings (level 4 and some level 3), debris cleaning, staff services and equipment rental. Assuming 12 weeks for rental of trucks, backhoes and other machinery, the additional cost is approximately \$11.2 million (Table 9).

It is estimated that 123,354 cubic yards $(94,311 \mathrm{~m} 3)$ of debris needed to be removed from the affected areas. The cost to fill and transfer each truckload of debris-approximately 20 cubic yards (15 m3)-is estimated at \$165. These additional costs do not include the management of the landfill.

Table 9- Summary of additional costs to the housing sector

\begin{tabular}{|c|c|}
\hline Description & Estimated cost \\
\hline Debris cleaning & $2,374,903$ \\
\hline Cost of demolition & $4,122,153$ \\
\hline Staff Services & $2,283,854$ \\
\hline Rental equipment & $2,425,843$ \\
\hline Total & $11,206,753$ \\
\hline
\end{tabular}

Source: Assessment Team, 2016 


\section{Health}

\section{Introduction}

The health sector suffered moderate effects from Hurricane Matthew. The most severely affected islands were Andros, Berry Islands, Grand Bahama and New Providence. The latter two are the country's most populated islands and host the two largest cities in the country-Freeport and Nassau. These urban centres also concentrate most health care centres and services. Resilience of health infrastructure in these major urban centres seems to be higher compared to that in the family islands.

The total cost of Hurricane Matthew for the country's health sector is estimated at $\$ 3,037,174$. Most damage was caused by wind and flooding or water intrusion. Two clinics were identified as severely damaged. Damage is estimated at $\$ 884,007$.

Losses in the sector related to the interruption of activities before, during and after Hurricane Matthew. After the hurricane, normal operations were not restored in some facilities due to damage or disruption in essential services such as electricity and water supply. Losses are estimated at $\$ 1,754,759$.

Additional costs considered in this report include gas to power generators in health facilities, food provided during emergency operations, residential rental facilities, and paying overtime staff to provide extraordinary hours of service. Additional costs are estimated at $\$ 398,408$.

These estimates are projected from limited data and do not reflect actual payments incurred by the government, with a few exceptions. Estimates are mostly based on assessed damage and relative size of services.

This report includes information related to only the public health care sector. The country capital, Nassau, hosts one private hospital facility, Doctor's Hospital. There are several private clinics across the country, mostly in New Providence and Grand Bahama.

Two sources of information were used to compile data for this chapter:

1. Public Hospital Authority (PHA) assessments of the impact of Hurricane Matthew and operational data.

2. Report: PAHO Health Facility Assessment of the Damage of Hurricane Matthew (October 2016). Pan American Health Organization/ World Health Organisation in collaboration with Bahamas Ministry of Health $(\mathrm{MOH})$ and the PHA. 


\section{Baseline information}

For the purpose of this report, the term clinic identifies any health care facility that provides ambulatory care, and hospital refers to facilities with inpatient services.

The Bahamas public health infrastructure is composed of three inpatient hospital facilities and 83 clinics providing ambulatory health care services across the 17 main inhabited islands. The distribution of clinics by island is shown in Table 10.

Table 11 lists locations of the three public hospitals in The Bahamas. Public hospitals are under direct administration of the Public Hospital Authority, which is part of the Ministry of Health. Most ambulatory clinics are under jurisdictional administration of the Department of Public Health, which is also part of the Ministry of Health. Ambulatory clinics in Grand Bahama are under administration of the Public Hospital Authority.

Table 10- Distribution of public clinics in The Bahamas by island

\begin{tabular}{|l|r|}
\hline \multicolumn{1}{|c|}{ Island } & \multicolumn{1}{r|}{ Clinios } \\
\hline Abaco & 8 \\
\hline Acklins & 5 \\
\hline Andros & 8 \\
\hline Berry Islands & 1 \\
\hline Bimini & 2 \\
\hline Cat Island & 3 \\
\hline Crooked Island & 2 \\
\hline Eleuthera & 14 \\
\hline Exuma & 6 \\
\hline Grand Bahama & 10 \\
\hline Inagua & 1 \\
\hline Long Island & 5 \\
\hline Mayaguana & 1 \\
\hline New Providence & 14 \\
\hline Ragged Island & 1 \\
\hline Rum Cay & 1 \\
\hline San Salvador & 1 \\
\hline & $\mathbf{8 3}$ \\
\hline
\end{tabular}


Table 11- Public hospitals in The Bahamas

\begin{tabular}{|c|c|}
\hline Public Hospitals & Location \\
\hline Princess Margaret Hospital & Nassau \\
\hline Sandilands Rehabilitation Centre & Nassau \\
\hline Rand Memorial Hospital & Freeport \\
\hline
\end{tabular}

\section{Damage}

\section{Public clinics}

Table 12 lists clinics that sustained structural damage from Hurricane Matthew and briefly describes the damage. Two clinics were severely damaged, and they are located in two of the islands most severely affected by Hurricane Matthew.

Coconut Grove Clinic in New Providence had severe roof damage. West End Clinic, a temporary site in Grand Bahama, was reported as destroyed. However, this temporary facility will not need to be repaired; it had been closed for renovation since January 2016. The permanent building suffered no significant damage. West End Clinic additionally has one doctor's residence and two nurses' residences that were damaged. They will have to be repaired with public funds.

One clinic had moderate damage to its roof-Hatchet Bay Clinic on the island of Eleuthera. However, this facility was reported as having unrepaired damage caused by Hurricane Joaquin, and effects of Hurricane Matthew worsened the situation. The damage attributed to Matthew was considered minor. Fourteen other clinics had minor damage.

\section{Public hospitals}

The hurricane damaged all three public hospitals in The Bahamas. Table 13 lists hospitals and other public health facilities damaged by the hurricane and describes the damage.

Two areas of Princess Margaret Hospital-the Children's Ward Block and the Rehabilitation Centre-received moderate damage in roof and windows and water penetration. The Rehabilitation Centre is a rented facility; repair costs are not covered publicly. The Psychiatric building of Sandilands Rehabilitation Centre also sustained moderate damage to the roof and to an automatic security gate. Rand Memorial Hospital in Grand Bahama suffered minor roof damage. Other areas of Princess Margaret Hospital and Sandilands Rehabilitation Centre sustained minor damage. 


\section{Other health facilities}

Davis House is a public health facility that provides diagnostic imaging services. It sustained minor damage to the roof and interior damage due to water intrusion.

\section{Ministry of Health corporate building}

The corporate building of the Ministry of Health suffered significant damage, and was flooded throughout.

Table 14 lists estimated costs of damage to the public health clinics. Table 15 lists the costs for public hospitals and other public health facilities.

Damage to clinic equipment was modest and limited to the clinic in West End, Grand Bahama. That facility also lost all its stock of medications and medical supplies. Damage is estimated at $\$ 30,000$. Residences for doctor and nurses suffered damage to furniture and equipment. One clinic did not have a generator and another had a generator that needed repair. These generator issues could not be attributable to Matthew, but we include them because a generator is an essential asset for a health facility and because of the estimated cost $-\$ 40,700$.

Table 12- Summary of damage to public health clinics by Hurricane Matthew

\begin{tabular}{|l|c|c|l|}
\multicolumn{2}{|c|}{ Name } & Island & Damage \\
\hline Mangrove Cay Clinic & Andros & Minor & Flooding was experienced from rainwater. \\
\hline Mastic Point Clinic & Andros & Minor & $\begin{array}{c}\text { Damage occurred to laundry room roof. Clinic had no } \\
\text { power, no generator and inconsistent water supply. }\end{array}$ \\
\hline Nicholls Town Clinic & Andros & Minor & Minor leaks in roof. No further structural damage. \\
\hline Staniard Creek Clinic & Andros & Minor & Leaks in the roof. Window panes damaged. \\
\hline $\begin{array}{l}\text { Hatchet Bay Clinic } \\
\text { Eleuthera }\end{array}$ & $\begin{array}{c}\text { Moderate1 } \\
\text { (minor at- } \\
\text { tributed to } \\
\text { Matthew) }\end{array}$ & $\begin{array}{l}\text { Roof was previously compromised, but Matthew } \\
\text { increased damage. Clinic experienced leaks and was } \\
\text { operating using a tarp. No further structural damage. }\end{array}$ \\
\hline $\begin{array}{c}\text { Exuma Primary Care } \\
\text { (New George Town } \\
\text { Clinic) }\end{array}$ & Exuma & Minor ${ }^{1}$ & $\begin{array}{l}\text { Minor damage on roof near morgue. Damage to door on } \\
\text { east side. Missing lights on front of building. Water } \\
\text { leaking from multiple sites at windows and doors. } \\
\text { Known issues prior to Matthew: electrical, plumbing } \\
\text { and AC system. }\end{array}$ \\
\hline $\begin{array}{c}\text { Eight Mile Rock } \\
\text { Clinic }\end{array}$ & Grand Bahama & Minor & $\begin{array}{l}\text { Roof leakage, flooding in dental area. No damage to } \\
\text { equipment. }\end{array}$ \\
\hline Freetown Clinic & Grand Bahama & Minor & Minor roof damage. \\
\hline Grand Cay Clinic & Grand Bahama & Minor & Minor leakage in roof. \\
\hline Hawksbill Clinic & Grand Bahama & Minor & Minor roof leaks. Physiotherapy section damaged. \\
\hline High Rock Clinic & Grand Bahama & Minor & $\begin{array}{l}\text { Minor leaks in roof and minor damage to generator } \\
\text { house roof. }\end{array}$ \\
\hline $\begin{array}{l}\text { Pearce Plaza } \\
\text { Specialty Clinic }\end{array}$ & Grand Bahama & Minor & $\begin{array}{l}\text { Minor roof damage. Rented facility, cost not borne by } \\
\text { public sector. }\end{array}$ \\
\hline
\end{tabular}




\begin{tabular}{|l|l|l|l|}
\hline $\begin{array}{l}\text { Sweetingic } \\
\text { sector.ost }\end{array}$ & Grand Bahama & Minor & Minor roof damage and some water intrusion. \\
\hline $\begin{array}{l}\text { West End Clinic } \\
\text { (Temporary) }\end{array}$ & Grand Bahama & Severe & $\begin{array}{l}\text { Building destroyed, 4 ft of water inside with sewer con- } \\
\text { tamination. Furnishings, equipment and files damaged } \\
\text { or destroyed. Temporary facility will not need to be } \\
\text { repaired. The permanent premises, currently under } \\
\text { renovation, suffered no significant damage. Doctores, } \\
\text { currente suffered severe roof and structural dam- } \\
\text { age. Nurse residence \#1 minor roof damage. Nurse } \\
\text { residence \#2 major roof damage. Residences will } \\
\text { need repair. }\end{array}$ \\
\hline Coconut Grove Clinic & New Providence & Severe & $\begin{array}{l}\text { Roof severely damaged. Large part of the membrane } \\
\text { peeled off, resulting in extensive flooding in reception } \\
\text { and child care department. }\end{array}$ \\
\hline Gambier Clinic & New Providence & Minor & Minimal roof damage, no water leaks. \\
\hline South Beach Clinic & New Providence & Minor & Minor roof damage. \\
\hline
\end{tabular}

Source: $\mathrm{PAHO}, \mathrm{MOH}$, and $\mathrm{PHA}$ disaster assessment team.

${ }^{1}$ Damaged prior to Hurricane Matthew.

Table 13- Summary of damage in public health facilities, hospitals and others

\begin{tabular}{|c|c|c|}
\hline Name & Damage & Description \\
\hline Rand Memorial Hospital & Minor & Minor roof damage. \\
\hline $\begin{array}{l}\text { Princess Margaret Hospital- } \\
\text { Main Block }\end{array}$ & Minor & Minor roof damage. \\
\hline $\begin{array}{l}\text { Princess Margaret Hospital- } \\
\text { Children's Ward Block }\end{array}$ & Moderate & Moderate roof damage, window compromised. \\
\hline $\begin{array}{l}\text { Princess Margaret Hospital- } \\
\text { Male Medical } 2 \text { and Female Surgical } 1\end{array}$ & Minor & Roof and water damage. \\
\hline $\begin{array}{l}\text { Princess Margaret Hospital- } \\
\text { Other sections }\end{array}$ & Minor & General repairs needed. \\
\hline $\begin{array}{l}\text { Princess Margaret Hospital- } \\
\text { Rehabilitation centre }\end{array}$ & Moderate & $\begin{array}{l}\text { Extensive roof damage and extensive water intrusion to } \\
\text { the building. Rented facility. }\end{array}$ \\
\hline $\begin{array}{l}\text { Sandilands Rehab. Centre - } \\
\text { Geriatric bldg. }\end{array}$ & Minor & Minor roof and window damage. \\
\hline $\begin{array}{l}\text { Sandilands Rehab. Centre- } \\
\text { Psychiatric bldg. }\end{array}$ & Moderate & $\begin{array}{l}\text { Roof damage. Automatic sliding security gate compro- } \\
\text { mised. }\end{array}$ \\
\hline $\begin{array}{l}\text { Sandilands Rehab. Centre- } \\
\text { Child/Adolescent (CARS) }\end{array}$ & Minor & Damage in roof and doors. \\
\hline $\begin{array}{l}\text { Sandilands Rehab. Centre- } \\
\text { Others }\end{array}$ & Minor & General repairs needed. \\
\hline $\begin{array}{l}\text { Davis House-Imaging Centre } \\
\text { (Grand Bahama) }\end{array}$ & Minor & Roof damage, downed trees, water intrusion. \\
\hline Ministry of Health Corporate Building & Minor & Roof damage, especially the conference room area. \\
\hline
\end{tabular}

Source: $\mathrm{PAHO}, \mathrm{MOH}$, and $\mathrm{PHA}$ disaster assessment team. 
Table 14- Damage in public health facilities attributed to Hurricane Matthew

\begin{tabular}{|l|c|r|}
\hline \multicolumn{1}{c|}{ Name } & Island & Damage \\
\hline Mangrove Cay Clinic & Andros & 2,000 \\
\hline Mastic Point Clinic & Andros & 3,000 \\
\hline Nicholls Town Clinic & Andros & 2,500 \\
\hline Staniard Creek Clinic & Andros & 5,000 \\
\hline Hatchet Bay Clinic ${ }^{1}$ & Eleuthera & 5,000 \\
\hline Exuma Primary Care & Exuma & 3,000 \\
\hline Eight Mile Rock Clinic & Grand Bahama & 31,500 \\
\hline Freetown Clinic & Grand Bahama & 2,500 \\
\hline Grand Cay Clinic & Grand Bahama & 3,000 \\
\hline Hawksbill Clinic & Grand Bahama & 6,500 \\
\hline High Rock Clinic & Grand Bahama & 3,000 \\
\hline Pearce Plaza Specialty Clinic & Grand Bahama & 2,300 \\
\hline Sweetingham Specialt & Grand Bahama & 2,500 \\
\hline West End Clinic & Grand Bahama & 14,453 \\
\hline Coconut Grove Clinic & New Providence & 100,000 \\
\hline Gambier Clinic & New Providence & 3,000 \\
\hline South Beach Clinic & New Providence & 3,000 \\
\hline & Gountry & $\mathbf{5 1 9 2 , 9 5 3}$
\end{tabular}

Source: Estimates from $\mathrm{PHA}$ and $\mathrm{MOH}$ data

${ }^{1}$ Damaged prior to Hurricane Matthew.

Table 15- Damage in public hospital and other health buildings attributed to Hurricane Matthew

\begin{tabular}{|l|r|}
\hline \multicolumn{1}{|c|}{ Name } & Damage \\
\hline Rand Memorial Hospital & 26,500 \\
\hline Princess Margaret Hospital - Main Block & 20,000 \\
\hline Princess Margaret Hospital - Children's Ward Block & 115,000 \\
\hline Princess Margaret Hospital - Male Medical 2 and Female Surgical 1 & 11,000 \\
\hline Princess Margaret Hospital - Other sections & 120,000 \\
\hline Princess Margaret Hospital - Rehabilitation centre & 0 \\
\hline Sandilands Rehabilitation Centre - Geriatric bldg. & 16,000 \\
\hline Sandilands Rehabilitation Centre - Psychiatric bldg. & 165,000 \\
\hline Sandilands Rehabilitation Centre - Child/Adolescent (CARS) & 18,000 \\
\hline Sandilands Rehabilitation Centre - Others & 50,000 \\
\hline Davis House - Imaging Centre & 9,554 \\
\hline Ministry of Health Corporate building & 30,000 \\
\hline \multicolumn{1}{c}{ Total } & $\mathbf{5 2 1 , 0 5 4}$ \\
\hline
\end{tabular}

Source: Estimate from PHA data. 


\section{Losses}

This section outlines losses incurred due to disruption in health services. Estimated losses are summarized in Table 16. The disruption covers three time periods: before, during and after the hurricane.

Pre-hurricane disruption of normal operations included (1) reassignment of resources to prepare health facilities and services and (2) personal preparations undertaken by health staff. This time was estimated as half a day for all public health care sector employees. Estimated pre-hurricane disruption losses are estimated at $\$ 306,177$.

The second period of disruption was the hurricane's passage, estimated as 2.5 days. The three public hospitals are estimated to have operated with only 22 per cent of normal staff during this period. Estimated losses for this period are $\$ 1,293,088$.

The third disruption period was after the departure of the hurricane and included time during which a facility's normal operations remained unrestored because of structural damage or disruption in essential services such as electricity and water supply. Monday 10 October, a National Holiday, also was considered as a non-working day. Estimated losses for the third disruption period are $\$ 155,494$.

Table 16- Losses to disruption in health services, equipment

\begin{tabular}{|l|r|r|r|}
\multicolumn{1}{c}{ Service } & \multicolumn{1}{c}{ Pre-hurricane } & \multicolumn{1}{c|}{ During } & Post-hurricane \\
\hline Clinics & 33,811 & 169,054 & 149,248 \\
\hline Hospitals & 216,181 & 843,106 & \\
\hline Other health services & 56,186 & 280,928 & $6,245.85$ \\
\hline \multicolumn{1}{r|}{ Total } & $\mathbf{\$ 3 0 6 , 1 7 7}$ & $\mathbf{\$ 1 , 2 9 3 , 0 8 8}$ & $\mathbf{\$ 1 5 5 , 4 9 4}$ \\
\hline
\end{tabular}

Source: Estimates from $\mathrm{PHA}$ and $\mathrm{MOH}$ data 


\section{Additional costs}

This section describes additional costs to the public health sector as part of the emergency response and provision of temporary relief. Table 17 shows additional costs considered here include gas for power generators in health facilities, food provided during emergency operations, residential rental facilities, and other costs. Table 18 shows costs of overtime pay to staff.

Estimated additional costs incurred by the public health sector total $\$ 301,603$ in gas, food, rentals and other costs, and $\$ 96,805$ in overtime pay to health care staff.

Table 17- Additional costs associated with emergency response due to Hurricane Matthew

\begin{tabular}{|l|r|r|r|r|r|}
\multicolumn{1}{c}{ Service } & \multicolumn{1}{c}{ Gas } & \multicolumn{1}{c}{ Food } & \multicolumn{1}{c|}{ Residential rental } & \multicolumn{1}{c|}{ Other } & \multicolumn{1}{c|}{ Total } \\
\hline Grand Bahama & 21,132 & 13,994 & 7,700 & 26,344 & 69,170 \\
\hline New Providence & 89,323 & 21,164 & 0 & 111,353 & 221,840 \\
\hline Other family islands & 4,715 & 0 & 0 & 5,878 & 10,593 \\
\hline \multicolumn{1}{|c}{ Total } & $\mathbf{\$ 1 1 5 , 1 7 0}$ & $\mathbf{\$ 3 5 , 1 5 8}$ & $\mathbf{\$ 7 , 7 0 0}$ & $\mathbf{\$ 1 4 3 , 5 7 5}$ & $\mathbf{\$ 3 0 1 , 6 0 3}$ \\
\hline
\end{tabular}

Source: Estimates from $\mathrm{PHA}$ and $\mathrm{MOH}$ data.

Table 18- Additional cost in overtime hours

\begin{tabular}{|l|r|}
\hline \multicolumn{1}{|c|}{ Service } & \multicolumn{1}{c|}{ Overtime } \\
\hline Clinics & 21,132 \\
\hline Rand Memorial Hospital & 58,602 \\
\hline Emergency Operation Centre es and & 17,071 \\
\hline \multicolumn{2}{|c|}{ Total } \\
\hline
\end{tabular}

Source: Estimates from $\mathrm{PHA}$ and $\mathrm{MOH}$ data 


\section{Education}

\section{Introduction}

This section assesses Hurricane Matthews' impact on public education in The Bahamas. Data and analysis covers only publicly funded and operated schools unless otherwise stated.

The education sector suffered moderate damage from the hurricane. There are 34 schools and 13,354 students within the affected region. The single most impacted school was Lowe Sound Primary School in North Andros, which was destroyed by a storm surge on Thursday 6, October. Teachers and students had to be relocated to a new facility that was established on short notice.

Many schools were closed for just over two weeks to allow for cleanup and repairs, this contributed to a total loss of 92,712 student hours. Most additional costs were associated with removal of debris and an increase in subscriptions to school feeding programmes.

The total estimated cost of Matthew to the Education sector on The Bahamas is $\$ 4,758,208$. Most of this is due to damage to school property of $\$ 2.9$ million. Estimated education loss-measured as the value of about 12 school days of lost teaching time for schools in the affected area-is at least $\$ 1.1$ million. Additional costs are $\$ 91,975$, primarily associated with the relocation of the school in Andros. Around 48 per cent of the total estimate of combined damages, losses, and additional costs is for Grand Bahama island, 23 per cent for New Providence and about 15 per cent for Andros and the Berry Islands. The remaining 14 per cent of the total is attributed to the overall loss associated with the closure of all schools in the country before and during Hurricane Matthew.

\section{Baseline information}

Education in the Commonwealth of The Bahamas comes under the jurisdiction of the Ministry of Education, Science and Technology (MoEST). This ministry has responsibility for more than 50,000 primary and secondary level students in approximately 173 educational institutions throughout 14 districts on the major islands (Table 19). There are also about 30 independent schools within the commonwealth with an unknown number of students. Free education is available in publicly funded schools throughout The Bahamas, by law; students must attend school until they are 16 years of age. It is estimated that only 50 per cent of public high school students obtain a high school diploma. ${ }^{16}$ 
Schools in The Bahamas are categorized as follows:

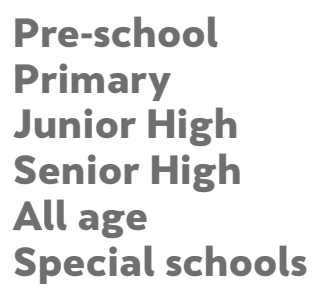

3 to 5 years

5 to $11+$ years

$11+$ to $14+$ years

$14+$ to $16+$ years

5 to $16+$ years

All ages, students with severe

learning disabilities

School calendar is organised from August to June, and students normally attend school from 08:45 to 15:00 hours. Students should receive 180 days of education per year. Although 70 per cent of schools are located on the Family Islands, these account for only 37 per cent of the country's students and 41 per cent of the teachers. ${ }^{17}$

Table 19- Data on public sector education facilities, teachers and students

\begin{tabular}{|c|c|c|c|}
\hline \multicolumn{4}{|c|}{ Public institutions } \\
\hline School type & Establishments & Students & Teachers \\
\hline Primary & 110 & 24,145 & 1,511 \\
\hline Secondary & 41 & 18,696 & 1,834 \\
\hline All-age & 13 & 1,213 & 124 \\
\hline Special schools* & 9 & 204 & 60 \\
\hline Total & 173 & 44,258 & 3,529 \\
\hline
\end{tabular}

* Special schools include schools designated as SURE (Success Ultimately Reassures Everyone), schools for the blind and deaf and 'Exceptional Schools' 


\section{Damage}

Table 20 lists 34 publicly funded schools affected by Hurricane Matthew on Andros Island, Great Harbour Cay, Grand Bahama and New Providence.

Damage to these schools ranged from minimal to severe (Table 21). In New Providence, many schools were unaffected, and damage to others was minor. The only school on the Berry Islands received minor roof damage. On Andros, in contrast, the hurricane destroyed one school and caused varying damage to 10 others. There were twelve schools damaged on Grand Bahama.

The total estimated cost of damage to schools on Andros, the Berry Islands, Grand Bahama and New Providence is $\$ 2,870,255$ (Table 22). The most extensive damage was to Lowe Sound Primary School on Andros, which was destroyed, with damage estimated at $\$ 335,025$.

\section{Andros}

Andros has 10 schools, including two high schools, in the area affected by Hurricane Matthew. The total cost of damages to these schools is estimated at \$522,219. Lowe Sound Primary School was most profoundly affected as it was flooded by several feet of storm surge. The school utilized a rented building as well as two state-owned trailers on its compound. The owner of the rented building was unable to fix it in due time after the storm, so space was found in a building initially built as a hotel. This building is expected to be used for one year whilst a new school is being built.

\section{The Berry Islands}

R.N. Gomez All-Age School on Great Harbour Cay of The Berry Islands hosts 153 students and 15 teachers as well as a security guard and grounds man. The school had minor damage to the roof and no damage to the structure or the equipment. Roof repair is estimated at $\$ 16,000$. 
Table 20- Affected education facilities and enrolment by island

\begin{tabular}{|c|c|c|c|}
\hline Affected island & Facility & Students & Teachers \\
\hline Andros & B.A. Newton Primary & 46 & 5 \\
\hline Andros & Mastic Point Primary & 113 & 7 \\
\hline Andros & Lowe Sound Primary & 150 & 6 \\
\hline Andros & Nicholls Town Primary & 139 & 9 \\
\hline Andros & Bowen Sound Primary & 39 & 3 \\
\hline Andros & Fresh Creek Primary & 105 & 8 \\
\hline Andros & Behring Point Primary & 48 & 4 \\
\hline Andros & Staniard Creek Primary & 36 & 3 \\
\hline Andros & Stafford Creek Primary & 21 & 3 \\
\hline Andros & North Andros High & 369 & 30 \\
\hline Berry Islands & R.N. Gomez All-Age & 153 & 15 \\
\hline Grand Bahama & Bartlett Hill Primary & 267 & 21 \\
\hline Grand Bahama & Freeport Primary & 582 & 35 \\
\hline Grand Bahama & Maurice Moore Primary & 659 & 37 \\
\hline Grand Bahama & Jack Hayward Sr. High & 434 & 53 \\
\hline Grand Bahama & Jack Hayward Jr. High & 467 & 38 \\
\hline Grand Bahama & Lewis Yard Primary & 161 & 15 \\
\hline Grand Bahama & Martin Town Primary & 263 & 21 \\
\hline Grand Bahama & Hugh Campbell Primary & 669 & 38 \\
\hline Grand Bahama & Sis. Mary Patricia Jr. High & 685 & 50 \\
\hline Grand Bahama & Eight Mile Rock High & 550 & 65 \\
\hline Grand Bahama & St. Georges High & 811 & 72 \\
\hline Grand Bahama & The Beacon School & 93 & 23 \\
\hline New Providence & Adelaide Primary & 115 & 10 \\
\hline New Providence & Sybil Strachan Primary & 796 & 45 \\
\hline New Providence & C.W. Sawyer Primary & 681 & 40 \\
\hline New Providence & Garvin Tynes Primary & 970 & 48 \\
\hline New Providence & Gerald Cash Primary & 871 & 49 \\
\hline New Providence & Tiny Tot Preschool & 51 & 4 \\
\hline New Providence & Yellow Elder Primary & 665 & 34 \\
\hline New Providence & A.F. Adderley Jr. High & 741 & 71 \\
\hline New Providence & Anatol Rodgers High & 1030 & 99 \\
\hline New Providence & Government High & 559 & 76 \\
\hline New Providence & Programme SURE & 15 & 10 \\
\hline Total & 34 schools & 13,354 & 1047 \\
\hline
\end{tabular}

Source: Department of Education, The Bahamas (2015) 
Table 21- Affected education facilities by island

\begin{tabular}{|c|c|c|c|c|c|}
\hline \multicolumn{6}{|c|}{ Number of schools by degree of damage } \\
\hline Island & Minimal & Moderate & Heavy & Destroyed & Total \\
\hline Andros & 8 & 1 & 0 & 1 & 10 \\
\hline Berry Islands & 1 & 0 & 0 & 0 & 1 \\
\hline Grand Bahama & 5 & 5 & 2 & 0 & 12 \\
\hline New Providence & 11 & 0 & 0 & 0 & 11 \\
\hline Total & 25 & 6 & 2 & 1 & 34 \\
\hline
\end{tabular}

Source: Estimates by Assessment team, information from field visits and Rapid Needs Assessment (RNA) Team, 2016

Table 22- Estimated damage to education facilities by island

\begin{tabular}{|l|r|r|r|}
\hline \multicolumn{1}{|c}{ Island } & $\begin{array}{c}\text { Total } \\
\text { facilities }\end{array}$ & \multicolumn{2}{c|}{$\begin{array}{c}\text { Damaged } \\
\text { facilities }\end{array}$} \\
\hline Andros (North) & 10 & 10 & 522,219 \\
\hline Berry Islands (Great Harbour Cay) & 1 & 1 & 18,829 \\
\hline Grand Bahama (West) & 13 & 12 & $1,756,229$ \\
\hline New Providence (Southwest) & 11 & 11 & 572,978 \\
\hline Total & $\mathbf{3 5}$ & $\mathbf{3 4}$ & $\mathbf{\$ 2 , 8 7 0 , 2 5 5}$ \\
\hline
\end{tabular}

Source: Estimates by Assessment team, information from field visits and RNA Team, 2016

\section{Grand Bahama}

The total cost of the damage to 12 schools on western side of Grand Bahama is estimated at $\$ 1,756,229$. Ten of them had minimal to moderate damage. Two were heavily damaged: Bartlett Hill Primary School and Lewis Yard Primary School. At these schools, Hurricane Matthew damaged roofs, windows and walls.

The high school at Eight Mile Rock was typical of the moderately damaged schools on Grand Bahama. The assessment team saw that storm winds caused loss of shingles and other moderate damage to the roofs and ceilings of several school buildings. There was also subsequent water damage to equipment in the computer and music rooms. Immediately after the hurricane passed, floodwater covered the school's septic tank, causing it to overflow.

The four other moderately damaged schools on Grand Bahama were Martin Town Primary School, Hugh Campbell Primary School, Jack Hayward Sr. High School and the Sister Mary Patricia Russell Jr. High School. All four received extensive roof damage and some damage to windows and other parts of the buildings. 
Grand Bahama schools with minor damage were Freeport Primary School, Jack Hayward Jr. High School, St. Georges High School, The Beacon School and the Maurice Moore Primary School. These schools suffered minor roof damage from powerful winds and a few instances of water damage.

\section{New Providence}

Schools in affected areas on the island of New Providence were good condition, with minor roof damage.

\section{Losses}

Losses in this sector refer to affected flows such as a reduction in hours or days of classes taught. Schools throughout The Bahamas were closed before and after the hurricane for precautionary reasons. However, in the affected islands these closures were sometimes extended due to hurricane damage to school facilities and time needed to clear debris. Most affected schools remained closed until Tuesday 25 October, causing students to miss about 12 days of classes.

Losses were estimated based on number of hours of education lost, given a school schedule of 8:45 to 15:00 hours. Because public education does not have a market price, losses were estimated using the remuneration factors. ${ }^{18}$ The annual salary for certified teachers with an undergraduate degree ranges from $\$ 25,200$ to $\$ 34,300$ (Ministry of Education, 2009). ${ }^{19}$ Calculations based on this salary range produce an estimated loss of $\$ 659,281$ for the schools in the unaffected areas that were closed for 3 days (Wednesday 5 October to Friday 7 October) as well as a loss of $\$ 1,136,698$ for those in hurricane-affected areas that were closed for a longer period (Table 23). There is therefore an overall loss of $\$ 1,795,979$ to the education sector.

On Grand Bahama, a few schools were unable to reopen by the scheduled date (25 October). This was due to extensive roof damage, damage to equipment and loss of power. Where there was no power for an extended time after 25 October, schools reopened for only a half-day of classes. The schools on Grand Bahama accounted for about 29 per cent of total losses whilst schools on New Providence accounted for a similar 29 per cent.

The estimated losses for the schools on Andros Island are about seven per cent of total losses. This was likely due to the smaller sized institutions across the island. The schools on Andros and the school on the Berry Islands reopened by the scheduled date.

Publicly funded schools across the country lost a total of 92,712 student hours. Many schools planned to adjust their timetables to accommodate for lost time by removing non-essential school activities (e.g., award ceremonies). Schools also adjusted the curriculum to focus only on topics essential for students' major examinations. 
Table 23- Estimated loss to education sector by affected island.

\begin{tabular}{|l|r|r|r|}
\multicolumn{1}{|c}{ Island } & \multicolumn{1}{c}{$\begin{array}{c}\text { Reopened by } \\
\text { 25 Oetober }\end{array}$} \\
\hline Andros Island (North) & 9 & 1 & Lospened after \\
\hline Berry Islands & 1 & 0 & 85,531 \\
\hline Grand Bahama (West) & 9 & 4 & 15,938 \\
\hline New Providence (Southwest) & 11 & 0 & 518,854 \\
\hline Total & $\mathbf{3 0}$ & $\mathbf{5}$ & $\mathbf{\$ 1 , 1 3 6 , 6 9 8}$ \\
\hline
\end{tabular}

Source: Estimations by disaster assessment team, information provided by field visits and the RNA team, 2016

\section{Additional costs}

The total estimate for additional costs is $\$ 91,975$ (Table 24). These costs consider removal of rubble, clean-up activities and other expenses to restore education services promptly. In many cases, teachers and parents assumed the task of cleaning the facilities in their communities. In addition, many teachers volunteered to teach extra hours or where possible on weekends to ensure that students can prepare for upcoming examinations.

Table 24- Total estimated damage, loss and additional costs by affected island

\begin{tabular}{|l|r|r|r|r|r|}
\hline \multicolumn{2}{|c}{ Grand Bahama } & \multicolumn{1}{c}{ New Providence } & \multicolumn{1}{c|}{ Andros } & \multicolumn{1}{c|}{ Berry Islands } \\
\hline Damage & $1,756,229$ & 572,978 & 522,218 & 18,829 & $2,870,254$ \\
\hline Loss $^{*}$ & 518,854 & 516,375 & 85,531 & 15,938 & $1,136,698$ \\
\hline Additional Costs & 12,375 & 6,600 & 72,400 & 600 & 91,975 \\
\hline \multicolumn{1}{|c|}{ Total } & $\mathbf{\$ 2 , 2 8 7 , 4 5 8}$ & $\mathbf{\$ 1 , 0 9 5 , 9 5 3}$ & $\mathbf{\$ 6 8 0 , 1 4 9}$ & $\mathbf{\$ 3 5 , 3 6 7}$ & $\mathbf{\$ 4 , 0 9 8 , 9 2 7}$ \\
\hline
\end{tabular}

"Not included were education losses of $\$ 659,281$ for 3-day school closures in otherwise unaffected areas. Thus, the national loss in the education sector was $\$ 4,758,208$.

At the destroyed Lowe Sound Primary School, additional costs were incurred in renting a new building (Table 25). The rent has increased 40 per cent and will cost an extra \$22,000 over the next year. The school has also increased the number of students served by its school feeding programme. This will cost an extra \$18,000 if sustained for 6 months. Transportation costs have also increased by $\$ 24,000$ per year, because the school's transport must travel farther to take students to the school's temporary location. One of the other major additional costs includes the psychological service teams deployed to provide counselling to teachers and students.

Table 25- Additional costs associated with Lowe Sound Primary

\begin{tabular}{|l|r|}
\multicolumn{2}{|c|}{ Item } \\
\hline Transport (1 year) & 24,000 \\
\hline Rent (1 year) & 22,000 \\
\hline School feeding (6 months) & 18,000 \\
\hline \multicolumn{1}{|c|}{ Total } & $\mathbf{6 4 , 0 0 0}$ \\
\hline
\end{tabular}


INFRASTRUCTURE

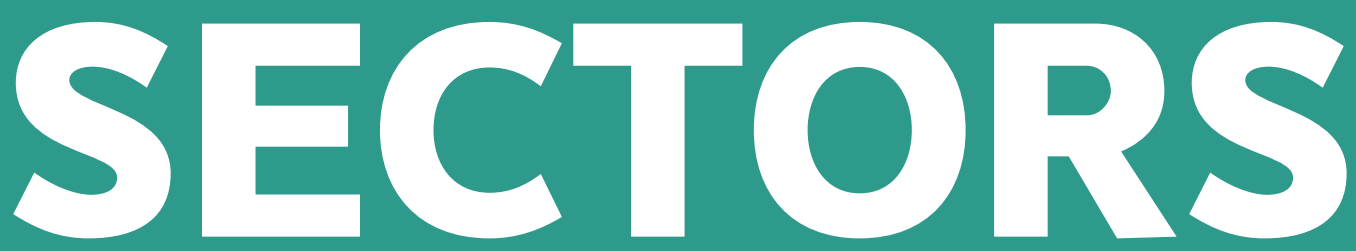




\section{Roads, ports and airports}

\section{Introduction}

This section analyses the effects and consequences of Hurricane Matthew on roads, ports and airports in the Grand Bahama, Andros, New Providence and Berry Islands. These resources are of vital importance for every economic activity of each community and island. They allow that the dynamism of commerce, internal and external, brings great input into the economy of the region through land, sea and air transportation. Roads, ports and airports support specific activities such as fishing, commercial and residential developments and tourism. They also provide primary access to any service required during an emergency.

Damage to this sector was caused primarily by surge flooding. Surges affected roads, airports, bridges, docks and fences in New Providence, Andros, Grand Bahama and the Berry Islands. The estimated damage is $\$ 10,774,733$. Regarding the additional costs, this figure is $\$ 1,899,068$ mainly related to debris removal and fencing.

In general, port structures suffered minor damage to pillars and to loading areas made of concrete slabs. The damages seen result from noncompliance with structural criteria; for this kind of condition, these structures require proper steel reinforcement-which in some cases was absent. They also require adequate concrete mix poured so that any aggregate (stone, gravel, etc.) will be greater than one-third of the slab's camber. The use of fine sand or similar is not recommended because it generates rust on the steel used for reinforcement and, even when used properly, is more expensive because other complements are needed to give the concrete adequate resistance for a particular structure.

Lack of a proper foundation was observed in some of the affected ports, such as the one on the Berry Islands. It sustained major damage in the zones described above, where seashells were used instead of proper aggregate.

At airports, the hurricane caused little or no damage to runways and other main assets. Airport buildings sustained some roof damage, and small sections of fencing were damaged. The Great Harbour Cay airport building had many structural problems before the hurricane. Due to years without improvements or maintenance, the problems worsened when Hurricane Matthew struck.

The information above was provided by the Ministry of Works and Urban Development, Ministry of Environment and Housing, National Emergency Management Agency (NEMA), Berry Islands Administration Office, Grand Bahama Port Authority, Grand Bahama Minister, Chamber of Commerce 
and the Ministry of Social Services, and others. We obtained the information through interviews with each institution and verified it during field inspections of the areas most affected by the hurricane.

\section{Baseline information}

\section{Road network}

Field inspections of roads revealed many deficiencies due to construction practices unsuitable for the zones in which they are located. As illustrated in Figure 6, vulnerability prior to the disaster was considered high in the country for the following reasons:

A. Lack of technical supervision during construction to ensure a correct outcome

B. Inefficient and low quality of structural components and construction deficiencies.

C. Use of inappropriate materials given the local hazards, so the structure deteriorates readily.

D. Absence of updated modelling information applied to current design and construction such as sea walls.

E. Absence of proper draining channels to conduct rainfall adequately.

F. Absence of proper draining channels to conduct rainfall adequately

Figure 6- Pavement structure and draining problems, South Beach San Andreas
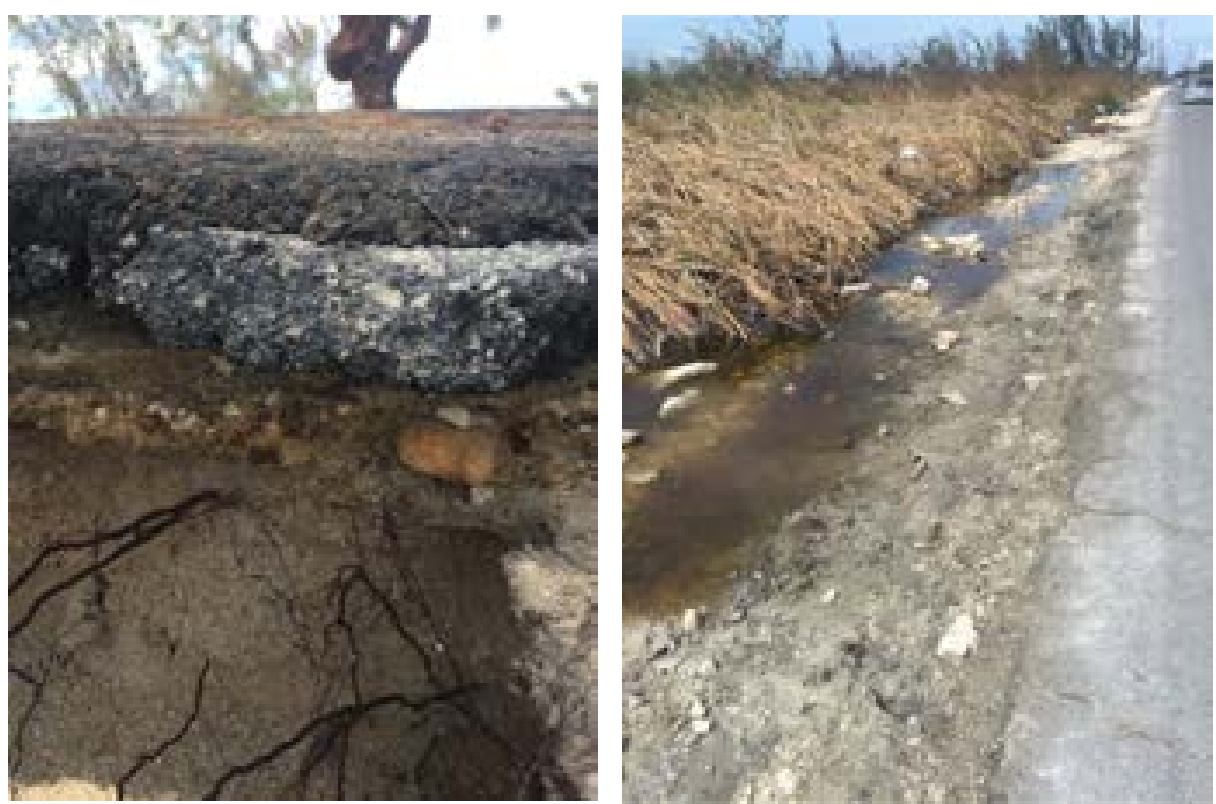

Source: Assessment Team, 2016 


\section{Airports}

Two of the three main airports in The Bahamas are included on this assessment report: Lynden Pindling International Airport on New Providence and Grand Bahama International Airport. Also included are the Great Harbour Cay Airport on Berry Islands and Andros Town International Airport (Table 26).

All four of these airports have paved runways, but none suffered any damage as a direct consequence of Hurricane Matthew. Mostly, the terminal and administration offices suffered minor damage to the roof cover and ceilings throughout the whole structure (Figure 7). The roofs are shingled; the ceilings have suspended light supports in internal offices and an alternate ceiling system for the outdoors.

Figure 7- Affected airports in Berry Islands and New Providence.
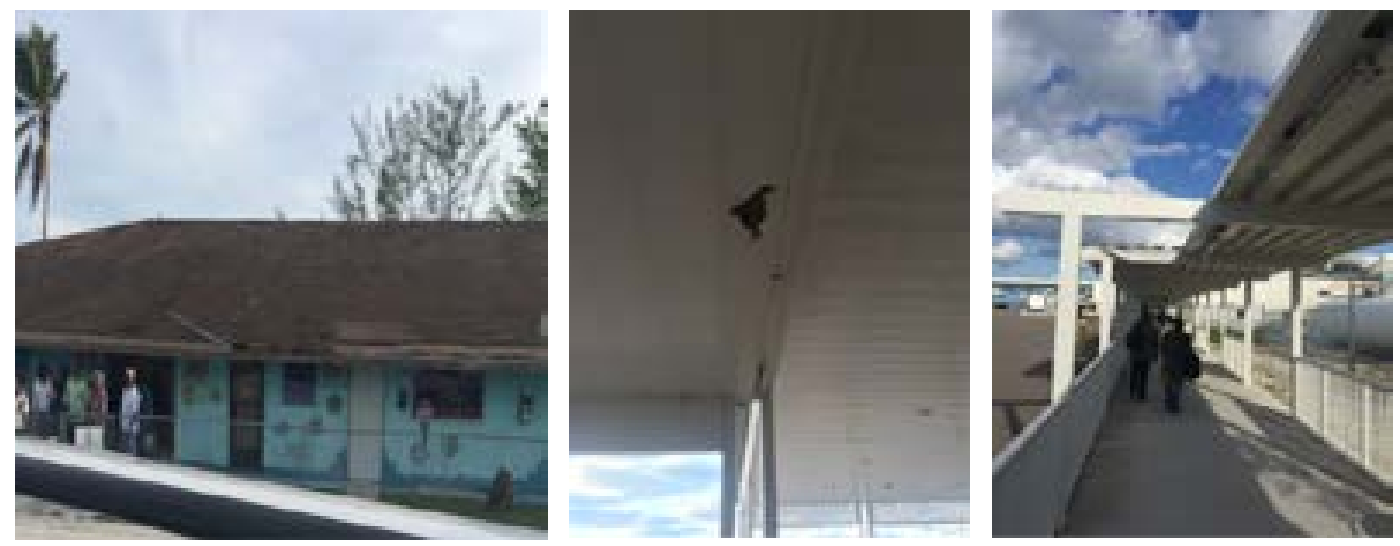

Source: Assessment Team, 2016

Table 26- Airport runways on affected islands

\begin{tabular}{|c|c|c|c|c|}
\hline \multirow[t]{2}{*}{ Airport } & \multicolumn{2}{|c|}{ Runway length } & \multirow[t]{2}{*}{ Condition } & \multirow[t]{2}{*}{ Finish } \\
\hline & $(\mathrm{ft})$ & (m) & & \\
\hline Andros & 4,058 & 1,237 & Good & Paved \\
\hline Berry Islands & 4,501 & 1,372 & Good & Paved \\
\hline New Providence & 19,872 & 6,057 & Good & Paved \\
\hline Grand Bahama & 11,020 & 3,359 & Good & Paved \\
\hline
\end{tabular}

Source: Assessment Team, 2016 


\section{Ports}

The Bahamas has 42 official ports of entry. The islands assessed in this report possess 24 official ports listed for the various economic activities to use. This equals 57 per cent of the country's ports. This confirms that sea-related activities are of great importance to the country, and tourism represents over 60 per cent of the Bahamian gross domestic product. According to the Observatory of Economic Complexity, The Bahamas exported $\$ 3.77$ billion and imported $\$ 9$ billion through its main ports.

Port structures that suffered the most hurricane damage were generally small and used mostly by local fishery activity, which is of great importance to the economic sector. These ports, docks and harbour structures present a simple construction process and design, as seen in Figure 8.

Figure 8- Affected docks in West End and Berry Islands
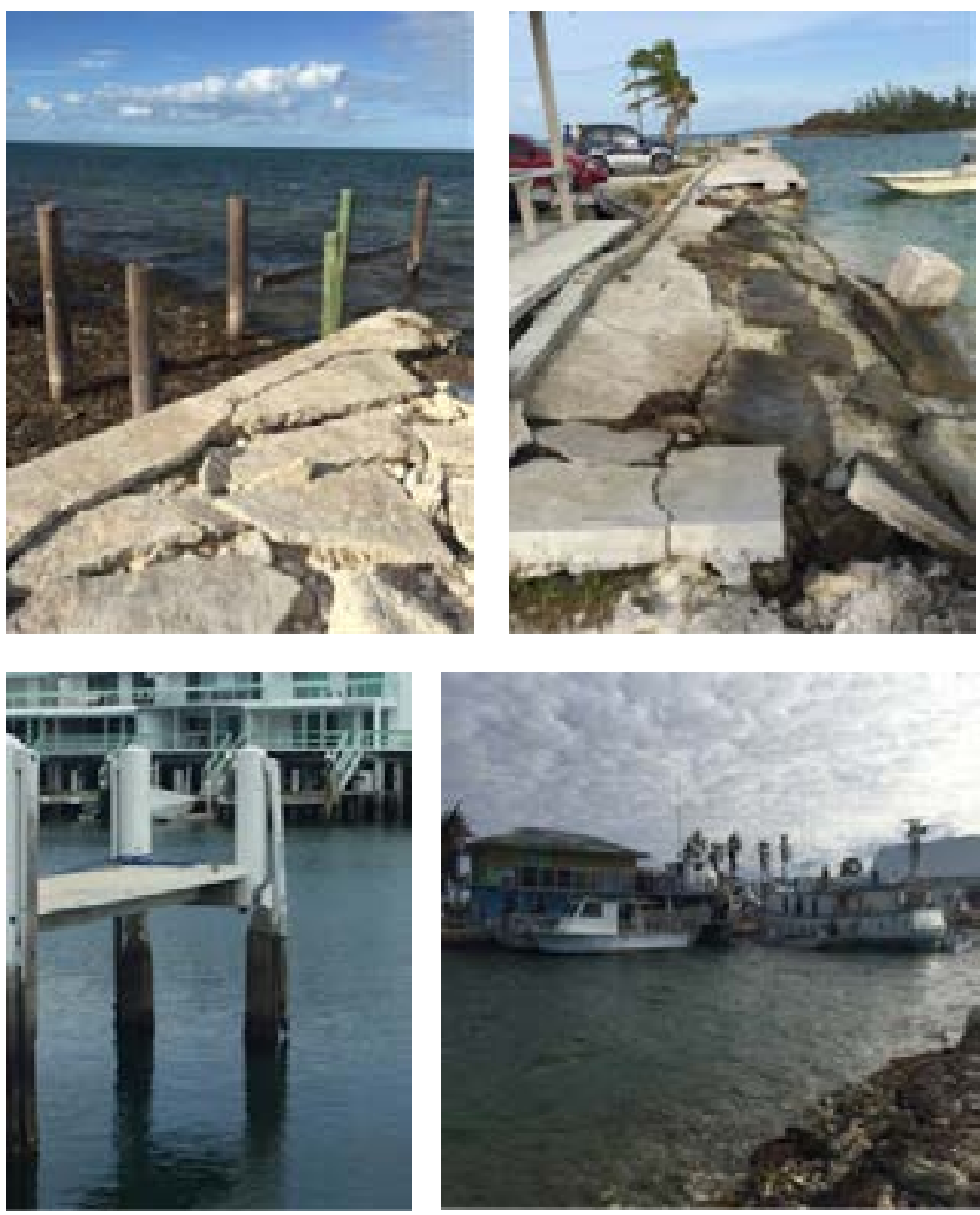

Source: Assessment Team, 2016 
Docks in areas affected by the hurricane have the following design and construction specifications:

A. Foundations in docking areas are composed of concrete and wooden pillars of approximately 10-12 inches $(25$ to $30 \mathrm{~cm}$ ) in diameter.

B. Loading/unloading areas are made of a concrete slab supported by pillars in some cases. In others, the slab is set on the ground atop deficient materials such as seashells, beach sand and other components that provide little no structural support, as seen in Figure 8.

C. Lack of proper lateral bracing where a dock is subject to lateral forces such as storm winds and tides.

\section{Damage}

Table 27 summarizes hurricane damage to the transportation sector. Most damage to roads, ports and airports was reported on New Providence, Berry Islands, Grand Bahama and Andros. The entire affected infrastructure and its restoration are under the responsibility of The Ministry of Works and Urban Development and The National Emergency Management Agency. Both entities were also in charge of coordination and deployment of rapid response teams, so that all necessary and major infrastructures would be rehabilitated as soon as possible.

Roads were affected mainly by excess water flow on surfaces because of storm surges, mostly on coastal highways. This water flow deposited a great amount of debris on the road and caused minor fractures on the skin coat of bituminous materials. A small number of potholes formed as well. In addition, one vehicle bridge was moderately damaged. No bridge collapse was observed.

The hurricane caused no major damage to airports. They mainly suffered roof and ceiling damage and some additional costs (fences, etc.).

Seaports suffered minor damage to pillars on small dock structures, and fractures on concrete slabs in some sectors.

Table 27- Damage summary for transportation sector

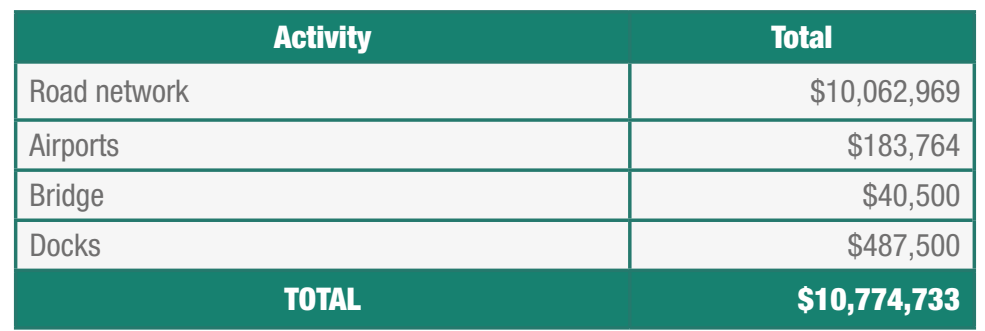

Source: Assessment Team, 2016 


\section{Road network: distribution, access and coastal roads}

Approximately 1,689 miles $(2,718 \mathrm{~km})$ of road in The Bahamas is classified as highway, of which 969 miles $(1,560 \mathrm{~km})$ are finished with asphalt or paved. The country also has 720 miles $(1,158 \mathrm{~km})$ of unpaved or unfinished roads. The hurricane affected mainly coastal highways and roads on Grand Bahama, Andros, New Providence and Berry Islands. The properly paved coastal routes on these four islands have lengths, respectively, of approximately 71, 73, 73 and 7 miles (114, 117, 118 and $11 \mathrm{~km})$.

Hurricane Matthew affected about 60 miles $(96 \mathrm{~km})$ of roads, with damage estimated at $\$ 7,340,132$ (Table 28 ).

Table 28- Damage to road network

\begin{tabular}{|l|r|}
\hline \multicolumn{1}{|c|}{ Island } & \multicolumn{1}{c|}{ Total } \\
\hline New Providence & $2,000,000$ \\
\hline Berry Islands & 160,580 \\
\hline Grand Bahama & $2,562,112$ \\
\hline Andros & $2,617,440$ \\
\hline \multicolumn{1}{c}{ TOTAL } & $\mathbf{7 , 3 4 0 , 1 3 2}$ \\
\hline
\end{tabular}

Source: National Emergency Management Agency, Assessment team, 2016

The road network is mainly paved, so most hurricane damage consisted of potholes formed by erosion due to heavy water flow. The absence of proper drain channels, sidewalk gutters, ditches, gutters and counterdrains generates excess water flow to damage the pavement structure at laterals. This allows water to run without restraint, causing it to reach and residences.

It is important to evaluate the potential for building storm water retention ponds in particular strategic areas. Such ponds can regulate the delivery of rainfall to rivers, minimizing the risk of a possible flood because of excess water. Ideally, a storm water retention pond is designed so that the land vents at least 10 per cent less water flow than if in a normal undeveloped condition. This allows the region to start minimizing the impact of rain into the river network throughout the country.

Roads along the coastline protected by a sea wall suffered minor damage. Some sea walls were significantly damaged (Table 29). In several sea wall sectors, the top horizontal slab separated from the vertical wall. This was caused by lack of proper steel reinforcement, low quality aggregates, low quality concrete mix, lack of proper professional inspection and a design that did not account for likely weather hazards. 
Table 29- Damage to sea walls

\begin{tabular}{|c|c|}
\hline Island & Total \\
\hline New Providence & 121,500 \\
\hline Berry Islands & 0 \\
\hline Grand Bahama & $1,286,775$ \\
\hline Andros & $1,314,562$ \\
\hline
\end{tabular}

Source: National Emergency Management Agency, Assessment team, 2016

\section{Bridges}

During the field inspections, only one bridge was observed to sustain significant damage, estimated at $\$ 40,500$ (Table 30$)$. This bridge crosses a stream in the area of Conch Sound in Nicholls Town, north-eastern Andros Island. The asphalt surface of the bridge was damaged by lateral forces from rising water level as a result of storm surge and streamflow. As shown in Figure 9, this bridge does not have any lateral concrete reinforced walls, so that any water flow would be channelled below the bridge, as proper design requires. These lateral walls would also bring additional stability to the whole structure, so that it can withstand an extraordinary event such as a hurricane.

It is of vital importance that, for the design of these types of structures, a proper flood routing study is performed. This should include detailed topography about 220 yards ( $200 \mathrm{~m}$ ) both upstream and downstream from the river to determine the specific expected passage of floodwater flow above the riverbed. Also, it is recommended that all wooden structural components be replaced by concrete or steel. This will avoid further damage caused by deterioration of the existing material or even avoid complete collapse in a similar storm event.

Figure 9- Affected bridge, Conch Sound vicinity
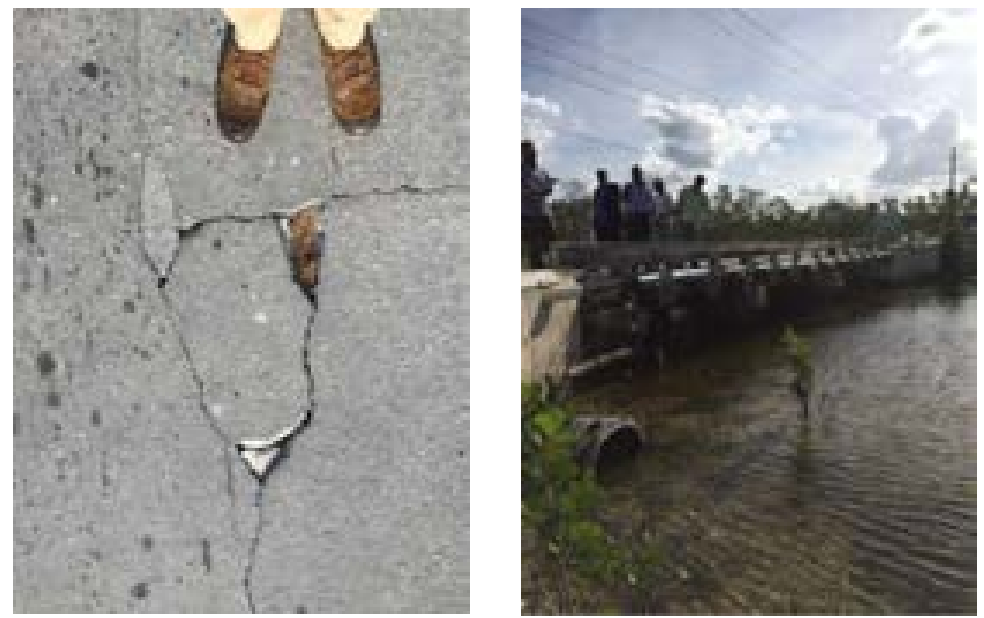
Table 30- Damage to bridges

\begin{tabular}{|c|c|c|}
\hline \multicolumn{2}{|c|}{ Bridge } & \multicolumn{1}{c|}{ Type of damage } \\
\hline Low level bridge & $\begin{array}{c}\text { Fractures on asphalt surface and minor wooden foundation } \\
\text { damage due to extreme lateral forces and excess water flow }\end{array}$ & $\$ 40,500$ \\
\hline TOTAL & $\mathbf{\$ 4 0 , 5 0 0}$ \\
\hline
\end{tabular}

Source: Assessment team, 2016

\section{Docks}

According to field visits, docks affected by the hurricane suffered minor to moderate damage. Mainly the docks were damaged due to vertical water pressure generated by storm surges, lateral additional flows to which each structure was subjected, and, in some cases, low-quality design and construction practices. Cost of repairing or replacing docks was estimated as follows:

A. Restoration of pillars and concrete slab: $\$ 125 / \mathrm{yd} 2(\$ 150 / \mathrm{m} 2)$.

B. Sea wall along the docking area: $\$ 375 / y d 2(\$ 450 / \mathrm{m} 2)$.

Additionally, small sectors of sea walls adjacent to docks were damaged. For this report, total damage to docks in the transportation sector is estimated at $\$ 487,000$ (Table 31).

Table 31- Damage to docks.

\begin{tabular}{|l|r|}
\hline \multicolumn{1}{|c|}{ Island } & \multicolumn{1}{c|}{ Total } \\
\hline New Providence & 19,100 \\
\hline Berry Islands & 43,400 \\
\hline Grand Bahama & 87,000 \\
\hline Andros & 337,500 \\
\hline \multicolumn{1}{c}{ TOTAL } & $\mathbf{\$ 4 8 7 , 0 0 0}$ \\
\hline
\end{tabular}

Source: National Emergency Management

Agency, Assessment team, 2016 


\section{Losses}

Losses in this sector are related to interruption of tourism. Airports and ports had to be closed for several days. The closures affected the island's economy, and the relevant revenue losses are estimated in the Tourism chapter.

No revenue was lost as a result of road closures, because no toll-related losses occurred on the visited islands. No motor vehicle infrastructure was affected. As mentioned in other sections of this report, most road damage was minor to moderate and did not present any revenue loss, according to field inspections and information from local government institutions. No bridges were reported collapsed or damaged enough to be catalogued as out of service, so no roads were closed for this reason.

\section{Additional costs}

The additional costs considered in this analysis relate mainly to debris removal and the restoration of simple fencing built with galvanized wire (Table 32). Grand Bahama and New Providence had the highest additional costs.

It is important to have an improved construction process for fence installation. In general, it is better to weld every joint in the fence and pour a small amount of concrete for pole installation. This concrete will serve as a small foundation for this fence system and increase the rigidity of the structure.

Table 32- Summary of additional costs (\$) in the infrastructure sector

\begin{tabular}{|c|c|c|c|c|c|}
\hline Activity & $\begin{array}{c}\text { New } \\
\text { Providence }\end{array}$ & $\begin{array}{c}\text { Berry ls- } \\
\text { lands }\end{array}$ & $\begin{array}{l}\text { Grand } \\
\text { Bahama }\end{array}$ & Andros & Total \\
\hline Debris removal & 516,000 & 17,205 & 377,454 & 289,204 & $1,199,863$ \\
\hline Fencing & 165,000 & 24,356 & 307,075 & 202,775 & 699,206 \\
\hline TOTAL & $\$ 681,000$ & $\$ 41,561$ & $\$ 684,529$ & $\$ 491,979$ & $\$ 1,899,069$ \\
\hline
\end{tabular}

Source: Assessment team, 2016 


\section{Telecommunications}

\section{Introduction}

Though wireless telecommunications services were resilient considering the magnitude of the hurricane, it caused extensive outages to wired services including landline telephone, fixed internet and cable television. The longest outages were in Grand Bahama, followed by New Providence. Andros was affected through partial collapse of an important telecommunications tower, and several cellular installations lost service in the Berry Islands. Damages to telecommunications infrastructure was also reported in Inauga, Acklins, Exuma, Long Island and Bimini.

The most widespread type of damage occurred because of collapsed utility poles and downed telecommunications lines. Fallen trees and limbs were major contributors to this damage. The network was also affected by damage to the power infrastructure. These effects included loss of commercial power at telecommunications facilities, as well as delays to repairs of network infrastructure until power companies could address damages to utility poles and restore power distribution lines. There was also wind damage to buildings owned by telecommunications companies, but this did not extensively affect network switches or other high-value equipment, in contrast to what happened during Hurricane Joaquin.

In general, telecommunications infrastructure provided better support to disaster preparation and response operations during Hurricane Matthew than during Hurricane Joaquin. Wireless coverage had broader availability during and after this storm, which helped facilitate response efforts of individuals and of the private and public sectors. Because cellular services were more functional, there was less reliance on satellite telephones, which are available in limited numbers and can have challenges in their deployment. Unlike the occasion of Hurricane Joaquin, the National Emergency Management Agency was able to send SMSbased public warning and information messages to Bahamas Telecommunications Company (BTC) cell phones in affected areas before and after Hurricane Matthew.

Damages in the telecommunications sector are estimated at $\$ 9.86$ million, losses at $\$ 13.60$ million, and additional costs at $\$ 10.26$ million. Total estimated cost of the storm to the telecommunications sector is $\$ 33.72$ million. This is about 50 per cent more than the total cost associated with Hurricane Joaquin in this sector. Though there was less damage to cellular base stations and high-value electronics equipment from this storm than from Hurricane Joaquin, the overall cost was driven higher by prolonged outages to cable television, fixed-wire telephone lines, and broadband internet services in highly populated areas. 
Information from this report was collected from interviews with BTC personnel and public information released by BTC, Cable Bahamas and NewCo 2015 Limited (NewCo) ${ }^{20}$. This estimate is also informed by data collected as part of the damage and loss assessment performed after Hurricane Joaquin.

\section{Baseline information}

The two primary providers of telecommunications services are BTC and Cable Bahamas Ltd. Both provide internet, cable television and landline telephone services. BTC also provides cellular service to the islands, although a Cable Bahamas-affiliated company, NewCo, is entering the market, having built out a nationwide cellular network that launched on 1 October. NewCo has about 73 new cellular sites in Nassau and Grand Bahamas. However, because the service is just launching, few NewCo subscribers were affected by storm-related outages.

Both BTC and NewCo are majority owned by entities controlled by the government of The Bahamas, though there are plans for the government to divest its ownership to a private entity in the near future. The estimated damage, losses and additional costs are allocated to the public sector in proportion to the extent of government ownership of the affected entities.

Data from the International Telecommunications Union for the year 2015 indicates that for every 100 people in The Bahamas, there were about 21 fixed broadband subscriptions, 80 mobile cellular subscriptions, and 31 fixed telephone subscriptions.

BTC reported that their networks had undergone significant hardening as a result of lessons learned from Hurricane Joaquin and credited this hardening for the relatively resilient performance of telecommunications during Hurricane Matthew. After Joaquin, telecommunications services in Acklins had been cut off for months, but no island experienced a prolonged outage from Matthew.

\section{Damage}

Telecommunications services were particularly hard hit in Grand Bahama. Fixed-wire networks were impacted by damages to utility pole infrastructure, and trees falling on wires. In some cases, as NewCo reported, this affected fibre optic backhaul systems servicing cellular towers, knocking them out of service. While no cellular towers in Grand Bahama collapsed during the storm, many antennas and other equipment were blown away. BTC service was lost in West End, East End, McLeans Town, Sweetings Cay, Eight Mile Rock, and Deep Water Cay. A number of sites were affected by the loss of commercial power and had to be refuelled regularly. NewCo reported that some access roads to cell tower sites were blocked by debris, delaying repairs. 
The restoration process took longer in Grand Bahama than in other islands, due to the extent of damage. As in Joaquin, the process of restoring communications lines was delayed until the power utility could make repairs and replacements to utility poles. Ten days after the storm, on 16 October, Cable Bahamas reported that only 8 per cent of wired network services on the island were restored. Restoration of service reached 53 per cent by 26 October and 74 per cent by 31 October. Completion was estimated by 21 November.

Cellular service continued in many parts of New Providence during Hurricane Matthew. There were outages in some areas because of damage to towers or lack of commercial power. Generators were deployed to provide power on a temporary basis. Two BTC towers lost service in the eastern part of the island, but they came back online about two weeks after the storm. Wired networks on the island were broadly affected by fallen poles and cables. In New Providence, restoration work was completed by about three weeks after the storm.

In North Andros, service to all cellular, fixed telephone and internet connections was lost after the storm, due to partial collapse of a 260-foot $(80 \mathrm{~m})$ communications tower in Nicholls Town that served as a primary relay between North Andros and New Providence. The top 110 feet (34 $\mathrm{m})$ of the tower broke off and fell to the ground, destroying various antennas and microwave dishes mounted there. However, a fibre optic cable link did remain between Central Andros and New Providence, and so North Andros's telecommunications connection to the outside world was restored once faults were repaired in the fibre connection between North Andros to Central Andros. Cellular service to North Andros was fixed on a temporary basis by mounting antennas at the top of the broken-off telecommunications tower. It was also reported that there was roof damage to the BTC building in Fresh Creek, Central Andros. Cable Bahamas reported that restoration work was 96 per cent completed by November 9, but that some work remained to be done in the most damaged area of Lowe Sound.

BTC reported significant damage to three cell sites in the Berry Islands. Service to Bullocks Harbour was restored on 13 October, seven days after the storm. Sites at Chub Cay and Stirrup Cay, requiring additional parts that needed to be imported, were not repaired until several days later. Landline and internet connectivity were still unavailable in the islands as of the disaster assessment team's visit on 26 October.

The islands of Inauga, Acklins, Exuma, Long Island and Bimini also had damage to telecommunications systems. BTC reported that services to Acklins were restored in 6 hours, but that some parts of The Exumas were still without cellular service as of 31 October. Cable Bahamas reported damage to satellite installations in Inagua, Exuma, Long Island and Bimini. Table 33 shows the dollar value of damage by island and type pf communication service. 
Table 33- Damage by island and type of telecommunications service

\begin{tabular}{|l|r|r|r|}
\multicolumn{1}{|c}{ Affected island } & \multicolumn{2}{c|}{ Wired } & \multicolumn{1}{c|}{ Total } \\
\hline Andros & 580,000 & 250,000 & 830,000 \\
\hline Berry Islands & 420,000 & 90,000 & 510,000 \\
\hline Grand Bahama & $1,120,000$ & $3,500,000$ & $4,620,000$ \\
\hline New Providence & $1,080,000$ & $1,800,000$ & $2,880,000$ \\
\hline Other islands & 540,000 & 475,000 & $1,015,000$ \\
\hline \multicolumn{1}{|c|}{ Total } & $\mathbf{\$ 3 , 7 4 0 , 0 0 0}$ & $\mathbf{\$ 6 , 1 1 5 , 0 0 0}$ & $\mathbf{\$ 9 , 8 5 5 , 0 0 0}$ \\
\hline
\end{tabular}

Source: Assessment team, 2016

\section{Losses}

The assessment team calculated losses, shown in Table 34, based on estimated number of customers affected on each island for each type of telecommunications service, estimated average length of time of service outage, and estimated average revenue per user (ARPU) for each type of service.

Losses related to cellular services account for only about 5 per cent of total losses in the telecommunications sector. This is because outages were relatively brief and mostly occurred in less populated areas. In contrast, wired services sometimes took far longer to be restored. Areas of the most populated islands of New Providence and Grand Bahama were affected by extended outages.

Table 34- Losses in the telecommunications sector

\begin{tabular}{|l|r|r|r|r|r|}
\hline \multicolumn{2}{c}{ Gellular } & \multicolumn{1}{c}{ Telephone } & \multicolumn{1}{c|}{ Broadband } & \multicolumn{1}{c|}{ Cable } \\
\hline Andros & 47,251 & 21,073 & 69,200 & 79,182 & 216,706 \\
\hline Berry Islands & 10,500 & 8,362 & 27,460 & 31,421 & 77,744 \\
\hline Grand Bahama & 357,846 & 455,985 & $1,497,350$ & $1,713,342$ & $4,024,524$ \\
\hline New Providence & 218,289 & $1,112,618$ & $3,653,580$ & $4,180,608$ & $9,165,095$ \\
\hline Other islands & 36,793 & 9,377 & 30,791 & 35,233 & 112,194 \\
\hline \multicolumn{1}{|c|}{ Total } & $\mathbf{\$ 6 7 0 , 6 8 0}$ & $\mathbf{\$ 1 , 6 0 7 , 4 1 5}$ & $\mathbf{\$ 5 , 2 7 8 , 3 8 2}$ & $\mathbf{\$ 6 , 0 3 9 , 7 8 6}$ & $\mathbf{\$ 1 3 , 5 9 6 , 2 6 2}$ \\
\hline
\end{tabular}

Source: Assessment team 


\section{Additional costs}

Table 35 shows the additional costs to the telecommunications sector. These costs are dominated by labour, support and travel expenses associated with work needed to restore telecommunications services. A small portion of the additional costs is diesel fuel for generators and backup systems providing emergency power to cell towers.

A further expense is the free $\$ 5$ credit given to all customers by BTC shortly after the hurricane. This free credit enabled people to have access to cellular services to communicate at a crucial time when many retail locations would not have been able to provide top-up services to prepaid customers.

Table 35- Additional costs in the telecommunications sector

\begin{tabular}{|c|c|}
\hline Expense & Gost \\
\hline Labour, support and travel & $8,691,680$ \\
\hline Extra fuel for generators & 73,500 \\
\hline$\$ 5$ top-up credit to customers & $1,499,391$ \\
\hline Total additional costs & $\$ 10,264,571$ \\
\hline
\end{tabular}

Source: Assessment team 


\section{Power}

\section{Introduction}

Most of the damage in the power sector was to transmission, distribution and service lines as a result of high winds that felled utility poles and caused trees to collapse onto power lines. The storm centre passed very near Clifton Pier Power Station complex at the western end of New Providence, and it was damaged by high winds and storm surge. The generation station at Fresh Creek, Andros was damaged when the building housing its generators blew away.

Restoration of power took several weeks, with longer delays in remote settlements far from population centres. Grand Bahama was most affected by long-term power outages, with the last area to be energized-in West End-coming back on line five weeks after the storm. In New Providence, power was restored within three weeks, though isolated outages continued due to service line damages for individual customers.

In the power sector, damages are estimated at $\$ 16.35$ million, losses are estimated at $\$ 7.85$ million, and additional costs are $\$ 23.62$ million. The total cost of Hurricane Matthew to the power sector is estimated to be $\$ 47.81$ million.

Information on the power sector was collected from interviews with executives of Bahamas Power and Light (BPL) and from public information provided by the Grand Bahama Power Company (GBPC).

\section{Baseline information}

Power in New Providence and the Family Islands is provided through Bahamas Power and Light (BPL), a privately managed subsidiary of the publicly owned Bahamas Electricity Company (BEC). Power in Grand Bahama is distributed by Grand Bahama Power Company. At the time of the storm, BPL was servicing over 107,000 customers, and there were approximately 20,000 power customers on Grand Bahama.

Each island has its own generation system. Most islands' generators run on diesel power, though heavy fuel oil is also used in New Providence. Use of renewable energy sources is limited, and those systems that exist tend to be independent of the larger grid. Provisions in recent laws are providing a legislative framework to support the expansion of green energy, but such projects are not yet underway.

BPL has only been in existence since the end of 2015, and it was created partly because of a need for broad restructuring of debt owed by $B E C$. The debt has been restructured, but BPL remains under financial 
strain. Its ongoing losses hinder BPL's ability to finance needed capital upgrades to its aging generation and distribution systems. BPL will be further strained by losses related to Hurricane Matthew, as its distribution network is not insured and other damages are not likely to meet its insurance deductible.

\section{Damage}

Table 36 summarizes the damage in the power sector. The greatest damages were experienced on Grand Bahama, which lost almost 2,000 transmission and distribution poles. In some cases, long rows of poles collapsed in a chain reaction; as one pole fell, the power and telecommunications lines attached to it pulled down the next pole. The poles were generally of a higher grade on Grand Bahama than in areas of Long Island and Crooked Island where large numbers of poles fell during Hurricane Joaquin, Grand Bahama poles also tended to be somewhat older, which may have contributed to their collapse. Some poles showed signs of damage due to aging and prolonged exposure to ultraviolet rays from the sun. A number of the oldest wooden distribution poles in West End appeared to have been in the process of being replaced around the time of the hurricane. Nonetheless, a high number of these poles fell, taking down power lines and in some cases damaging nearby buildings. On the other hand, newer transmission poles made out of a composite material do not appear to have sustained much damage.

Table 36- Summary of damage in the power sector

\begin{tabular}{|l|r|r|r|}
\hline \multicolumn{2}{|c|}{ Description } & \multicolumn{1}{c|}{ Public } & \multicolumn{1}{c|}{ Total } \\
\hline Damage to generation systems & $5,768,500$ & $1,000,000$ & $6,768,500$ \\
\hline Andros & $2,700,000$ & & $2,700,000$ \\
\hline New Providence & $3,068,500$ & $1,000,000$ & $4,068,500$ \\
\hline $\begin{array}{l}\text { Damage to transmission and distribu- } \\
\text { tion networks }\end{array}$ & $1,475,000$ & $8,100,000$ & $9,575,000$ \\
\hline Andros & 525,000 & & 525,000 \\
\hline Grand Bahama & & $8,100,000$ & $8,100,000$ \\
\hline New Providence & 900,000 & & 900,000 \\
\hline Other islands & 50,000 & & 50,000 \\
\hline & $\mathbf{7 , 2 4 3 , 5 0 0}$ & $\mathbf{9 , 1 0 0 , 0 0 0}$ & $\mathbf{1 6 , 3 4 3 , 5 0 0}$ \\
\hline
\end{tabular}

Source: Assessment team, 2016

In New Providence, BPL lost 207 poles and 87 transformers, and made 1,422 splices as part of repairs. BPL also replaced 31,275 feet $(9,533 \mathrm{~m})$ of conductor on the island, along with 64,680 feet $(19,714 \mathrm{~m})$ of service wire, 143 insulators and 291 lightning arrestors.

There was significant damage at the site of the Clifton Pier Power Station in western New Providence. A pier used for offloading oil from ships 
was destroyed. There was damage to the roof of the generation building and cladding of smoke stacks. An administration building was submerged by storm surge. Water intake pipes were clogged with seaweed. The pier had been in a degraded state before the storm. It is valued here at \$1 million, though its replacement will cost substantially more. Other repairs at Clifton Pier are budgeted at $\$ 3.07$ million.

In the Family Islands, primarily Andros, 77 poles were broken and 34 poles were leaning. Vegetation had to be cleared from 130 spans. On Andros, the 21 - by 27 -foot ( 6.4 - by $8.2-\mathrm{m}$ ) metal building housing generators at the generation facility near Fresh Creek was destroyed. It was similar to the building damaged by Hurricane Joaquin in San Salvador, and its generators were damaged by exposure to the elements. The building will cost $\$ 200,000$ to replace, and a new generator is budgeted at $\$ 2.5$ million.

\section{Losses}

Losses in the power sector represent sales of electricity that did not occur because of damage to the network. Information from BPL indicates that electricity usage in New Providence dropped to near zero on 6 October. Usage recovered to about 75 per cent of the previous peak load one week after the storm, and reached full recovery by the time BPL announced completion of its restoration work on 28 October, as can be seen in Figure 10. Though energy use was lower at the end of October than at the beginning, this is consistent with the seasonal profile of electricity use in past years

Figure 10- Daily peak load readings for New Providence in October

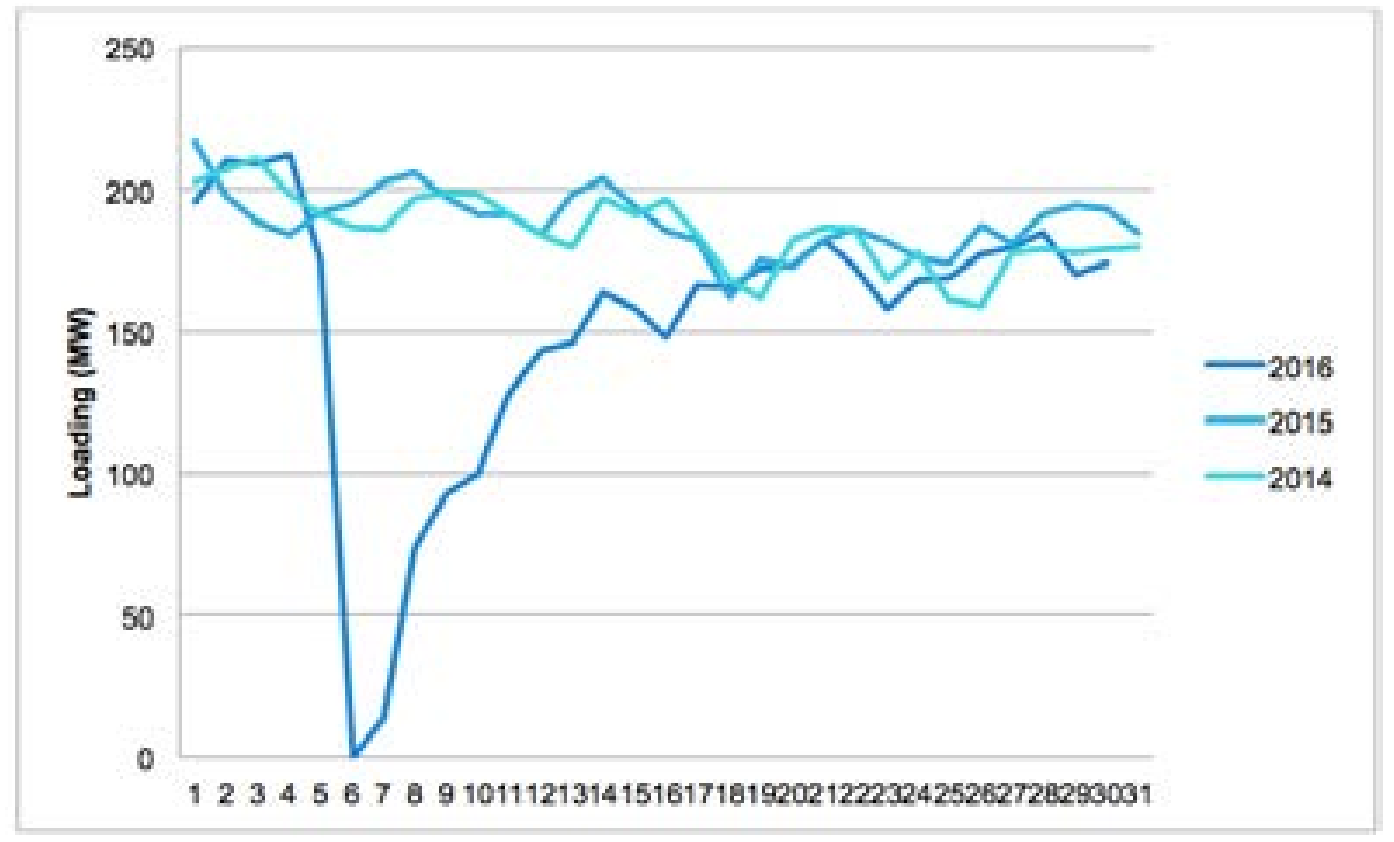

Source: Bahamas Power and Light 
In October, BPL had expected to sell 134,908 megawatt hours ( $\mathrm{mWh}$ ) of electricity, but actually sold $115,830 \mathrm{mWh}$, leaving a shortfall of 19,073 $\mathrm{mWh}$. The value of this loss is calculated based on a retail price of $\$ 0.29$ per kilowatt-hour (kWh). In the absence of data from GBPC, the loss in Grand Bahama (Table 37 ) is estimated based on a similar recovery profile, but calculated over a longer time to reflect the higher damage and slower restoration time in Grand Bahama than in other islands.

Table 37- Estimated loss in the power sector

\begin{tabular}{|l|r|r|r|}
\hline \multicolumn{2}{|c|}{ Description } & \multicolumn{1}{c|}{ Private } & \multicolumn{1}{c|}{ Total } \\
\hline Grand Bahama & & $2,242,936$ & $2,242,936$ \\
\hline New Providence and Family Islands & $5,607,339$ & & $5,607,339$ \\
\hline Total & $\mathbf{5 , 6 0 7 , 3 3 9}$ & $\mathbf{2 , 2 4 2 , 9 3 6}$ & $\mathbf{7 , 8 5 0 , 2 7 5}$ \\
\hline
\end{tabular}

Source: Assessment team, 2016

\section{Additional costs}

Additional costs (Table 38) include the extra labour deployed to perform restoration work, and the support services-such as meals, lodging and transportation-required to maintain the workforce in the field.

As part of the response to this disaster, repair crews were mobilised from throughout The Bahamas, with crews from less affected islands being transported to more affected parts of the country. In addition to linemen, all available staff at BPL were mobilised to work toward the restoration. For example, customer service staff joined crews in the field and took responsibility for communicating with customers, freeing up linemen to focus on repair work.

The Caribbean Electric Utility Services Corporation (CARILEC) organized international crews from elsewhere in the Caribbean including Barbados, Belize, British Virgin Islands, Cayman Islands, Dominica and Grenada to come to The Bahamas to help with restoration. Line repair crews from the United States and Canada also participated in the effort. Approximately 30 crews participated in BPL's restoration effort. 
A second source of additional costs comes from the additional fuel burned by residential generators to provide power in the absence of electricity. Fuel burned by institutionally owned generators such as those operated by hotels or government facilities is accounted for in estimates for other sectors in this document. An estimated 4,000 residential generators were put into use after the Hurricane.

A third additional cost is $\$ 100,000$ allocated for environmental remediation at Clifton Pier Power Station, where some oil was spilled when 55 -gallon drums were knocked over by storm surge. This is further discussed in the environment section of this report.

Table 38- Additional costs in the telecommunications sector.

\begin{tabular}{|c|c|c|c|}
\hline Description & Public & Private & Total \\
\hline Cost of restoration effort & $3,500,000$ & $17,500,000$ & $21,000,000$ \\
\hline Grand Bahama & & $17,500,000$ & $17,500,000$ \\
\hline New Providence and Family Islands & $3,500,000$ & & $3,500,000$ \\
\hline Cost of fuel to residential generators & & $2,520,000$ & $2,520,000$ \\
\hline Grand Bahama & & $1,764,000$ & $1,764,000$ \\
\hline New Providence and Family Islands & & 756,000 & 756,000 \\
\hline Environmental remediation at Clifton Pier & 100,000 & & 100,000 \\
\hline Total & $\$ 3,600,000$ & $\$ 20,020,000$ & $\$ 23,620,000$ \\
\hline
\end{tabular}




\section{Water and sanitation}

\section{Introduction}

Water and sewer infrastructure suffered substantial damage in the islands assessed. In many cases, distribution lines were destroyed or showed leaks and varying degrees of damage to electrical installations, water mains and service connections. This service was suspended in nearly all the affected islands due to the loss of electricity. Damage to infrastructure was considerable in desalination plants in Windsor and Blue Hills. ${ }^{21}$ According to the Water and Sewerage Corporation (WSC), total damage is $\$ 1.2$ million.

Due to the interruption of water distribution service into dwellings, it is estimated that losses are around $\$ 180,600$. Additional costs, estimated as $\$ 578,000$, refer to the expense of managing the debris that arrived at landfills, costs for disaster assessment and recovery teams deployed in several islands, and payment for rented equipment to fulfil restoration work.

Information for this assessment was collected from damage reports and public information provided by WSC, interviews with staff and field visits to affected locations. The section analyses effects of the hurricane in the islands of Grand Bahama, Andros, New Providence and Berry Islands.

\section{Baseline information}

\section{Water and sewerage}

The Bahamas comprises 700 islands and cays, only three- Andros, Grand Bahama and New Providence-have significant water sources. Some have no freshwater at all. Where groundwater is found in natural aquifers, there is concern that the threat of sea level rise can affect the water quality.

According to the 2010 Bahamas Census, approximately 93 per cent of the population has access to piped water-61.74 per cent of connections are to public sector sources and 30.91 per cent are to sources from the private sector (Table 39). Only 1 per cent of the population uses rain water systems.

The Bahamas is one of the countries in the region with a long history of desalination. The primary alternative is groundwater extraction, which is limited. Figure 11 shows the vulnerability of the system, and the reason for concern over the impact of sea level rise on groundwater. 
In The Bahamas, tourism and economic development are dependent on availability of potable water. Therefore, desalination, specifically reverse osmosis (RO) utilizing seawater, is being embraced as the most viable option for the water demand of The Bahamas into the future, particularly given the scale of water production required. Groundwater abstraction can be costly because of the required pre-treatment, and because it requires heavy capital outlay for land acquisition and maintenance. The cost of desalinated water in New Providence is comparable with the cost of barging water from a neighbouring island, and it has the advantage of superior quality, reliability and sustainability. Bringing water from Andros to other islands in water tankers stopped in 2005, in part because of storm damage that raised salinity in the well field.

Table 39- Water supply in private dwellings in The Bahamas

\begin{tabular}{|l|r|r|}
\hline \multicolumn{1}{|c|}{ Water supply } & 63,438 & Percentage \\
\hline Public piped & 1,749 & 61.74 \\
\hline Public piped into yard & 31,763 & 1.70 \\
\hline Private piped into dwellings & 2,920 & 30.91 \\
\hline Private not piped & 1,036 & 2.84 \\
\hline Public stand pipe & 93 & 1.01 \\
\hline Public well or tank & 1,111 & 0.09 \\
\hline Rain water system & 648 & 1.08 \\
\hline Other & $\mathbf{1 0 2 , 7 5 8}$ & 0.63 \\
\hline \multicolumn{1}{r|}{ Total } & & $\mathbf{1 0 0 . 0 0}$ \\
\hline
\end{tabular}

Source: Department of Statistics of The Bahamas, Census 2010

Figure 11- Diagram of vulnerability of groundwater supply

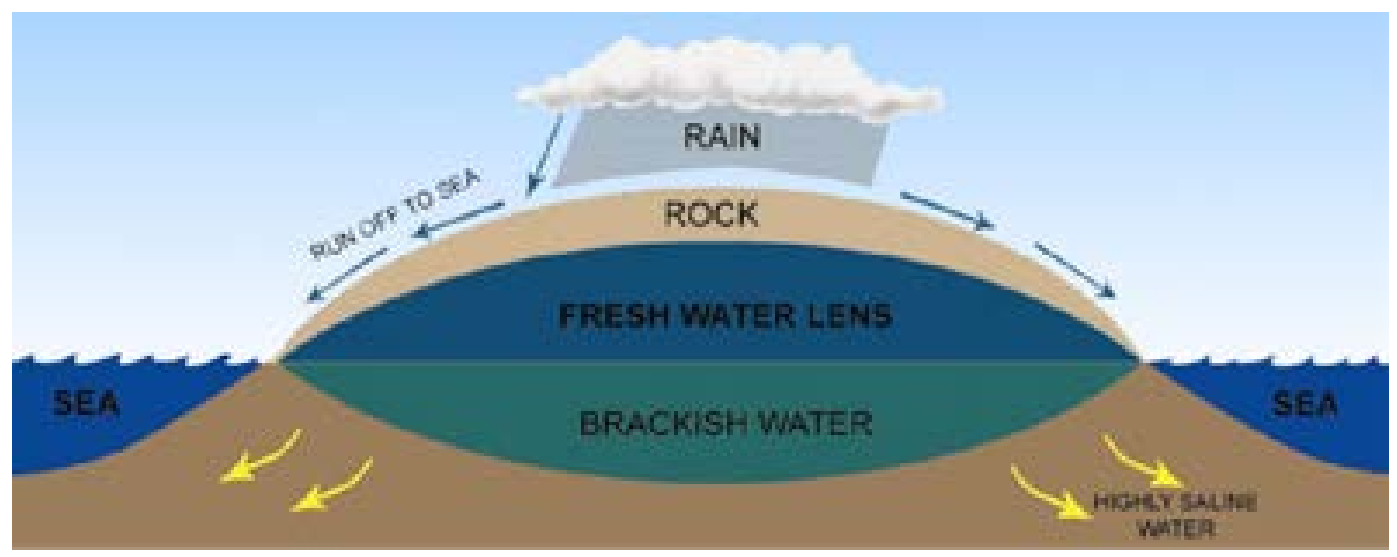


Water produced by RO is not cheap, owing to the pre-treatment and energy requirements of the process, and the fact that returns are poor with respect to serving small, scattered islands, RO continues to replace groundwater sources. In many of the Family Islands, there is no other viable option for water production, so desalination is employed. RO plants currently run on diesel fuel, though some plants in other countries, such as Belize, are able to make use of solar energy to defray this considerable expense.

In some areas, the problem extends beyond the technology and is one of maintenance of the distribution network. In New Providence, for instance, unaccounted for water is estimated to be as high as 50 per cent.

The WSC owns, operates and manages 83 per cent of the country's water systems, while the private sector accounts for the remaining 17 per cent. There is a move toward decentralization and towards increased privatization.

In addition to the WSC, three other major water utility entities operate: Paradise Utility (PU), Grand Bahama Utility Company (GBUC) and New Providence Development Company (NPDC). PU is the sole provider of water for Paradise Island and provides sewerage services as well. GBUC is the sole provider of water in Grand Bahama. NPDC supplies water on demand for WSC and operates a distribution system at the southwestern end of New Providence. The private services are not approved and monitored by the WSC (U.S. Army Corps of Engineers, 2004).

In New Providence, The WSC provides piped water to most sectors of the island, and most of this water is provided through reverse osmosis desalination. Some wellfields in the western end of the island are still in use, but these are being phased out to be replaced by more reliable and better quality water. The WSC system is rapidly being expanded to meet growing demands and new developments.

Blue Hills in Nassau has the largest seawater RO plant designed, built and operating in The Bahamas. Water produced by the facility is sold to the WSC for the public water supply. WSC has demonstrated a preference for private companies to build, own and operate RO plants because of the technical expertise and maintenance required for running these plants. This arrangement reduces the need for technical expertise, minimizing the cost and impact on the human resource capacity of the WSC. The total production of this plant is 12 million US gallons per day. This facility is the largest diesel operated seawater RO desalination plant in the world. 
The plant includes a standby diesel generator, which, along with the diesel driven high-pressure pump, allows the plant to be fully functional even when the normal electric service is down, as occurred during Hurricane Matthew.

Additional to this facility, New Providence has another RO plant located in Windsor Field that produces 2.6 million US gallons per day. This plant has a 6 million US gallons welded-steel reservoir. The total reservoir storage capacity on site is 18 million US gallons.

While active service facilities are not provided in all the islands, areas currently managed under the WSC portfolio include the following communities: North, Central and South Andros, Eleuthera, Abaco, Acklins, Bimini and The Berry Islands, Inagua, Long Island, Mayaguana, Exuma, San Salvador and Rum Cay.

In Andros, the WSC provides water supplies to all communities in North Andros, Mangrove Cay and most of South Andros, using the natural resource, and for 35 years shipped water to New Providence where natural resources were lacking. The main operational base in Andros is located in Nicholls Town with substations in Fresh Creek and the Kemp's Bay complex. The daily water production is approximately of 488,000 imperial gallons.

\section{Sewerage}

Most countries dilute their treated wastes at surface water bodies, such as rivers and lakes, and some use sea outfalls. Significantly, most urban sewage collected by The Bahamas Water and Sewerage Corporation is brackish or saline, mainly because of the use of private wells and infiltration, and this means that it is unsuitable for reuse for irrigation. It is therefore appropriate that the treated effluent be returned to a seawater environment, and just such an environment is conveniently located in the subsurface throughout The Bahamas. The WSC sets stringent requirements and specifications for all disposal wells. Generally, these are based on composition and volume of treated effluents, local hydrology and geology, casing and grout requirements, and the results of pumping tests.

In relation to the sanitation and sewerage systems, the figures presented by the 2010 census show that 83.6 per cent of the population relies on septic tanks and only 12.99 per cent depends on the sewerage system (Table 40). WSC has coverage of 15 to 20 per cent in New Providence, while in the Family Islands WSC treatment is almost non-existent.

Pit latrines and septic tanks are the most common forms of sanitation infrastructure in rural areas. Most systems are constructed by homeowners, who start with a pit latrine and later invest in a septic system. 
Table 40- Sanitation dependence in private dwellings

\begin{tabular}{|c|c|}
\hline System & Dwellings \\
\hline Sewerage & 13,347 \\
\hline Septic tank & 85,903 \\
\hline Pit latrines & 2,191 \\
\hline Other & 1,117 \\
\hline None & 200 \\
\hline Total & 102,758 \\
\hline
\end{tabular}

Source: Department of Statistics of The Bahamas, Census 2010

\section{Solid waste}

The Department of Environmental Health Services is charged with solid waste disposal. Disposal is handled through several landfills, although some rural communities rely on open dumps. In 2010, the average generation of mixed waste was 2,000 tons $(1,814 \mathrm{mt})$ per day, with higher rates recorded in New Providence than in the Family Islands. These higher rates are believed to be a result of the country's dependence on imports, limited recycling capacity and the high volume of tourism-related waste.

\section{Damage}

Water supply was maintained throughout Hurricane Matthew and was at normal levels when the assessment team visited on 27 October. Underground and unreported leaks still appear to be a challenge, but operations have stabilized. Flooding from Hurricane Matthew damaged power transmission and generation, followed by knock-on effects caused by loss of power. This included loss of water treatment and water supply capacities, severe water contamination and no drinking water availability. It also caused loss of sewage disposal facilities. Lack of clean water, combined with human sewage in floodwaters, raises the risk of waterborne diseases. According to the WSC, this sector suffered significant damages to infrastructure and water system lines, including:

- Estimated $\$ 300,000$ for immediate repairs in New Providence. This included damage and restoration costs for supervisory control and data acquisition (SCADA), damage to generators and related equipment, building damages, added fuel costs and other expenses.

- Estimated \$400,000 for immediate repairs in North and Central Andros: These included 800 feet $(245 \mathrm{~m})$ of 4 - and 3-inch pipe; roof damage to old WSC building, replacement of various pumps and fittings, severe roof and flood damage at Pumping Station Office (including electrical equipment), four vehicles and one payloader submerged, electrical repairs and replacement works in WSC wells field, and added fuel and other expenses.

- Damage to storage tank Stevenson estimated at $\$ 500,000$. 


\section{New Providence}

In New Providence, Windsor desalination plant suffered major roof damage, which resulted in damage to some of the plant's electronic equipment. Despite this, production recommenced with some occasional reliability issues. Bahamas Power and Light (BPL) restored power following catastrophic failure of generator; a portable generator was on site for redundancy. Some flooding occurred during a weather of 16 October but operations continue.

Blue Hills desalination plant is operational and producing at 90 per cent of maximum capacity. The pumping station now on primary power from BPL.

In some cases distribution lines were destroyed, showed leaks or were damaged roots when trees were torn from the ground. Water quality may be affected in the longer term if well fields have been contaminated by storm surge.

By 11 October, about 60 per cent of the 113 sewerage lift stations have full BPL power restored. WSC teams continue operating the remaining lift stations using portable generators to mitigate overflows.

\section{Grand Bahama}

In Grand Bahama, sewer systems did not show much damage. Damage to septic tanks was observed, including missing covers, in several affected houses (Figure 12). As in New Providence, some distribution lines were destroyed or showed leaks or were damaged by roots when trees were torn from the ground.

Figure 12- Bathroom and septic tank system affected by flooding in the West End settlement
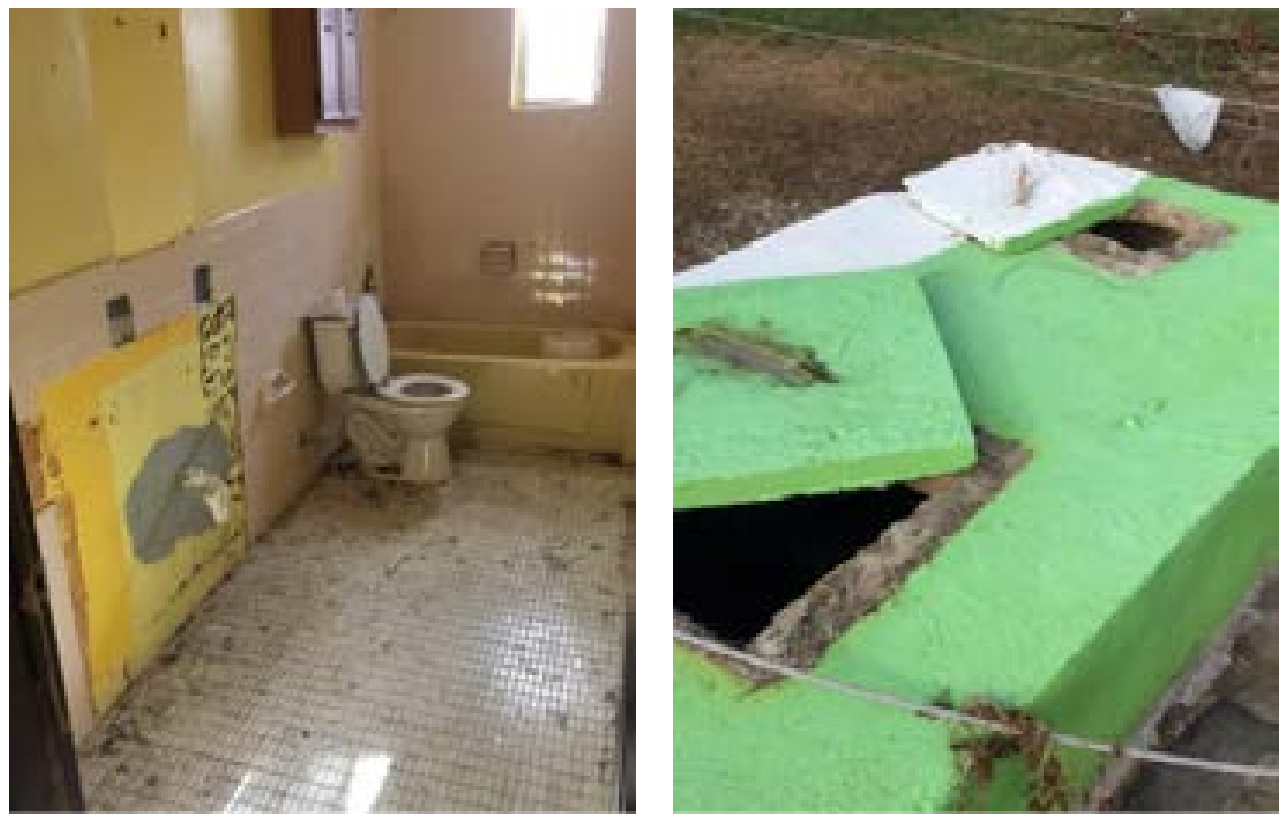


\section{Berry Islands}

Great Harbour Cay well fields reportedly were operational. No major damages were reported.

\section{Andros}

According to NEMA update reports and information from WSC through 11 October, Nicholls Town, Conch Sound and Lowe Sound suffered significant damage and flooding in pumping station serving.

The system serving Nicholls Town and Lowe Sound was partially restored, but high losses affected supply to Conch Sound and Johnson Hill. A team was deployed to detect and repair leaks. Water production was also significantly below normal levels, but an additional generator was deployed and BPL has restored power to parts of the well field. This will increase production to normal levels and remove the need to ration supplies to these communities while leaks are detected and repaired.

In Red Bays, water supply was normalized with generator power. BPL power reportedly is restored and generator will be assigned to assist Mastic Point production. In Mastic Point, water system was operational but production was only about 60 per cent due to many leaks. With reassignment of generator from Red Bays, and with other locations now on BPL power, full production capacity will be restored.

In Stafford Creek, water system is operational on generator. BPL power reportedly was restored 16 October. A team was deployed to resume full operation on primary power.

In Central Andros, BPL has reportedly restored power to all areas from Bowen Sound to Stafford Creek. Cargill, Bowen, Fresh Creek and Love Hill were all on BPL primary power by 11 October. Some gensets will remain in use or on standby at these locations until power supply is fully stabilized. In Staniard Creek, portable gensets are in place but scheduled to be removed and re-deployed following restoration of BPL primary power on 16 October. Leak detection crew has also completed some activities in this area.

Some water lines passed along bridges that were damaged by storm surge.

\section{Losses}

Losses in this sector are related to the interruption in the provision of water for human consumption, sewerage and waste collection. The losses are directly related to the extent of damage suffered by physical assets. Water infrastructure withstood minor damage for the WSC and most WSC facilities could have continued servicing costumers.

However, electricity was interrupted for several weeks throughout the affected islands, thus interrupting the service provided through desalina- 
tion plants and pumps. This was quickly solved with portable generators. Estimated water production cost is normally $\$ 9.50$ to $\$ 10.00$ per 1,000 gallons for desalinised water and $\$ 4.50$ per 1,000 gallons for well water.

Losses in this sector were caused primarily by the interruption in the provision of electricity. This highlights the importance of relying on alternative sources of energy such as portable generators to provide stable service to affected communities.

It is estimated that almost 90 per cent of the population in the islands under assessment were directly affected by the disaster. According to the WSC, there were no significant losses in the water distribution. They reported minor leaks but no quantification was made. Due to the interruption of water distribution service into dwellings, estimated losses are around $\$ 180,600$.

On the other hand, WSC has been improving the water system, so they are trying to win back customers from private wells by offering 50 per cent reduction in the connection fee. Since Hurricane Matthew, they have gained 130 applicants to add to their 44,000 customers. Some people are returning because they lost power for a long time, which meant no pumping of well water.

\section{Additional costs}

Additional costs in this sector are estimated at $\$ 528,009$ based on emergency recovery works in New Providence, Andros, Grand Bahama (Sweet Cay) and the other Family Islands, for the first six weeks after the Hurricane (Table 41). For example, restoration crews were deployed to assist in North and Central Andros along with needed equipment and other supplies. Management of debris for the landfill, resulting from destroyed homes and lost roofs and shingles, represent an additional cost to the solid waste authority of approximately $\$ 278,009$.

A stand-by desalination plant generator was installed in Morgan's Bluff, Andros. It produced 1,000 gallons per hour at a cost of $\$ 5,000$ per day. This system had also been used on Crooked Island after Hurricane Joaquin. Compared to the aftermath of Hurricane Joaquin, the WSC was well-prepared with portable generators to overcome lack of power and use the desalination plant's water storage for several days.

Table 41- Additional costs in the water and sanitation sector

\begin{tabular}{|c|c|}
\hline Item & Cost \\
\hline $\begin{array}{l}\text { Disaster assessment and recovery team, inclusive of immediate } \\
\text { recovery works- Until October } 31 \text { st } 2016\end{array}$ & 250,000 \\
\hline Management of the debris in Landfill & 278,009 \\
\hline Total & $\$ 528,009$ \\
\hline
\end{tabular}

Source: Estimates by disaster assessment team based on information from WSC 


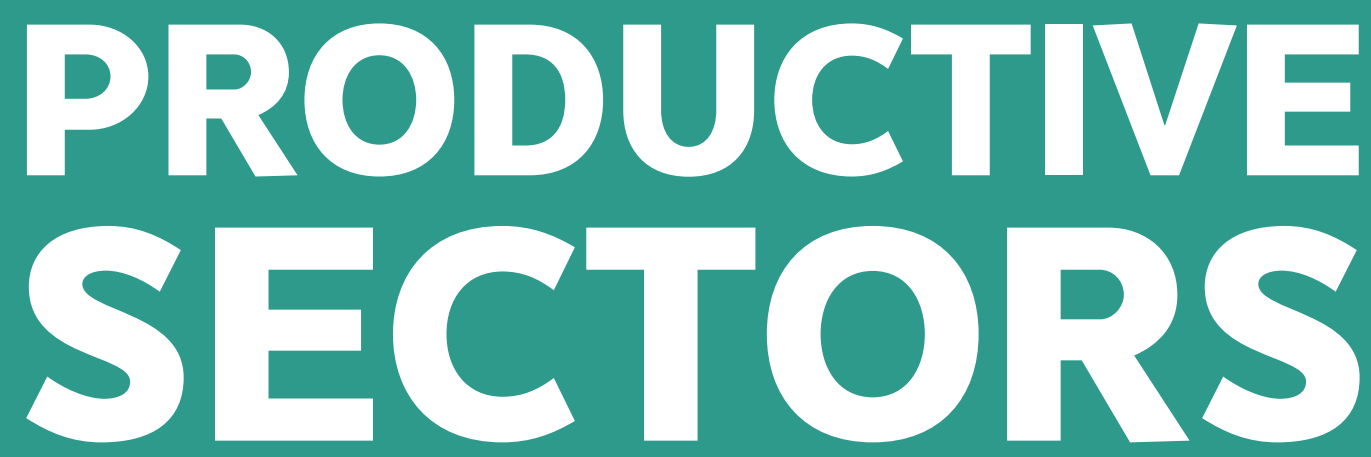




\section{Tourism}

\section{Introduction}

The tourism sector suffered considerable costs because of Hurricane Matthew. The most common physical damage was to roofs and ceilings of tourist facilities and was caused by high winds. This damage was particularly severe on Grand Bahama and in the northern and central districts of Andros. There was also water damage due to wind-broken windows and doors, but most water damage came from storm surges on 6 October. Surges were particularly devastating in areas of North Andros and the West End of Grand Bahama, but they also affected south Nassau. Besides physical damage, the hurricane caused the loss of tourism revenue.

Most of the hurricane risk to The Bahama's tourism sector is due to exposure to storm surge. Because proximity to the sea is critical to the country's tourism industry, the risk of storm surges will continue. Therefore, measures to mitigate the risks and the impacts of water surge in tourism facilities are desirable.

The total estimated cost of Hurricane Matthew to the tourism sector is \$219.2 million. The estimated damage to tourism infrastructure is US\$ 129 million, mostly in Grand Bahama. The estimated losses are \$88.3 million, also the majority of them located in Gran Bahama. It is estimated that 29.8 per cent of the losses will take place in 2017 . The additional cost, primarily debris removal, is estimated at $\$ 1.5$ million..

Grand Bahama accounts for around 75 per cent of the Hurricane's estimated total cost to The Bahamas' tourism sector; New Providence, 21 per cent, and the Out Islands about 4 per cent.

Information for this section comes from the fieldwork observation and interviews, from government institutions including the Ministry of Tourism, Ministry of Finance, The Central Bank of Bahamas, and The Department of Statistics of the government of The Bahamas; and private associations such as The Bahamas Insurance Association.

\section{Baseline information}

Tourism is the main driver of The Bahamas economy. Any disruption can significantly impact all other sectors of the economy. According to the Ministry of Tourism, The Bahamas received 1,483,915 stopover victors during 2015 . It also received 4,051,430 cruise visitors measured by the first port of entry. In addition, according to figures for 2013 from the same source, the country received 47,493 day visitors. In total, the country annually receives more than 6 million visitors; that is more than 16 times its population. 
According to the Ministry of Tourism, visitors to The Bahamas in 2013 spent about $\$ 1.9$ billion. Of this, $\$ 1.38$ billion was spent in New Providence, about $\$ 118$ million in Grand Bahama, and about $\$ 381$ million in the Out Islands. Stopover visitors spend an average of $\$ 1,378$, about $\$ 275$ a day. Cruise visitors spend far less-an average of \$56 per day.

The bulk of the tourist business revolves around Nassau and Paradise Island, where most hotels and resorts are located. In 2014, according to the Ministry of Tourism, New Providence had 8,956 rooms, Grand Bahama, 2,037; and the Out Islands, 4,307.

\section{Damage}

Hurricane Matthew extensively damaged the tourism infrastructure in the northern Bahamian islands. Most damage was to hotels, lodges and resorts, but damage was also significant for tourist operators and related infrastructure such as casinos, restaurants and shops that cater to tourists ${ }^{22}$.

The total estimated tourism-sector damages in The Bahamas are \$129 million (Table 42). About 82 per cent of the damage occurred on Grand Bahama (\$105.9 million). On New Providence Island, the damage is far lower-\$18.4 million-compared to its larger infrastructure. The Out Islands experienced still lower damages $-\$ 5.1$ million. But this amount represents a much greater proportion of the Out Islands' tourism infrastructure, especially in the Northern and Central districts of Andros, compared to the two other islands.

Table 42- Summary of damage in the tourism sector

\begin{tabular}{|l|r|r|r|r|}
\hline & \multicolumn{1}{c}{ New Providence } & \multicolumn{1}{c}{ Grand Bahama } & Out Islands & The Bahamas \\
\hline Roof \& ceiling & $5,268,382$ & $10,955,600$ & $1,325,662$ & $17,549,643$ \\
\hline Rooms & $7,203,300$ & $29,323,905$ & $2,087,150$ & $38,614,355$ \\
\hline Common areas & $3,019,682$ & $45,264,000$ & $1,213,879$ & $49,497,561$ \\
\hline Landscaping & $2,239,648$ & $13,614,331$ & 286,791 & $16,140,771$ \\
\hline Equipment & 380,640 & $3,035,640$ & 146,400 & $3,562,680$ \\
\hline Others & 250,000 & $3,664,240$ & 60,000 & $3,974,240$ \\
\hline \multicolumn{1}{r|}{ Total } & $\mathbf{1 8 , 3 6 1 , 6 5 2}$ & $\mathbf{1 0 5 , 8 5 7 , 7 1 6}$ & $\mathbf{5 , 1 1 9 , 8 8 2}$ & $\mathbf{1 2 9 , 3 3 9 , 2 5 0}$ \\
\hline
\end{tabular}

Source: Assessment team 


\section{Grand Bahama}

On Grand Bahama, the greatest tourism infrastructure damage was to common areas and is estimated at $\$ 45.3$ million. These areas include key facilities of some hotels such as conference rooms, pools, lobbies, gyms, beaches, and so on. This estimate also includes damages in casinos, tour operator facilities, restaurants, and shopping centres.

Estimated damage to tourism-related roofs and ceilings on Grand Baha$\mathrm{ma}$ is $\$ 11$ million. Some properties were severely affected and required complete re-roofing. Still, damage to rooms was nearly three times greater-about $\$ 29.3$ million. This included wind damage to windows and doors, and water damage in a considerable portion of the rooms in some hotels.

The landscaping of many Grand Bahama hotels, lodges, and resorts was severely impacted, and the damage is estimated at $\$ 13.6$ million. Typical damages are uprooted trees and, in some cases, completely ruined gardens. There was also damage to equipment including $A C$ units, power generators, pumps, and other equipment. Finally, the remaining estimated damages on Grand Bahama amount to $\$ 3.6$ million; these include fencing, seawalls, and others.

The combination of big tourist infrastructure and severe storm impact explains why Grand Bahama suffered greater damages than the rest of The Bahamas combined. Many people with whom we spoke during our fieldwork fear a repetition of the aftermath of Hurricanes Frances and Jeanne, which struck The Bahamas in 2004. After those hurricanes, Grand Bahama's then-largest tourist complex-the Bahamas Princess Resort, its casino and International Bazaar-suffered damages from which it never recovered. This was a permanent loss for tourism in Grand Bahama, one that is still very fresh in memory. However, all the businesses we visited expressed a clear disposition to reopen as soon as possible.

\section{New Providence}

On New Providence Island, overall effects of Matthew on the tourism infrastructure were mild. That's because the infrastructure is mainly in northern Nassau and Paradise Island, while the hurricane primarily affected the southern part of New Providence, where a storm surge occurred. Two-thirds of the damage to the tourism infrastructure on New Providence was to roofs and ceilings ( $\$ 5.3$ million) and rooms (\$7.2 million). The rest was damage to common areas, landscapes, equipment and other (\$5.9 million).

\section{Out Islands}

Damages in the Out Islands were concentrated in Andros (Northern and Central districts) and the Berry Islands. The estimated damage to roofs and ceilings is $\$ 1.3$ million. Winds in some areas blew off most or all the 
shingles. In many hotels and lodges, some portions of the roof are a complete loss. The estimated damage in rooms is $\$ 2.1$ million. Besides direct wind and water damage, some hotel facilities were further damaged by the storm surge. Estimated damages for common areas are $\$ 1.2$ million; landscaping, \$286,791; equipment, \$146,400, and other damages, $\$ 60,000$.

These damages seem small compared to Grand Bahama and New Providence, but they are quite large as a fraction of the Out Islands tourist infrastructure. Unlike the rest of the affected islands, some Andros businesses are coming back fairly quickly but others are not, especially in the Northern district. There, some hotels were still being used as temporary shelter for affected residents at the time of our visits.

\section{Losses}

In 2015, when Hurricane Joaquin struck The Bahamas' southern islands, economic losses due to forgone tourist income were around \$1.5 million. Although this toll was high for the affected islands, it was fairly low compared to total tourism income of The Bahamas. Hurricane Matthew, however, affected the two islands most popular with tourists; therefore, losses are greater both in total dollars and as a proportion of the country's total tourism income.

For these estimates we employed official figures provided by the Ministry of Tourism and other information we gathered during our fieldwork. We made some plausible assumptions about the flow of tourists and their behaviour to forecast monthly income. We then estimated reduced income due to Matthew. The loss is the difference between these two estimates. We assume that the flow of tourist income fully recovers after six months, everywhere but Grand Bahama.

Figure 13 displays the monthly forecast of tourist-related income for The Bahamas with and without Matthew, and the difference. For loss of income, the country was fortunate in that Matthew struck during the low season. The high season begins after Thanksgiving. The total estimated loss from October 2016 to December 2016 is $\$ 62.5 .8$ million. ${ }^{23}$ Almost 40 per cent of the loss occurred in October ( $\$ 33.5$ million). From January 2017 to December 2017, estimated loss is $\$ 26.3$ million due to the pace recovery of tourism infrastructure.

Table 43 presents total income losses by type of visitor for New Providence, Grand Bahama, and the Out Islands. By far the greatest loss is in the category of stopover visitors and is estimated at $\$ 78.5$ million. Income loss from cruise visitors is $\$ 9.7$ million and from day visitors is about $\$ 104,000$.

Table 44 depicts estimated losses by type of expenditure and visitor. The greatest forgone income-almost half the total-is accommodation loss from stopover visitors, estimated at $\$ 40.7$. Fewer stopover visitors means lower occupancy in hotels, lodges and resorts. In most 
Figure 13- Income and income losses (\$)

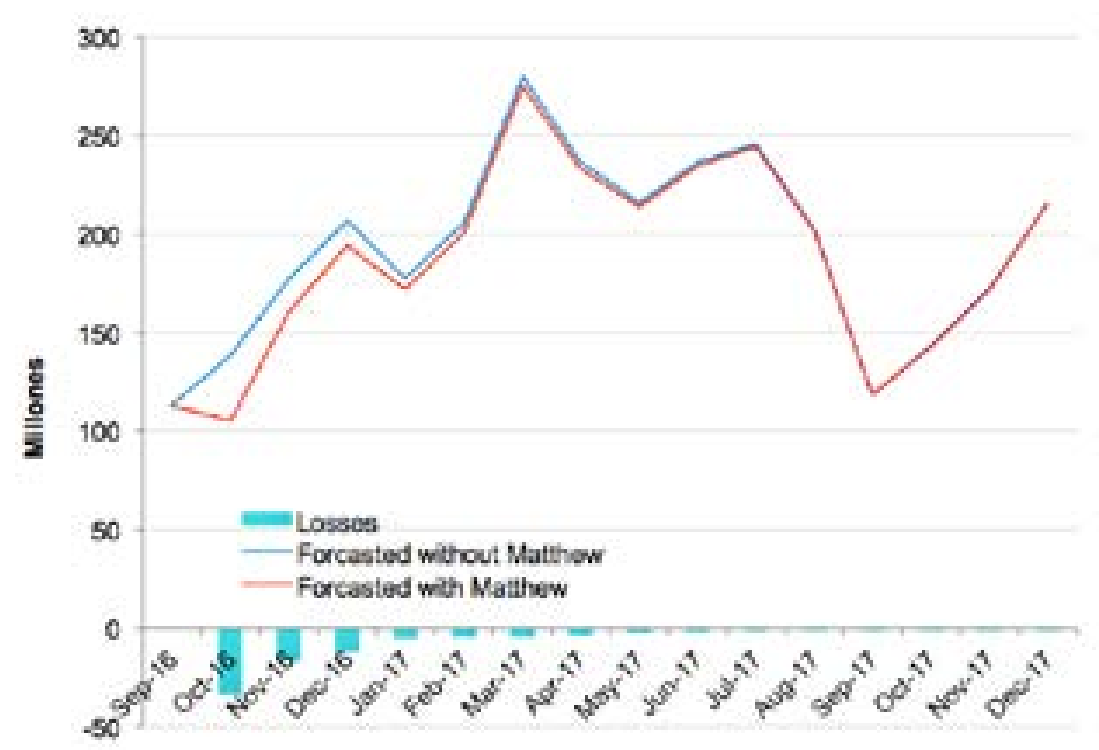

Source: Assessment team

Table 43- Total losses by type of visitor

\begin{tabular}{|l|r|r|r|r|}
\hline & \multicolumn{1}{c}{ Stopover } & \multicolumn{1}{c}{ Gruise } & \multicolumn{1}{c|}{ Day } & \multicolumn{1}{c|}{ Total } \\
\hline New Providence & $25,212,440$ & $2,795,465$ & 15,854 & $28,023,760$ \\
\hline Grand Bahama & $50,817,138$ & $6,620,329$ & 77,718 & $57,515,185$ \\
\hline Out Islands & $2,510,632$ & 257,948 & 10,224 & $2,778,804$ \\
\hline \multicolumn{1}{|c|}{ The Bahamas } & $\mathbf{7 8 , 5 4 0 , 2 1 0}$ & $\mathbf{9 , 6 7 3 , 7 4 3}$ & $\mathbf{1 0 3 , 7 9 7}$ & $\mathbf{8 8 , 3 1 7 , 7 4 9}$ \\
\hline
\end{tabular}

Source: Assessment team

Table 44- Total losses by type of expenditure

\begin{tabular}{|c|c|c|c|c|}
\hline & Stopover & Gruise & Day & Total \\
\hline Accommodation & $40,743,433$ & 0 & 0 & $40,743,433$ \\
\hline Meals and Drinks & $12,775,141$ & $1,149,129$ & 12,231 & $13,936,501$ \\
\hline Activities & $5,892,064$ & $3,296,940$ & 36,459 & $9,225,463$ \\
\hline Shopping & $8,162,595$ & $4,392,341$ & 46,579 & $12,601,514$ \\
\hline Transportation & $3,789,152$ & 481,321 & 5,075 & $4,275,548$ \\
\hline Casino & $5,432,254$ & 345,757 & 3,126 & $5,781,137$ \\
\hline Other & $1,745,571$ & 8,254 & 327 & $1,754,153$ \\
\hline Total & $78,540,210$ & $9,673,743$ & 103,797 & $88,317,749$ \\
\hline
\end{tabular}

Source: Assessment team 
places, including Grand Bahama and Andros (North and Central Districts), the loss in stopover visitors is due to limited capacity until the hotels, lodges and resorts restore full operations.

The second- and third-greatest income losses also are foregone expenditures by stopover visitors: meals and drinks ( $\$ 12.8$ million) and retail shopping (\$8.2 million). Spending on tourist operators is reduced an estimated $\$ 5.9$ million, since fewer tourists mean fewer tourism activities. Casino businesses are estimated to suffer a loss in revenue of $\$ 5.4$ million. Part of this loss is due to the fact that some casinos are closed, and will remain closed for a few more weeks. Transportation services related to tourism are estimated to experience a loss of $\$ 3.8$ million. Loss in the other tourism-related expenditures by stopover visitors is estimated at $\$ 1.7$ million.

\section{New Providence}

According to the Ministry of Tourism, Nassau and Paradise Island have 58.5 per cent of The Bahamas' total room capacity. Nassau and Paradise Island are where the country's major hotels and resorts are located. However, the damages of Matthew to the tourist infrastructure were proportionally much lower in New Providence than in Grand Bahama and Andros (Northern and Central Districts).

But even though the tourism infrastructure in New Providence was not deeply affected, the amount of lost tourism income is disproportionately large. New Providence accounts for about 41 per cent of The Bahamas' projected total losses in the tourism sector.

Ninety per cent of the $\$ 28$ million (Table 45 ) in tourism losses in New Providence is related to the drop in stopover visitors. Most of this loss occurred in October.

The major loss is in accommodation, estimated at $\$ 14.3$ million, followed by meals and drinks at $\$ 4.1$ million, shopping at $\$ 3.3$ million, and casinos at $\$ 2.7$ million. The tourist operators are estimated to lose $\$ 2.1$ million, transportation $\$ 1.1$ million and the rest of the sector about $\$ 416,000$.

\section{Grand Bahama}

Hurricane Matthew hit Grand Bahama particularly hard. While having a much smaller tourist infrastructure and business income than New Providence, Grand Bahama suffered proportionally greater losses, and the recovery will take more time.

The total losses on the island are estimated at $\$ 57.5$ million. Almost 90 per cent of this loss is due to the drop in stopover visitors, but about 11 per cent ( $\$ 6.6$ million) is due to lost visits by cruise ships (Table 46$)$. 
Tourist operators and commercial sales are particularly sensitive to this drop. The room capacity of Grand Bahama was severely damaged. Major hotels and resorts were affected, and some will remain closed until the end of 2017.

The losses in accommodation are $\$ 25$ million, followed by restaurants and related business at $\$ 9.4$ million. Foregone revenue by shopping is estimated at $\$ 9$ million and by tourist operators is $\$ 6.8$ million. The transportation business is estimated to suffer losses of $\$ 3$ million. Casinos are estimated to lose $\$ 3$ million in revenue. The other tourism expenditure losses are estimated at about $\$ 1.3$ million.

Table 45- New Providence losses by type of visitor

\begin{tabular}{|c|c|c|c|c|}
\hline & Stopover & Gruise & Day & Total \\
\hline Accommodation & $14,310,581$ & 0 & 0 & $14,310,581$ \\
\hline Meals and Drinks & $3,791,951$ & 352,229 & 1,998 & $4,146,177$ \\
\hline Activities & $1,308,526$ & 754,776 & 4,281 & $2,067,582$ \\
\hline Shopping & $1,875,806$ & $1,378,164$ & 7,816 & $3,261,786$ \\
\hline Transportation & 958,073 & 156,546 & 888 & $1,115,507$ \\
\hline Casino & $2,551,499$ & 153,751 & 872 & $2,706,122$ \\
\hline Other & 416,005 & 0 & 0 & 416,005 \\
\hline Total & $\$ 25,212,440$ & $\$ 2,795,465$ & $\$ 15,854$ & $\$ 28,023,760$ \\
\hline
\end{tabular}

Source: Assessment team

Table 46- Grand Bahama losses by type of visitor

\begin{tabular}{|c|c|c|c|c|}
\hline & Stopover & Gruise & Day & Total \\
\hline Accommodation & $25,040,141$ & 0 & 0 & $25,040,141$ \\
\hline Meals and Drinks & $8,629,932$ & 765,431 & 8,986 & $9,404,349$ \\
\hline Activities & $4,337,195$ & $2,458,461$ & 28,861 & $6,824,517$ \\
\hline Shopping & $6,046,386$ & $2,893,070$ & 33,963 & $8,973,419$ \\
\hline Transportation & $2,613,185$ & 311,362 & 3,655 & 2,928,202 \\
\hline Casino & $2,880,755$ & 192,006 & 2,254 & $3,075,016$ \\
\hline Other & $1,269,544$ & 0 & 0 & $1,269,544$ \\
\hline Total & $50,817,138$ & $6,620,329$ & 77,718 & $57,515,185$ \\
\hline
\end{tabular}

Source: Assessment team 


\section{Out Islands}

Estimated tourism losses on the Out Islands is \$2.8 million (Table 47) and occurs mainly in Andros Island's Northern and Central Districts and The Berry Islands. Half the losses are in accommodation. This is especially crucial for Andros, where hotels and lodges suffered severe damages. There are doubts if some lodges will be able to recover from the hurricane.

Andros tourism relies heavily on flats fishing and other activities that estimated to experience a loss of $\$ 333,365$. Every person we spoke to with knowledge of the fishing business discarded the idea that the hurricane damaged any fisheries.

Other estimated losses in the Out Islands are meals and drinks, $\$ 385,975$; shopping, \$366,310; and transportation, \$231,839.

Table 47- Out Islands losses by type of visitor

\begin{tabular}{|c|c|c|c|c|}
\hline & Stopover & Gruise & Day & Total \\
\hline Accommodation & $1,392,711$ & 0 & 0 & $1,392,711$ \\
\hline Meals and Drinks & 353,258 & 31,470 & 1,247 & 385,975 \\
\hline Activities & 246,343 & 83,704 & 3,318 & 333,365 \\
\hline Shopping & 240,403 & 121,107 & 4,800 & 366,310 \\
\hline Transportation & 217,894 & 13,413 & 532 & 231,839 \\
\hline Casino & 0 & 0 & 0 & 0 \\
\hline Other & 60,023 & 8,254 & 327 & 68,604 \\
\hline Total & $\$ 2,510,632$ & $\$ 257,948$ & $\$ 10,224$ & $\$ 2,778,804$ \\
\hline
\end{tabular}

Source: Assessment team

\section{Additional costs}

Additional costs of Hurricane Matthew to The Bahamas' tourism sector are associated with debris removal, estimated at $\$ 1.5$ million (Table 48). Grand Bahama accounts for 82 per cent of debris-removal costs.

Table 48- Summary of additional costs in the tourism sector

\begin{tabular}{|c|c|}
\hline & Cost \\
\hline New Providence & 211,597 \\
\hline Grand Bahama & $1,219,887$ \\
\hline Out Islands & 59,001 \\
\hline The Bahamas & $\$ 1,490,485$ \\
\hline
\end{tabular}

Source: Assessment team 


\section{Fisheries}

\section{Introduction}

In 2015, at current prices, the fishing sector makes up 0.94 per cent of the gross domestic product (GDP) of The Bahamas. This sector provides full-time employment to an estimated 9,300 commercial fishers and a few hundred more people in vessel maintenance, fish processing, retail and trade. The fishing fleet is characterized as small-scale and counts approximately 4,000 fishing vessels ranging in length from 10 to 100 feet ( 3 to $30 \mathrm{~m}$ ) but generally are less than 23 feet $(7 \mathrm{~m})$. Information in this sector is difficult to get because boats under 20 feet $(6 \mathrm{~m})$ are not licensed, making them difficult to track. ${ }^{24}$

For the evaluation of this sector, since the evaluation team was not provided with aggregate damage information, the procedure was as follows. First, through on-site interviews and visual inspection, the team obtained on the destruction of assets in Lowe Sound in North Andros and West End in Grand Bahama. Both areas were severely affected. Production of the fisheries in both villages is mainly done by small-scale fishers. This group will be called "small fishing." This group can be seen as study cases and not as a sample to make an inference.

The second set of information used in this assessment is based on the sector's aggregate production data for 2016. It is reasonable to assume that fishery assets were not harmed but that their production flow may be altered due to effects of the hurricane. We call this group "other fisheries" and will estimate mainly the losses to this group.

Estimated total damage in small fisheries is $\$ 833,500$. Losses from small fishing are $\$ 422,057$ and from other fisheries $\$ 20.6$ million. Total losses are $\$ 21$ million. Additional cost is mainly related to debris removal. Our estimate for it is $\$ 25,000$.

\section{Baseline information}

The total commercial fisheries production in 2015 was estimated at nearly 13,200 tons (12,000 tonnes). The production has fluctuated in recent years, largely due to variations in landings of spiny lobster. For example, nearly 11,000 tons (10,000 tonnes) of spiny lobster were landed in 2010 and 2012 and about 7,150 tons (6,500 tonnes) in 2015. 
Spiny lobster stocks in The Bahamas are being fully exploited, while conch, snappers and groupers are, as in the rest of the Caribbean, under heavy fishing pressure and some stocks are probably overexploited. Major threats to The Bahamas' marine fishery resources are coastal zone development, boat and diver damage to reefs, over-harvesting of commercial species and disturbance to sensitive sites.

Exports of Bahamian fish and fisheries products have gradually reduced over the last 6 years, from tons 2,996 tons (2,718 tonnes) in 2009 to 2,642 tons (2,397 tonnes) in 2015. A reduction in exports of spiny lobster is also visible. Since 2013 the combined exports of spiny lobster (meat, whole and live) have been below 2,200 tons (2,000 tonnes).

The fisheries sector is a major contributor to reducing the trade deficit of The Bahamas. The volume of imports of fishery products is some 75 per cent higher than the volume of exports. But the trade balance for fish and fisheries products is positive, with export earnings of around $\$ 70$ million and imports around $\$ 24$ million. Exports of fish and fisheries products in 2015 accounted for 31 per cent of the domestic exports of The Bahamas.

Approximately 90 per cent of all lobster caught are exported overseas. Most lobster tails are exported to the United States (64 per cent) with France next accounting for approximately 28 per cent of this product. Ten processing plants are licensed to export lobster (Marine Resources Assessment Group, 2009). The product bought by these plants is supplied mostly by mothership-dory companies that maintain its high quality. The frozen product is then carefully thawed and re-processed by the processing plants into different size categories. Lobster and other fishery products are also transported from the Family Islands to New Providence, the main domestic fisheries market, by approximately 23 mail boats that operate between New Providence and the Family Islands on a weekly basis.

The latest (2013) per capita fish supply figures indicate that Bahamians have a supply of fish and fisheries products of about $31 \mathrm{~kg} /$ capita per year. In 1990 this figure was only $23 \mathrm{~kg}$. The increase in supply of fish to the population has largely been achieved through an increase in fish and fishery product imports. Fish and fisheries products provide about 10 per cent of the total protein intake by the Bahamian population. 
The fisheries sector development in The Bahamas has been hampered by the lack of a proper legal, policy and planning framework. This matter has been addressed by the recently drafted Fisheries Act, the draft National Policy, and the Strategic Plan for Fisheries and Aquaculture Development and Management in The Bahamas 2017-2022. Fisheries sector governance in The Bahamas is also constrained by the limited availability of data and information for management and development of capture fisheries (commercial and recreational).

Commercial fishing takes place on the continental shelf, mainly on the Great Bahama Bank and Little Bahama Bank. These two banks make up most of the $116,550 \mathrm{~km} 2$ of continental shelf area in Bahamian waters. The continental shelf is nearly 18 per cent of the total Exclusive Economic Zone (EEZ) of The Bahamas of 654, $719 \mathrm{~km} 2$.

\section{Damage}

The total damage in Lowe Sound and West End is estimated at $\$ 833,500$ (Table 49). One of the most severely affected areas of the fisheries sector was North Andros. Fishing is a critical part of the livelihoods of North Andros inhabitants. Most operators in the sector are small artisanal fishers, and all are affected. Our estimates assumed that fleet is affected by 90 per cent.

The estimated total damage in North Andros is $\$ 665,500$. Among other gear destroyed by the hurricane, about one-third of North Andros lobster traps were lost. But 60 per cent of the damage was to facilities: the hurricane destroyed a fish market as well as a lobster tail processing plant.

At West End in Grand Bahamas, fishing gear and vessels were destroyed and a processing plant was damaged. Vessels accounted for 76 per cent of the damage in that location. 
Table 49- Damage to small fisheries

\begin{tabular}{|c|c|c|c|}
\hline Asset & Andros & Grand Bahama & Total \\
\hline Traps & 40,500 & 13,500 & 54,000 \\
\hline Vessels & 225,000 & 127,500 & 352,500 \\
\hline Facilities & 400,000 & 27,000 & 427,000 \\
\hline Total & $\$ 665,500$ & $\$ 168,000$ & $\$ 833,500$ \\
\hline
\end{tabular}

Source: Assessment Team, 2016

\section{Losses}

\section{Damage to Small Fisheries}

For estimating losses, we focus on the period October to December 2016. For small fisheries, our estimates depend on the damage suffered by the fleet. This is an important constraint for the fast recovery of the production. Losses for small fisheries are estimated for lobster, conch and other species. ${ }^{25}$

In Andros, total losses are estimated at $\$ 300,858$ (Table 50). Lobster account for 58 per cent of the total, followed by other species, 34.3 per cent. In Grand Bahama, total losses are $\$ 121,198$. Lobster account for 56 per cent; other species, 35.8 per cent. Andros accounts for 71 per cent of the losses.

Table 50- Small fisheries losses, October to December 2016 (\$).

\begin{tabular}{|l|r|r|r|r|}
\hline \multicolumn{2}{|c|}{ October } & & \multicolumn{1}{c|}{ Tovember } \\
\hline North Andros- & & & \\
\hline Lobster & 68,656 & 62,602 & 43,024 & 174,282 \\
\hline Conch & 12,555 & 7,560 & 5,859 & 25,974 \\
\hline Other species & 22,599 & 25,272 & 52,731 & 100,602 \\
\hline Subtotal, North Andros & $\$ 103,810$ & $\$ 95,434$ & $\$ 101,614$ & $\$ 300,858$ \\
\hline & & & & \\
\hline Grand Bahama- & & & & \\
\hline Lobster & 22,885 & 23,476 & 21,512 & 67,873 \\
\hline Conch & 4,185 & 2,835 & 2,930 & 9,950 \\
\hline Other species & 7,533 & 9,477 & 26,366 & 43,376 \\
\hline Subtotal, Grand Bahama & $\$ 34,603$ & $\$ 35,788$ & $\$ 50,808$ & $\$ 121,199$ \\
\hline \multicolumn{1}{r|}{ Total } & $\mathbf{\$ 1 3 8 , 4 1 3}$ & $\mathbf{\$ 1 3 1 , 2 2 2}$ & $\mathbf{\$ 1 5 2 , 4 2 2}$ & $\mathbf{\$ 4 2 2 , 0 5 7}$ \\
\hline
\end{tabular}




\section{Other Fisheries}

Several factors could affect fishing activity of producers whose boats were not damaged. Among them were electric power losses, damages to fishers' homes, and movement of larger vessels to safe areas. Such factors contribute to a decrease in the number of departures of the fishing boats that began days before the hurricane's arrival. To make this estimate we assumed that departures of fishing vessels declined 40 per cent during October. Under this assumption, losses are $\$ 20.6$ million. Total losses are about $\$ 21$ million.

\section{Additional costs}

The additional costs are mainly related to debris removal. Our estimate for it is $\$ 25,000$. 

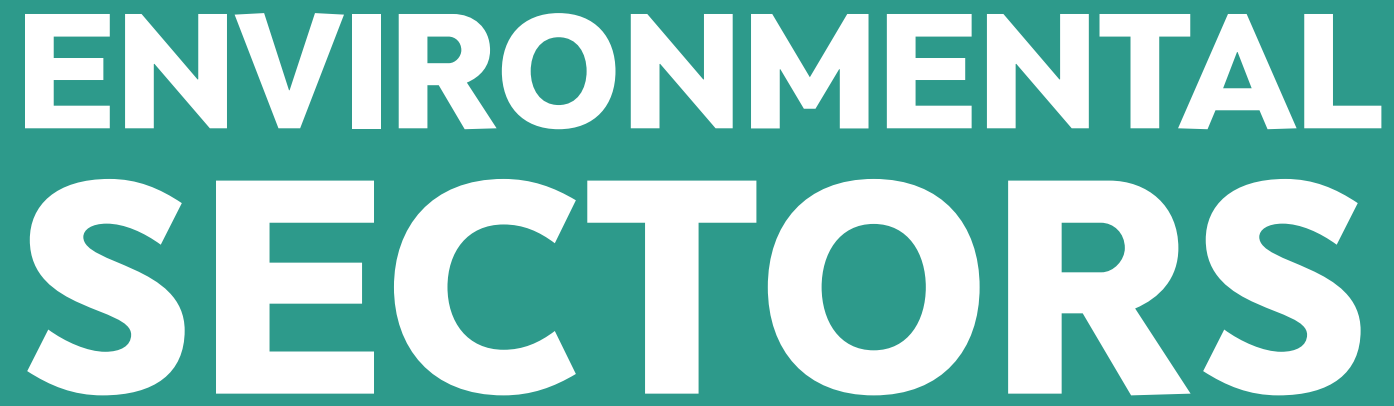


\section{Environment}

\section{Introduction}

Coral reefs, seagrass meadows, beaches, mangrove forests and native broadleaf forests in The Bahamas have adapted over time to become resilient to tropical weather. The wave action, storm surge and high winds that occurred during Hurricane Matthew caused a wide range of damages to those ecosystem types, with the brunt of the damages occurring in pockets of native hardwoods/coppice forests and other non-pine species including fruit trees. Other coastal ecosystem types including coral reefs, beaches, mangrove marshes and seagrass meadows appeared to have fared very well during the storm event.

While there was visual evidence that some seagrass meadows were damaged on Grand Bahama and Andros, seagrasses in the Caribbean have a tendency to recover quickly from tropical storm events. The resource should recover quickly, but the damage to seagrasses beds is likely to have short- to medium-term effects ( 2 to 4 years) on the services they provide to lobster and conch fisheries. ${ }^{26}$

Visual inspections of three coral reef areas revealed that while the sediment around the reefs was either missing or more abundant, the reefs fared well in the high currents and waves produced by Matthew. There was some fragmentation of the softer and branching corals at reefs south of Nassau and south of New Providence, but the damage appeared minimal.

The observed mangrove areas on New Providence and Andros also fared well from the storm surge, flooding and wave action. Mangrove trees are well adapted to these tropical storm events, and the trees likely prevented or lessened storm damages to adjacent property.

The most damaged natural resource appears to be native hardwoods and other non-pine tree species in New Providence, Grand Bahama andprimarily-Andros. Forests in The Bahamas are valued less for their marketable timber and more for important services they provide to the Bahamian economy and ecology.

The estimated damage in the environment sector is approximately \$1.7 million. These damages are a product of the impacts on coral reefs and beaches and on the infrastructure of protected zones. Losses are estimated at $\$ 72,364$ and additional costs at approximately $\$ 4.4$ million.

26. The value of these services is not estimated due to lack of assessment data. Lobster and conch utilize seagrass beds for reproduction, foraging and seeking refuge. These services were likely disrupted in localized areas around the impacted islands. Seagrasses throughout the Bahamian islands provide other services including nutrient cycling, sediment stabilization, carbon sequestration, food for sea turtles, and preventing shoreline erosion (Clavelle et al. 2013). However, these services are not likely to have been disrupted by Matthew. 


\section{Baseline information}

Natural resources of The Bahamas help foster the capital on which its economy depends. Rich soils, subtropical climate, coral reefs, seagrasses, mangroves and broadleaved forests all contribute to the tourism and trade industries that make up most of the country's annual gross domestic product. With so much depending on the health of natural resources, disruptions on any scale can have an impact on the quality of life for Bahamians.

Available baseline information on ecosystems of The Bahamas has long been studied by non-government organizations (NGOs), academic institutions and the government. Due to the sheer extent of seagrass beds, coral reefs, mangroves and forests, many of the areas studied are in protected areas, proposed protected areas, or localized groups of islands. All habitat types exist outside those protected areas, but data on habitat extent and health in unprotected areas are limited.

In total, The Bahamas archipelago includes 3,000 islands with land area of $13,860 \mathrm{~km} 2$ and sea area of $286,140 \mathrm{~km} 2$. The archipelago supports a population of more than 335,000 people (Hargreaves-Allen 2010). Of the land area, $2,651 \mathrm{~km} 2$ (19 per cent) is protected through conservation programs. Only $1,622 \mathrm{~km} 2$ (less than 1 per cent) of the total marine area is protected. Protected areas in The Bahamas include: ${ }^{27}$

- 16 Marine protected areas

- 27 national parks

- 2 marine managed areas

Protected areas tend to generate large revenues for agencies charged with their operation. The revenue generated from the protected areas of The Bahamas is no exception. Several national and international NGOs have placed values on services provided by Bahamian natural resources such as coral reefs, beaches, seagrass, mangrove swamps, wetlands, saltmarshes and forests. Two reports calculated values for two protected areas-Retreat Gardens in Nassau and Exuma Cays Land and Sea Park-and for Andros Island (Hargreaves-Allen and Pendleton 2010; Hargreaves-Allen 2010). The habitats provided an estimated \$279 million in economic impact to the Bahamian economy in 2009. They are expected to generate approximately $\$ 5$ billion over 25 years. The economic impacts of Exuma and the Retreat are estimated at 41 and 22 times, respectively, larger than their operating costs (Hargreaves-Allen, 2010 and Hargreaves-Allen and Pendleton, 2010)

Baseline data from Bahamian protected areas varies widely in detail, scope and age. Additionally, the methods of data collection make comparisons difficult. Regardless, the baseline conditions in The Bahamas remain relatively healthy and abundant because of the resilient nature of the habitat types. Many natural resources in The Bahamas are valued and studied for their contributions as commodities, rather than as ecosystems that provide services to humans and nature. For example, 
seagrass beds are considered for their ability to provide habitat for lobster and conch larvae; and beaches are monitored for the availability of tourism activities. Several valuation reports of ecosystems in The Bahamas have been written, but the baseline data is not typically gathered to show economic contribution-unlike baseline data collected for other sectors such as agriculture, tourism or infrastructure. Where possible, this report uses valuation studies that focus on services that nature provides to people and the economy.

This report assumes that, before Hurricane Matthew, the health of the resources was generally good except for some coral reefs. For example, a recent report indicates that only half the reefs in New Providence and the Rose Islands are in fair to good condition. The other half are in poor condition, which makes them more susceptible to threats such as tropical storm events (Dahlgren 2014). It is further assumed that other threats to the health of natural habitats existed before the hurricane including climate change, sea-level rise, development and over-fishing.

Table 51 summarizes the environmental impact values, estimated to total about $\$ 8,409,014$, because of the hurricane.

Table 51- Estimated cost to environmental sector

\begin{tabular}{|c|c|c|c|}
\hline & Public & Private & Total \\
\hline Damages & $1,702,150$ & 175,500 & $1,877,650$ \\
\hline Losses & 72,364 & 0 & 72,364 \\
\hline Additional Costs & $4,459,000$ & 0 & $4,459,000$ \\
\hline Total & $\$ 8,233,514$ & $\$ 175,500$ & $\$ 8,409,014$ \\
\hline
\end{tabular}

Source: Assessment team 2016

\section{Damage}

\section{Grand Bahama}

National parks:

Grand Bahama is home to three national parks: Rand Nature Centre, Peterson Cay National Park and Lucayan National Park. Peterson Cay was inaccessible due to field conditions. Rand and Lucayan were assessed for damages. Damages (and in parentheses, repair or restoration status) are listed as follows:

- Lucayan National Park

- Power lines blocked entrance to driveway and parking area (removed on 27 October)

- Trees and other debris on parking lot and trails, and parking lots, blocking access to park features 
- Kiosk and signage knocked over (re-positioned)

- Amenities on trail broken (unknown)

- Extensive dune erosion (no corrective action taken)

- Mangrove boardwalk damaged (repaired but needs additional stabilization)

- $\quad$ Rand Nature Centre

- Trees and debris on parking lot, trails, pond, arboretum, near front gate and near welcome centre. (debris removed from trails, near front gate and welcome centre, but not from pond and arboretum)

- New wooden gate around dumpster knocked down. (unknown repairs)

o Sections of park boundary fence knocked down or damaged. (unknown repairs)

o Viewing deck roof and animal cages damaged. (unknown repairs)

Non-protected areas:

Outside the National Parks, a driving tour around the southern and western areas of Grand Bahama showed that many native hardwoods and fruit trees were severely damaged by high winds. Among the downed hardwoods, there now exists a greater chance of wildfires, which could pose threats to inhabited areas, causing costs associated with response. The ECLAC team encountered a wildfire in a forested area damaged by Matthew that did not appear to be controlled at that time.

Four other areas encountered during the driving tour included primarily Caribbean pine (Pinus caribaea var. bahamensis) trees that suffered almost zero damage from Matthew. The pine savannahs appear to have burned from prescribed or accidental fire within the last three years. The taxi driver indicated that local law enforcement and fire officials conduct controlled burns to prevent wildfire and to discourage illegal growing operations. While pine trees are generally more elastic and can bend under high winds, prescribed fire is known to make forests more resilient to human induced and natural events that could harm them otherwise. The limited damage to Caribbean pine trees-throughout Freeport and other parts of Grand Bahama-is likely attributable to the burning of many areas by local police and fire officials.

Coral reefs:

One area of coral reef was inspected at a location adjacent to the south shore of Grand Bahama near Freeport known as Shark Junction. The reefs in this area appear to have fared well despite Hurricane Matthew. Some of the branching and softer corals, including sponges, appear to have been knocked off the reef sites, as small pockets of broken corals had accumulated between reef heads. These pockets contained both live coral knocked off by the storm and dead coral that had perished 
previously. The damage, however, was minimal. Divers with Underwater Explorers Society (UNEXSO) remarked that large volumes of sand were missing, as reef heads protruded from the sand by approximately 3 feet (1 $\mathrm{m}$ ), exposing the necks of the coral patches. The boat captain remarked that he thought the sand moved north towards Grand Bahama and created a sand bar approximately 330 feet $(100 \mathrm{~m})$ from the shoreline. There was a sandbar at this location, but it was not determined whether the storm produced it.

\section{Beaches:}

On the west end of Grand Bahama, near the seawall near the intersection of Beachway Drive and Silver Point Drive, the beach had been armoured with large boulders and recycled concrete. Sand in this area had remained in place. Some fragments of dead coral had washed up on this beach, but it appeared to be a mix of long dead coral and newly fragmented coral and sponges.

The Rapid Needs Assessment (RNA) of Grand Bahama conducted by NEMA from 9 to 11 October 2016, reports significant loss of sand at Smith Point Beach, Taino Beach, Coral Beach and Lucayan caused by Matthew. Sand dunes at Coral Beach and Smith Point Beach were impacted by storm surge resulting in a 3.3-ft $(1 \mathrm{~m})$ loss in height of the dunes. Sand volume was not estimated in the RNA. However, using that information and rough calculations from aerial imagery, Table 52 shows that these areas would require an estimated $30,783 \mathrm{yd} 3(23,535 \mathrm{~m} 3)$ of sand fill between the impacted areas. Cost would be about $\$ 1,385,235$, based on $\$ 45$ per cubic yard $(\$ 59 / \mathrm{m} 3)$.

Table 52- Estimated damage to beach dunes, Grand Bahama

\begin{tabular}{|c|r|r|r|}
\hline \multicolumn{2}{c}{ Location } & \multicolumn{2}{c|}{ Sand fill required } \\
\multicolumn{1}{|c|}{$(\mathbf{y d 3})$} & 12,197 & 9,325 & 548,865 \\
\hline Smith Point Beach and Taino Beach & 6,486 & 4,959 & 291,870 \\
\hline Lucayan Beach & 12,100 & 9,251 & 544,500 \\
\hline Coral Beach $\quad$ Total & & & $\mathbf{\$ 1 , 3 8 5 , 2 3 5}$ \\
\hline
\end{tabular}

Source: Assessment team 2016 
Seagrass:

ECLAC team members noted long ridges of washed-up, submerged aquatic vegetation (SAV) at the wrack line along the beaches on the West End, Grand Bahama. A similar observation was made along the eastern shoreline of northern Andros. SAV is extensive in The Bahamas, and while the volume of sea grasses washed onto the beaches appeared large, the biomass is likely insignificant relative to the large areas of seagrass beds located offshore. Damage estimates to submerged aquatic vegetation (SAV) are unknown at this time, as there have been no official reports of damage, no field surveys of SAV beds and very little anecdotal evidence that damage has occurred. SAV can be damaged by hurricanes, intense wave energy and significant sediment deposition. Despite the lack of surveys, it is likely that the hurricane had some impact on the SAV beds. It is known that cumulative impacts of repeated tropical storms can begin causing significant reductions in the ecosystem services that seagrasses provide, such as habitat for commercial and non-commercial fish and shellfish species and improving water clarity.

\section{New Providence}

National parks:

The four national parks on New Providence are Primeval Forest, Harrold and Wilson Ponds, the Retreat and Bonefish Pond. According to The Bahamas National Trust (BNT) Hurricane Matthew Damage Report (BNTDR), all four parks received damages. The known damages and repair status, according to BNT staff, are as follows:

- The Retreat -

- Large trees and palms uprooted and broken

- Rock wall broken by fallen trees (trees removed, wall needs repair)

o Water pump, holding tank and pipes adjacent to Pavilion damaged (temporarily repaired)

- Roof above dining room and kitchen damaged by large tree (tree removed)

- Debris blocking driveways, walkways, trails and covering lawns (cleared and removed)

- $\quad$ Primeval Forest National Park -

- Large trees uprooted, broken and covering trails and key sinkholes in park (cleared and removed)

- Wooden railings along the pathway damaged by fallen trees and limbs, blocking bathroom and welcome centre. (cleared and removed) 
- Harrold and Wilson Ponds National Park -

o Western pavilion, access ramp, boardwalk, boardwalk railing, eastern boardwalk junction, support pilings and beams collapsed or destroyed. (no corrective action to-date)

- Bonefish Pond National Park -

- Boardwalk near parking lot, main pavilion and staircase have been structurally damaged. (no corrective action todate)

BNT staff indicated that Harrold and Wilson Ponds suffered the most infrastructure damage. They estimate the cost of repairing and replacing the structures at $\$ 100,000$. Repairs at Bonefish Pond are estimated at $\$ 60,000$, and damage at the Retreat is estimated at $\$ 3,000$. While mangroves at Bonefish Pond fared well from Matthew, all large hardwoods and coppice were severely damaged or destroyed.

Coral reefs:

ECLAC personnel interviewed staff from Stuart Cove's Dive Bahamas (SCDB) during the visit in New Providence about the condition of coral reefs in their dive territories and coral nurseries that they manage. While SCDB staff have yet to conduct full assessments, they indicated that two nursery sites were damaged by Matthew. The two sites, James Bond and Yellow Buoy, suffered 75 and 34 per cent losses respectively. The dive staff estimate that each nursery site will cost about $\$ 10,000$ to rebuild. This includes collecting coral fragments, adhesive glue, staff time and transportation to and from the sites over a two-year period to ensure proper growth of the corals.

SCDB damage estimates to coral reefs are anecdotal at this time; however, the dive staff reported that some dive sites south of New Providence suffered damages. The Pumpkin dive site appears to have lost sponges and soft corals, as well as what staff described as a boulder that smashed through some of the reefs.

Staff also indicated that a 20- to 10 -inch (0.5- to $0.25-\mathrm{m})$ layer of grey, unconsolidated mud was present over many of the dive sites including Pumpkin, Mike's Reef, Shark Site, Power Plant and Will and Lori's Wreck. The mud, described as silty, floating material, causes poor visibility. ECLAC personnel saw the silt during two brief snorkel trips near the power plant and to its east. According to staff accounts, the mud was thickest northwards, and thinned out southwards. Razorback dive site, approximately 6 to 10 miles (10 to $16 \mathrm{~km}$ ) south of New Providence, had much less mud. Persistence of the mud in these areas could damage corals, but the mud will likely migrate or dissipate as normal currents move it. 
The SCDB facility was damaged by Matthew, causing the facility to close for four days after the storm. The owner spent $\$ 98,000$ in materials and labour to repair buildings, docks and other parts of the facility, and estimated that repairing the remaining damages will cost an additional $\$ 50,000$. The SCDB facility lacked Bahamian electricity for 10 days. During that period, SCDB used approximately 2,100 gallons of diesel fuel costing about $\$ 7,500$ to power a generator. Mangroves:

ECLAC personnel observed several areas of mangroves along the southern coast of New Providence; however, no damage was apparent from these observations.

\section{Beaches:}

Beaches on the south side of New Providence bore the brunt of wind and wave action from the storm. While erosion was discovered at south-facing beaches on Grand Bahama, the RNA report states that minimal erosion occurred on New Providence. Many beaches received additional sand because of Matthew. During the snorkel trip to the reef adjacent to the Clifton Pier Power Station, ECLAC personnel saw several knockedover trees of Australian pine (Casuarina equisetifolia), an invasive species, along sandy beaches and dunes. The trees' large root mats were exposed, and these areas are likely to experience erosion from the loss of stabilizing roots. The recommendations in this report will include the removal of this invasive species from the coastal zone in order to limit these impacts in the future.

\section{Andros}

National parks:

Andros is home to five national parks: West Side, Crab Replenishment Reserve, North and South Marine Parks and Blue Hole National Park. Damage assessments could not be conducted, but ECLAC personnel and BNT staff visited Blue Hole and other areas in central and north Andros on 25 October to observe impacts from Matthew.

Prescribed forest fires are not conducted or allowed on Andros and most places in The Bahamas, but natural or human-induced fires have occurred on many tracts of Caribbean pine in Blue Hole and in areas outside the protected zones. These tracts of pine trees appeared to be intact and suffered little or no storm impact. Most of the observed areas of coppice and other native hardwoods were severely damaged inside Blue Hole National Park, near settlements along the east and northern coast of northern Andros, and the east coast of central Andros north of Fresh Creek.

Blue Hole National Park consists of approximately 40,000 acres of mostly Bahamian pine savannah with pockets of coppice forests scattered throughout, accounting for approximately 7 to 10 per cent of the total 
forest cover. Stands of pine trees fared exceptionally well, but the observed coppice stands had significant damages ranging from complete destruction to approximately half the trees blown over. Coppice forests contain a large number of tree and brush species that support numerous species of reptiles, insects and birds. Throughout the areas in Blue Hole along the main road and in communities that were observed, large tracts of pine trees had been burned in accidental forest fires or possibly prescribed fire. The burning has contributed to their resilience in the face of the hurricane. An enhanced fire risk, however, exists in Blue Hole, especially around coppice areas where abundant leaf litter and dead trees and vegetation add fuel to future fires.

The staff building at Blue Hole suffered shingle loss and a small leak. Estimates for repairs to replace shingles and repair interior damages are approximately $\$ 3,000$ for materials and $\$ 3,000$ for labour. Additionally, some roads and trails are blocked by debris.

Non-protected areas:

Natural resource impacts in northern and parts of central Andros varied widely. Erosion of sandy beaches was minimal based on observations from locals. As on Grand Bahama, large linear piles of SAV were seen on the shoreline in Staniard Creek settlement. Damage assessments to seagrass meadows and coral reefs had not been conducted at the time of this assessment and are not considered in damage estimates. Conducting follow-up damage assessments will be included in the recommendations of this report.

Love Hill and Fresh Creek - These settlements have a significant percentage of the coppice forests in central Andros. Most of the coppice species were stripped of leaves, broken at the trunks, had their crowns twisted off, or were completely uprooted and lying on the ground. Trees and structural damage around the power station and Fresh Creek Bridge were extensive. Mangroves and vegetation on the shoreline along Fresh Creek appeared intact with minimal to zero damage. Roads have been cleared of debris and are passable, although several areas still had significant debris left untouched or in piles.

Lowe Sound - The northernmost tip of Andros suffered extensive wind, water and wave damage from the hurricane. Houses, businesses and infrastructure are close to and in some cases directly on the shoreline. The boat ramp and businesses on the ramp are on a man-made peninsula that protrudes into the water. The storm destroyed these buildings, and much of the debris was washed across the road and into the undeveloped bushland area behind the homes. Many homes on the west side of the road were also destroyed. Debris has been mostly removed from the road; however, it has not been removed from the community due to lack of excavation and transportation equipment, and lack of a suitable disposal area. Furthermore, much vegetation debris is mixed with construction debris and other household waste, increasing the difficulty of debris removal, transport and disposal. The seawall appeared mostly in- 
tact; however, the storm surge was too high for the structure to mitigate wave action. Most large native trees and coppice areas were uprooted or snapped. The area had almost a total loss of medium to large trees. The commercial fishing industry suffered extreme damage, as many locally owned boats were destroyed; the businesses supporting the boat ramp were wiped out. The local fish house, where fish was stored, was also destroyed.

Staniard Creek Settlement - As in other parts of northern Andros, the storm destroyed most native trees and coppice areas in Staniard Creek. Homes and other structures received significant damages. Roads are clear, but tree and construction debris remain abundant. The shoreline near the BNT office is sandy and appeared to have survived well considering storm's high winds and wave action. As observed along the shoreline on the West End of Grand Bahama, a significant amount of seagrass was washed ashore. The seagrass mound was approximately 20 feet wide, 6 inches high and more than 1,000 feet long ( $6 \mathrm{~m}$ by $15 \mathrm{~cm}$ by $>300 \mathrm{~m}$ ). Morgan's Bluff, Nicholls Town, Conch Sound and Mastic Point - These coastal settlements suffered very similar damages to buildings and trees. Many of the larger coppice trees were severely damaged or destroyed. Tree and construction debris is mostly removed from roadways, but still prevalent in yards and empty lots. Beaches in these settlements appeared to have fared well despite wave and wind action, although a substantial amount of plant debris lay on the shorelines. This included some seagrass material, but less than at Staniard Creek beach.

Red Bays - The shoreline seemed mostly unharmed by wave and wind action, although the area was struck by a 7- to 9-foot (2.1- to 2.7-m) storm surge that deposited debris in trees more than 500 feet $(152 \mathrm{~m})$ from the shoreline. Mangroves and other trees and bushes did not suffer damage or lose leaves. Some larger native trees near the boat launch were toppled or broken, but the extent of this damage was minimal compared to areas on the east side of the island.

\section{Summary}

Without environmental assessments of the extent of damages to Bahamian coastal habitats, estimating the damages is impossible. Scientific and economic studies of the value of the natural resources over the past decade in The Bahamas have placed values on the contributions and services that habitats provide. Producing damage assessments on the condition of seagrasses, coral reefs and coppice forests, in one or some of areas affected by Matthew would present a starting point for understanding the costs of the destruction across the country. Table 53 presents estimates for damages that were specifically mentioned by RNA assessments, the BNT assessment, and through interviews and observations by the ECLAC team. 
Table 53- Summary of damage to the environmental sector.

\begin{tabular}{|c|c|c|c|}
\hline Description & Public & Private & Total \\
\hline Coral reefs & & 175,500 & 175,500 \\
\hline Beaches & $1,385,235$ & & $1,385,235$ \\
\hline \multicolumn{4}{|l|}{ National parks } \\
\hline Infrastructure in protected areas & 163,000 & & 163,000 \\
\hline Total & $\$ 1,548,235$ & $\$ 175,500$ & $\$ 1,723,735$ \\
\hline
\end{tabular}

Source: Assessment team 2016

\section{Losses}

Ecosystems in The Bahamas have endured tropical storm damages over thousands of years. Effects of Hurricane Matthew on these ecosystems are largely unknown. But services that these ecosystems provide to the Bahamian economy are substantial, and any disruption in them can be reflected in:

- Economic losses in coastal properties from damage to mangroves, seagrass and beaches.

- Lost eco-tourism revenue resulting from damage to dive shops and boats, coral reefs, commercial and recreational fish habitat, forest habitat for birds and endangered species, etc.).

- Limited access to clean water because of damaged forests, streams, rivers, greenspace, etc.

Losses in this section (Table 54) are calculated by the potential lost direct revenue from closures of national parks, UNEXSO and the Stuart's Cove Dive Bahamas. The national park estimates are derived from estimates in the Hargreaves-Allen 2010 Bahamas valuation report, which uses Retreat Gardens as a case study.

Table 54- Losses to environmental sector for selected ecosystem areas

\begin{tabular}{|l|r|r|}
\multicolumn{2}{|c|}{ Place Name } & \multicolumn{2}{c|}{ Days } \\
closed \\
\hline Grand Bahama & & \\
\hline Rand Nature Centre & 15 & 6,870 \\
\hline Lucayan National Park & 21 & 9,618 \\
\hline New Providence & & \\
\hline The Retreat & 21 & 9,618 \\
\hline Primeval National Forest Park & 21 & 9,618 \\
\hline Harrold and Wilson Ponds NP & $>40$ & 18,320 \\
\hline Bonefish Pond NP Total & $>40$ & 18,320 \\
\hline & $\mathbf{1 3 7}$ & $\mathbf{\$ 7 2 , 3 6 4}$ \\
\hline
\end{tabular}

Source: Assessment team 2016 


\section{Additional costs}

\section{Debris removal}

Clean-up activities throughout The Bahamas have been slow and difficult for all the agencies and Ministries involved. Roadsides, temporary dumpsites and residential yards have significant volumes of debris because of a lack of dumpsites, loading equipment, transport vehicles, hand tools and wood chippers. According to Ministry of Environment and Housing (MEH) officials and NEMA personnel, who are primarily responsible for debris management, much debris is a mix of organic material (trees, bushes, etc.), demolition debris from homes and businesses and household trash. Government officials and BNT staff have stated that it is preferred to have chainsaws and wood chippers onsite during organic debris management activities, but this equipment is limited and in high demand.

Debris handling and disposal are costly in The Bahamas due to the limited availability of heavy machinery, transport trucks and the lack of available landfill capacity. In New Providence, for example, NEMA has indicated spending an average of $\$ 43,000$ weekly for up to 12 weeks for debris removal and landfill management. Assuming that about half the debris is organic, the additional public costs of debris removal and disposal on New Providence, Andros and Grand Bahama islands are estimated as \$258,000 per island (Table 55).

Table 55- Estimated cost of debris removal and disposal.

\begin{tabular}{|c|c|}
\hline Island & Public \\
\hline Grand Bahama & 258,000 \\
\hline New Providence & 258,000 \\
\hline Andros & 258,000 \\
\hline Total & $\$ 774,000$ \\
\hline
\end{tabular}

Source: NEMA, Assessment team, 2016

\section{Oil spill}

At Clifton Pier Power Station in southwest New Providence, Hurricane Matthew damaged an oil storage area used for holding previously spilled oil. The damaged caused a release of approximately 900 gallons of petroleum products into the ocean. The costs associated with recovery and remediation of the new spill are estimated at $\$ 100,000$. This cost is included in the power sector. This estimate, however, reflects only the immediate remediation activities, which includes containment and recovery of the spilled fuel and oil. It does not account for total remediation, monitoring, and addressing the longer-term implications of chronic oil spills such as polluted soil, groundwater, storm water runoff, and damages to adjacent marine habitats including sandy shorelines, coral 
reefs and important aquatic species that utilize these areas throughout various life stages.

In January 2015, Prime Minister Perry Christie announced that \$10 million was being allocated to study and mitigate the existing "environmental degradation at Clifton Pier" (Tribune, 30 January 2015). According to the Tribune article, the $\$ 10$ million allocation was directed towards massive oil-soil extractions and oil-water preventative measures; however, at the time of Hurricane Matthew it was unclear if any of the remediation operations have begun.

Public and private resources are at risk from the chronic oil spill identified in this area. Beaches adjacent to Clifton Pier are open to the public for recreational activities such as hiking, fishing, swimming and snorkelling. In addition, nearby private diving and snorkelling companies utilize coral reefs immediately offshore from the power plant and within 385 yards $(350 \mathrm{~m})$ of the shoreline for tours and coral reef restoration projects. ECLAC personnel snorkelled at this location and saw a slight oil sheen on the surface of the water and smelled petroleum in the air. Coral reefs adjacent to the spill site are vulnerable to environmental conditions due to their poor health. Some areas on the coral reef are dead from bleaching, as well as littered with large tires and other debris. This area of coral reef should be studied for any potential hydrocarbon impacts that could affect growth, survival and reproduction.

According to a paper by Mark Cohen titled A Taxonomy of the oil Spill Costs, the average cost of oil spill clean-up in the US, in 2010 is approximately $\$ 16$ per gallon, which puts the cost of the clean-up of 900 gallons at $\$ 14,400$ (Cohen 2010).

\section{Fire threats}

Hurricane Matthew hit The Bahamas at the end of the wet season, which typically occurs from May through October. Wildfires tend to become widespread during the dry season, which runs from November through April. The large numbers of trees destroyed by the hurricane act as a fuelling agent to fires, causing them to become extremely difficult to contain, thus making built infrastructure more vulnerable. A comprehensive fire-control strategy should be developed and implemented as soon as possible for all islands in The Bahamas, but especially on Andros, New Providence and the Grand Bahama since those suffered significant numbers of destroyed trees.

Downed trees should be removed or mulched as soon as possible, especially in areas that are near critical infrastructure or settlements or that have high biological value. While it is not practical to revegetate areas where trees are removed, this land should be treated and monitored to prevent colonization by invasive species while allowing for the progression of native species. 
Prescribed fire activities should be allowed in areas with large tracts of wilderness. Recently, Forestry and BNT staff participated in wildland fire training on Abaco with equipment donated by The Nature Conservancy. This training program, using similar equipment, should be repeated and offered on Andros and Grand Bahama. Table 56 presents estimated one-time costs of fire control activities for all three islands, based on interviews with Nature Conservancy staff.

Table 56- Estimated cost of prescribed wildland fire strategy

\begin{tabular}{|c|c|}
\hline Fire Strategy & ost \\
\hline Invasive Species Control & $3,000,000$ \\
\hline Fire Control Equipment & 75,000 \\
\hline Training Contractor & 60,000 \\
\hline Fire Activities & 150,000 \\
\hline Total & $\$ 3,285,000$ \\
\hline
\end{tabular}

Source: Interviews with staff of The Nature Conservancy

\section{Comprehensive assessments}

Assessments of natural resources should occur as soon as possible. The types of assessments that should occur include the investigation of damages to seagrass meadows, coral reefs, beaches and forests. Monitoring efforts should have identical methodologies for comparison purposes, and they can be accomplished with the help of academic institutions and NGOs that operate in these areas.

Comprehensive assessments of each habitat type will cost approximately $\$ 100,000$ per island, based on estimates of similar operations in the United States and Belize following natural disasters. Therefore, the total cost of assessments for Andros, New Providence and the Grand Bahama is approximately $\$ 300,000$. These assessments will help direct further studies and restoration project potential for The Bahamas.

\section{Additional costs summary}

The discussion in the Additional Costs includes estimates based on the most critical operations that should occur in the short-term for the areas of The Bahamas most impacted by Hurricane Matthew. Table 57 shows the total additional costs to the environment sector. 
Table 57- Additional costs to the environment sector.

\begin{tabular}{|c|c|c|c|}
\hline Additional Costs & Public & Private & Total \\
\hline Organic debris removal & 774,000 & 0 & 774,000 \\
\hline Clifton pier oil spill & 14,400 & 0 & 14,400 \\
\hline Fire threats & $3,285,000$ & 0 & $3,285,000$ \\
\hline $\begin{array}{l}\text { Comprehensive environmental } \\
\text { assessments }\end{array}$ & 300,000 & 0 & 300,000 \\
\hline Total & $\$ 4,373,400$ & $\mathbf{0}$ & $\$ 4,373,400$ \\
\hline
\end{tabular}

Source: Assessment team, 2016 
MACROECONOMIC

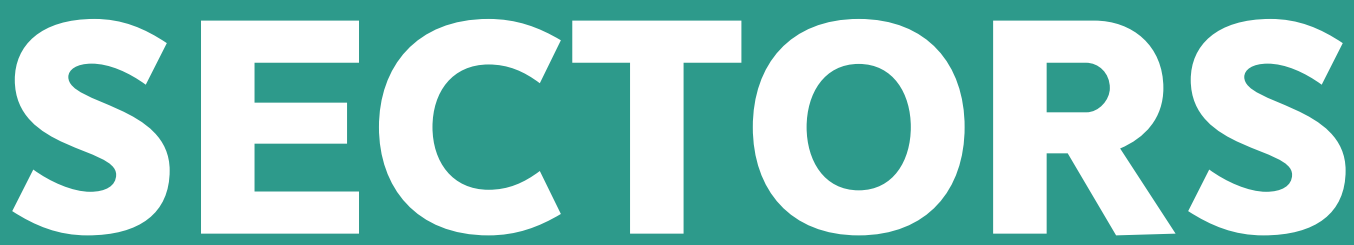




\section{Economic impact}

\section{Evolution of the economy before Hurricane Matthew}

\section{Economic Activity}

During the last three years, economic growth in The Bahamas has either been flat or negative. Nevertheless, over the short to medium-term as the economy rebounds, bolstered by reconstruction and a pickup in tourism with expected opening of the mega BahaMar Resort in 2017, higher growth is expected to facilitate fiscal consolidation and a more sustainable debt profile.

Before Matthew, relative to a decline of 1.7 per cent in 2015, the economy was projected to recover with growth of 0.5 per cent in 2016 . The rebound in activity was expected to be driven by higher tourist arrivals and spending. Tourism value added was projected to rebound based on increased arrivals of high-spending stopover visitors and cruise ship passengers.

Indictors pointed to mild recovery in the economy during the first seven months of 2016, compared with the similar period last year. Stopover visitor arrivals increased by 2.7 per cent to just over 1 million visitors. Similarly, cruise passenger arrivals rose by 1.5 per cent to 2.8 million visitors. However, indicators also point to lower average room revenues, which offset somewhat total expenditure in the sector.

The construction sector posted a modest recovery during the first half of the year. The number of building starts in New Providence and Grand Bahama increased by 21 per cent to 127 and in value by 7.6 per cent or $\$ 28.6$ million. There was softness in the sector in the second quarter, evidenced by slow down activity in foreign direct investment. Nevertheless, overall for the first half of the year activity picked up in the sector. Despite the fallout from postponement of the opening of the Baha Mar Resort, a number of workers got seasonal jobs related to Carnival and other cultural events. This led to a fall in the unemployment rate by 2.1 percentage points to 12.7 per cent.

The rate of inflation remained subdued at 0.6 per cent year-on-year to June, mainly reflecting low international fuel prices. The average price of housing, water, gas, electricity and other fuels fell by 1.5 per cent. Nevertheless, with the recent pickup in international fuel prices, the price of gasoline and diesel has started to trend upwards. 


\section{Fiscal developments}

Sustainable fiscal balances and public debt have evolved as one of the most important concerns in The Bahamas after the global crisis. In the face of weak private sector response, the government was forced to undertake fiscal stimulus to maintain growth and employment during the crisis. This led to a sharp increase in public debt. This challenge has been aggravated by relief and reconstruction spending from Hurricane Joaquin last year and now Hurricane Matthew. Nevertheless, the government has embarked on a fiscal consolidation programme which combines the 7.5 per cent VAT with improved revenue administration and contained growth in expenditure. In line with this, the budget for $2016 / 17$ projects an overall deficit of 1.1 per cent of GDP.

The budget for 2016/17 was aimed at maintaining progress with fiscal consolidation. A fiscal deficit of 1.1 per cent of GDP ( $\$ 100$ million) is projected. Although there will be some overshooting of this target in the wake of Hurricane Matthew, momentum towards fiscal consolidation is expected to continue in the short term. In 2016/17, priorities centre on medium- to longer-term structural reform to increase revenues and to contain growth in expenditure, especially government consumption spending. Buoyed by VAT receipts, tax revenue is projected to increase to 22.5 per cent of GDP, while total revenue is projected to rise to 23.7 per cent of GDP.

\section{Monetary developments}

The financial sector, both onshore and offshore, is vital to the economy of The Bahamas. Therefore, the level and quality of financial intermediation affects investment in productive activity and economic growth. In recent years, financial sector developments have been marked by sluggish growth in credit to the private sector, high excess liquidity in the banking system and high levels of non-performing loans. These reflect in part the lay-over effects of the global crisis, which had led to significant loan defaults, owing in part to higher rates of unemployment, more intense prudential regulation and increased screening of borrowers.

During the first nine months of 2016, growth in domestic credit slowed to $\$ 113.5$ million, compared with $\$ 123.6$ million in 2015 . This reflected a credit slowdown in both the public and private sectors. Growth in credit to the public sector eased to $\$ 116$ million. Meanwhile, credit to the private sector, which had contracted on average by 1.1 per cent over the last six years, declined by $\$ 30.4$ million, reflecting continued weak business confidence and debt deleveraging by enterprises affected by the global crisis. Credit quality of the banking sector was affected by the global crisis, but has been slowly improving in recent years. During the first nine months of 2016, credit quality continued to strengthen. Total private sector loan arrears declined by 5.5 per cent or $\$ 66.7$ million. The 
improvement was led by a 5.7 per cent (\$51.4 million) fall in loan arrears in excess of 90 days. With the increase in loan loss provisions, the ratio of provisions to non-performing loans and arrears improved by 5.2 and 3.7 percentage points respectively.

On the liabilities side, Bahamian dollar deposits expanded $\$ 140.3$ million to $\$ 217.2$. This largely reflected a spike (\$285.8 million) in holdings of demand deposits. The spike was linked to a one-off transaction by the telecommunications company. Meanwhile, reflecting low interest rate environment and savers' time preference, the rate of increase in savings slowed and time deposits contracted by $\$ 135.6$ million.

The banking system has been challenged by the loss of correspondent banking relationships by some operators, including banks and money transfer providers. This is affecting banking sector costs, trade and the ease of conducting international financial transactions. Further, the loss of money transfer services would affect remittance outflows from The Bahamas to countries such as Haiti and Jamaica.

\section{Balance of payments}

As a small open and extremely import-dependent economy, The Bahamas tends to run structural current account deficits that are financed by capital inflows. Fortunately, over the years, much of these inflows have been in the form of foreign direct investment, which results in transfer of modern technology, production capacity-especially in the hotel sector-and managerial skills. All are critical to the development process in the country. Since 2010, the structural current account deficit has averaged over 16 per cent of GDP, underscoring the heavy dependence on foreign financing.

Data for the first half of 2016 indicated that the current account deficit declined sharply by 43.4 per cent ( $\$ 323.6$ million) in nominal terms, from 16.8 per cent of GDP in first half of 2015 to 9.3 per cent of GDP for the similar period of 2016. This outturn stemmed from a sharp reduction in the merchandise deficit. The deficit reduction was owed mainly to sharp import compression because of (1) lower imports of construction materials with the winding down of work on major projects including the Baha Mar Resort and (2) reduced payments for oil imports with the fall in international fuel prices. Indeed, the average cost of aviation gas and propane for domestic use contracted 61.9 per cent and 7.3 per cent respectively.

The important services account surplus narrowed by 11.7 per cent. This was headlined by a major reversal of the small inflows to the government in 2015 to an outflow of $\$ 118$ million in 2016. Net tourism receipts fell slightly, 0.2 per cent. 


\section{Impact of Hurricane Matthew on the macro-economy}

\section{Impact on GDP and Prices}

The impact on the GDP growth rate is a reduction of 1.1 percentage points. Before Hurricane Matthew, the projected GDP growth rate for 2016 was 0.5 per cent. Following this disaster, based on estimates of losses and additional costs, a GDP decrease of 0.6 per cent is projected. Consistent with this result, the payroll of the economy would be decreased by $\$ 17.9$ million, of which 76.5 per cent, or $\$ 13.7$ million dollars, represents a decrease in payroll in the tourism sector.

The loss of capital income, which includes the operating surplus (remuneration to the formal sector) and mixed income (remuneration to the informal sector), is $\$ 37.7$ million, explained mainly by a $\$ 17.1$-million reduction to income of formal entrepreneurs in the tourism sector (hotels and restaurants) and the \$15.8-million contraction of income of individual entrepreneurs in the fishing sector.

Although inflation in The Bahamas is mainly imported inflation owing to the extreme openness of the economy, the hurricane is expected to lead to higher domestic prices. This would result from the severe impact on the small domestic agriculture and fisheries sector, which is expected to lead to food shortages from these sources. In addition, supply-side constraints in the labour market and for construction materials could lead to higher prices in the construction sector.

\section{Fiscal Impact of Hurricane Matthew}

The fiscal fall-out will be one of the main impacts of Hurricane Matthew. Table 58 presents government revenues and expenditures for the years 2012 to 2016, alongside projections for the periods just before and just after the hurricane struck.

As noted before, the government had already embarked upon a fiscal consolidation programme to achieve primary surpluses to stabilise the public debt. The strategy entailed a mix of boosting revenues through introduction of the VAT, strengthened revenue administration and collections, and improved expenditure management, targeting and productivity. Hurricane Matthew will derail the consolidation efforts in the short term, as the substantial financial impact of the hurricane leads to significant unbudgeted expenditure on relief and reconstruction. 
Table 58- Impact of Hurricane Matthew on government fiscal operations. Revenues and expenditures of the central government

\begin{tabular}{|c|c|c|c|c|c|c|}
\hline & & Projec & ions & & & \\
\hline & & & & & $\begin{array}{l}\text { Before } \\
\text { Matthew }\end{array}$ & $\begin{array}{c}\text { After } \\
\text { Matthew }\end{array}$ \\
\hline & $2012 / 13$ & $2013 / 14$ & $2014 / 15$ & 2015/16 & $2016 / 17$ & $2016 / 17$ \\
\hline & & (millio & n\$) & & & \\
\hline Total Revenue & 1,355 & 1,451 & 1,701 & 1,889 & 2,169 & 2,157 \\
\hline Current Revenue & 1,354 & 1,450 & 1,698 & 1,889 & 2,167 & 2,155 \\
\hline Tax revenue & 1,216 & 1,246 & 1,500 & 1,698 & 1,968 & 1,959 \\
\hline Non-tax revenue & 139 & 205 & 198 & 191 & 198 & 196 \\
\hline Capital revenue b/ of which: & 0 & 0 & 3 & 0 & 2 & 2 \\
\hline Grants & 0 & 0 & 0 & 0 & 2 & 3 \\
\hline Total expenditure & 1,901 & 1,931 & 2,084 & 2,152 & 2,267 & 2,336 \\
\hline Current expenditure & 1,546 & 1,597 & 1,711 & 1,973 & 2,024 & 2,080 \\
\hline Goods and services & 354 & 308 & 331 & 336 & 359 & 376 \\
\hline Staff costs & 594 & 624 & 640 & 660 & 734 & 741 \\
\hline Transfers & 598 & 664 & 740 & 977 & 932 & 962 \\
\hline Interest on debt & 198 & 212 & 233 & 279 & 272 & 282 \\
\hline Domestic & 142 & 149 & 154 & 179 & 185 & 194 \\
\hline External & 56 & 63 & 79 & 99 & 87 & 88 \\
\hline Others & 400 & 452 & 507 & 698 & 660 & 680 \\
\hline Capital expenditure & 258 & 252 & 280 & 176 & 242 & 257 \\
\hline Net lending & 96 & 82 & 92 & 3 & & 0 \\
\hline Primary balance & -348 & -268 & -149 & 16 & 174 & 103 \\
\hline Overall balance & -546 & -480 & -382 & -263 & -98 & -179 \\
\hline
\end{tabular}

Source: Ministry of Finance, Central Bank of The Bahamas and Assessment Team

The evolution of the fiscal deficit and debt after Matthew will be influenced by government's plan for phased reconstruction period over about three years. This will help to prevent a rapid ballooning of the deficit and public debt. Moreover, the phased plan is being implemented to relieve capacity constraints in skilled construction workers for the rebuilding programme. Nevertheless, it is expected that given the pressure for timely reconstruction, especially of private homes and main arterial roads and bridges, the bulk of the reconstruction will be prioritised for budget cycle 2016/17. 
Figure 14- IPrimary and overall fiscal balances before and after Hurricane Matthew

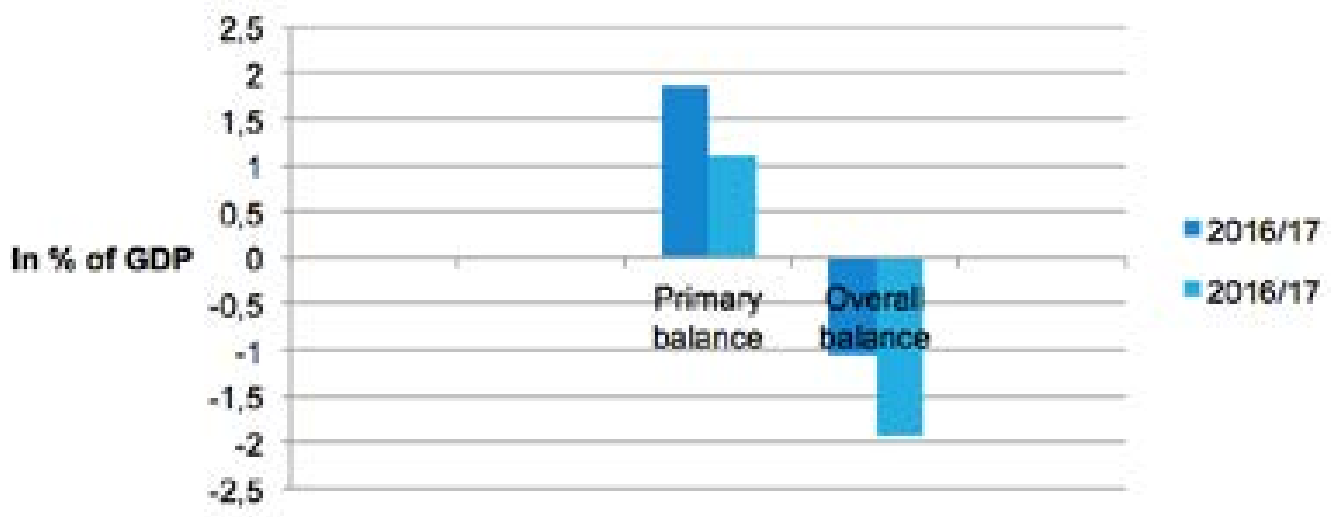

Source: Ministry of Finance, Central Bank of The Bahamas and Assessment Team

As a result, government's initial borrowing of $\$ 150$ million and the expected allocations between the key items-including the capital works programme and transfers and subsidies for relief and reconstructionwill widen the fiscal deficit from an estimated 1.0 per cent of GDP in 2016/17 before Hurricane Matthew to 1.9 per cent of GDP after Matthew. This would represent a $\$ 81$ million increase in the deficit after the hurricane. The hurricane is expected to lead to a modest ( 0.5 per cent) decline in total revenue-mainly reflecting tax exemptions-and to a limited impact on the VAT, reflecting reduced buoyancy with the decline in activity, particularly in tourism and fisheries sectors.

Meanwhile, total expenditure is estimated to increase more than 3 per cent during 2016/17. The increase will stem from higher expenditure on relief and recovery including food, water and building supplies. Expenditure on goods and services is estimated to grow about 5.0 per cent (\$27 million), associated with procurement of construction materials, machinery and equipment to facilitate government's reconstruction programme. A significant portion of government's reconstruction work is expected to be undertaken by the public works division. AS a result, spending on staff costs are expected to increase by 1.0 per cent to $\$ 741$ million after Matthew. Transfers and subsidies are estimated to increase more than 3.0 per cent (\$30 million), reflecting subventions to public utilities and private citizens for relief and reconstruction after the hurricane. Growth in transfers would also be linked to higher interest payments, owing to the contracting of mostly domestic debt to finance the reconstruction. 
Meanwhile, capital expenditure is estimated to increase about 6.0 per cent (\$15 million) from the budgeted amount, reflecting outlays for repairs and reconstruction of roads, bridges and other infrastructure. The pace of capital disbursements on reconstruction would be partly affected by capacity constraints in the supply of skilled labour and the speed of procurement for building materials. This is expected to be particularly so if, as projected, the mega Baha Mar Resort resumes reconstruction during the early part of the reconstruction period after the hurricane.

\section{The Impact of the balance of payments}

The current account deficit is estimated to widen by almost 7.0 per cent in nominal terms from (\$1,026 million) 11.4 per cent of GDP before Matthew to (\$1,095 million) 12.1 per cent of GDP after the hurricane. The trade deficit is estimated to widen by around 1.4 per cent, reflecting growth in imports for the reconstruction, particularly in the hotel, housing and infrastructure sectors. The services surplus is estimated to contract by 2.4 per cent, reflecting a 1.5 per cent decline in travel receipts, owing to the disruption in the tourism sector. The loss of business in tourism was estimated at over $\$ 59$ million, however, given that some hotels will not be fully operational for the remainder of 2016, it is expected that a portion of these losses will carry over into 2017. 



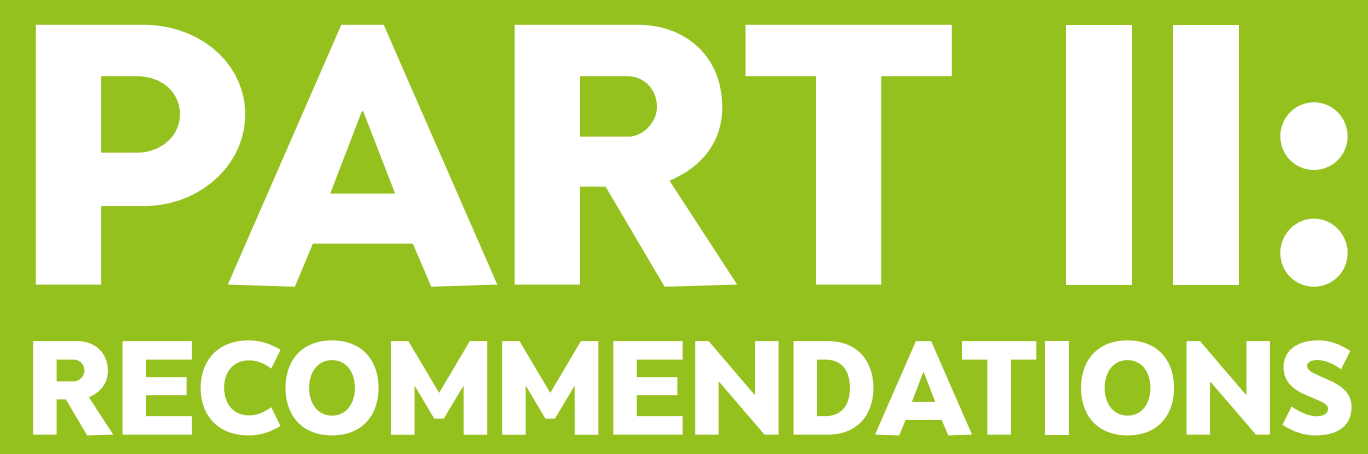





\section{Recommendations for a resilient reconstruction}

A child born in The Bahamas in 2016 will be 84 years old in the year 2100. In that lifespan, she can expect to see, by conservative projections, a rise in sea levels of two to three feet $(60$ to $90 \mathrm{~cm})$ above where they are today. Less conservative projections recognize that there is some risk of a substantially greater rise. This is the start of a very long-term trend in which continually increasing sea levels will affect The Bahamas for hundreds of year to come-potentially not ending until such time as the entire volumes of the Greenland and Antarctic ice sheets have been added to the water in the Earth's oceans.

By the time the rise in sea level reaches three feet $(90 \mathrm{~cm})$, the increase in water level will be enough to lap at the thresholds of houses in some of today's low-lying communities, and it will have already led to profound changes to the coastlines, topography, and bathymetry of the Bahamian archipelago. Natural coastal protections, including mangroves, barrier islands, beaches and reefs, will become eroded or further submerged, leading to increased risk of damage to sea-side infrastructure as a result of storm surge and wave action.

At the same time, the increase in water temperatures because of global warming is likely to contribute to a tendency for tropical cyclones to be, on average, stronger than they have been in the past. Thus, large storms like Hurricanes Matthew and Joaquin can be expected to impact the islands with an increased frequency.

As a result of global warming and sea-level rise, the people of The Bahamas will face tough choices about relocating coastal populations and investing in infrastructure that will create resilience to the increased disaster risk and ongoing climate change. The damage wrought by Hurricane Matthew's storm surge to communities such as West End on Grand Bahama and Lowe Sound on Andros, or by Hurricane Joaquin to Lovely Bay on Acklins and Landrail Point on Crooked Island should stand as a warning that the era of these tough choices has already arrived.

This is the context for our recommendations (Table 59) for a resilient reconstruction in the wake of Hurricane Matthew. The recommendations are organised under the five pillars of action proposed by the Global Facility for Disaster Reduction and Recovery (GFDRR). The five pillars form the guiding principles of the Sendai Framework for Disaster Risk Reduction. 
Table 59- Pillars for disaster risk reduction

\begin{tabular}{|l|l|l|}
\hline Pillar 1 & Risk identification & $\begin{array}{l}\text { Improved identification and understanding of disaster risks through building } \\
\text { capacity for assessments and analysis. }\end{array}$ \\
\hline Pillar 2 & Risk reduction & $\begin{array}{c}\text { Avoided creation of new risks and reduced risks in society through greater } \\
\text { disaster risk consideration in policy and investment. }\end{array}$ \\
\hline Pillar 3 & Preparedness & $\begin{array}{l}\text { Improved capacity to manage crises through developing forecasting and disaster } \\
\text { management capacities. }\end{array}$ \\
\hline Pillar 4 & Financial protection & $\begin{array}{c}\text { Increased financial resilience of governments, private sector and households } \\
\text { through financial protection strategies. }\end{array}$ \\
\hline Pillar 5 & Resilient recovery & Quicker, more resilient recovery through support for reconstruction planning. \\
\hline
\end{tabular}

Source: Global Facility for Disaster Risk Reduction (GFDRR),

"Strategy 2013-2015. Managing Disaster Risks for a Resilient Future."

\section{Pillar 1: Risk identification}

Pillar 1 entails development of a broadly understood societal recognition of disaster risks and development of specialised institutional knowledge concerning the hazards, exposure and vulnerabilities of every community. The most significant natural hazards to The Bahamas are tropical cyclones. These are extreme, widespread events that can be expected continue to cause major losses in the future. Other risks include lightning, tornadoes, tsunami and drought as well as man-made risks such as oil spills or other environmental degradation.

The process of risk identification focuses on two aspects. First, it considers the assessment of multiple hazards including their frequency, intensity and magnitude. Second, it identifies exposed infrastructure, services, communities and other elements, as well as their vulnerabilities. Identifying the risks makes it possible for a country to foresee potential effects and impacts of a disaster on its society and economy. Implementations of programmes for mapping, modelling and cross-institutional data sharing are needed to contribute to this process. Further, there is a need for an effective mechanism to ensure that the outputs of such activities are incorporated into the construction of national and local development plans.

Prosperity in The Bahamas is reliant on its touristic appeal, which in turn revolves around its beautiful beaches, flats, coral reefs and marine life. Because tourism infrastructure is mainly close to the sea, it is at higher risk of inundation by storm surge and sea-level rise, especially in areas not defended by mangroves, reefs and other natural infrastructure. The same is true of another economic engine in the country - the fishing industry. The livelihoods of fisher-folk rely on an intact marine environment, and sea-side fishing communities are among the most vulnerable when waters rise-whether the rise occurs in minutes, or over the course of decades. Thus, the resilience of the environment is foundational to the resilience of the country as a whole. 
In consideration of the environment, many studies have been conducted in The Bahamas around sea level rise, climate change, species migration, and on critical sub-tropical marine habitat types. These studies-by academic institutions, NGOs, and in conjunction with financial institutions and the government of Bahamas-have provided many recommendations for sustainable adaptation to environmental changes for the Bahamian people. Many adaptation options require changing laws, different investment strategies, and a commitment to the protection and restoration of resources that keep much of the Bahamian economy running.

One important example of these kinds of studies is the Natural Capital (NatCap) project on Andros. Stanford University conducts the NatCap project, funded partly by the Inter-American Development Bank. The project analyses the value of environment services to the people of Andros and considers how natural and human ecosystems will respond to climate change in combination with different types of economic development.

One output of the project is a Coastal Vulnerability Index (CVI). This model uses factors such as wave height and bathymetric and coastal profiles to forecast relative exposure to risk of areas along the shoreline. The model is a tool for understanding what areas are at elevated risk. These areas can be further evaluated to determine if their infrastructure and population is unduly vulnerable. Figure 15 illustrates the CVI in populated areas of Andros. Expanded use of this tool would help identify communities in The Bahamas in need of relocation or additional coastal protection.

Figure 15- Coastal vulnerability index (CVI) in North Andros

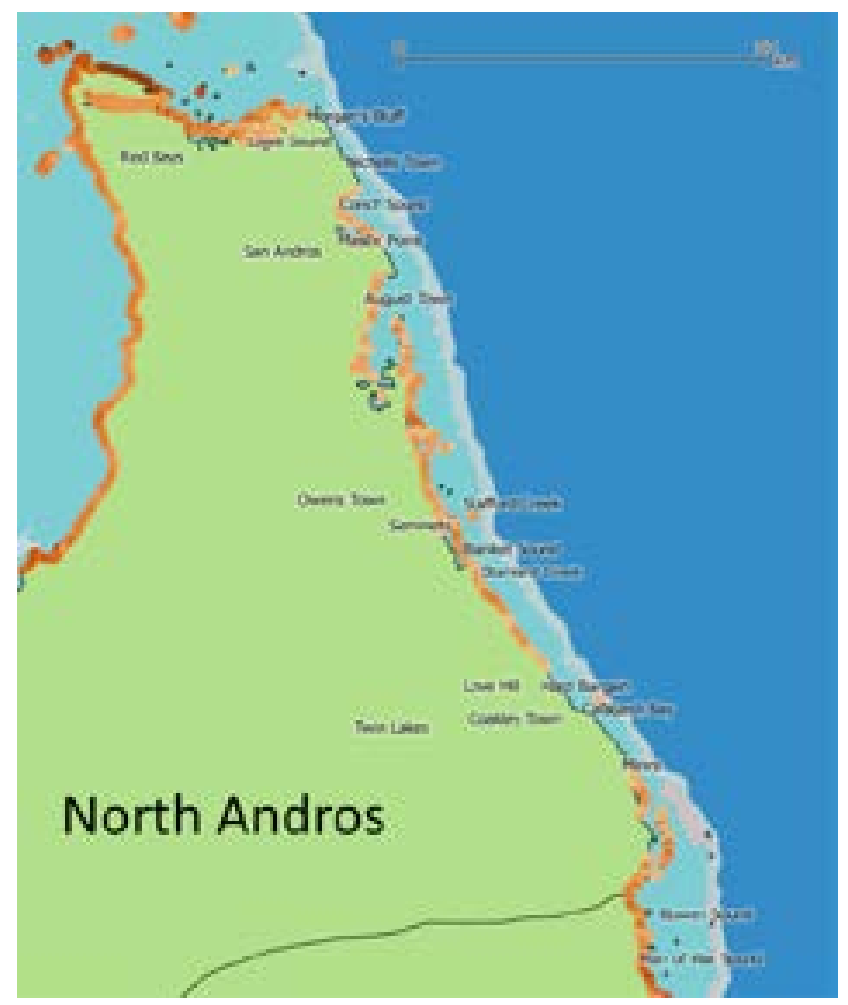

Source: Natural Capital Project 
The CVI tool cannot be considered in isolation. For example, while the model indicates that the north shore of Andros is particularly at risk, it labels portions of the town of Lowe Sound as in relatively sheltered points along the shoreline. However, Lowe Sound is where Hurricane Matthew caused the greatest damage to Andros buildings and infrastructure. This kind of model could not account for the particular disposition of this specific hurricane, and thus the way in which the angle of wind interacted with the contours of the coastline. Apparently, as the direction of the wind changed, water that had been driven to pile up at one end of the sound quickly shifted to a different location. This water appears to have interacted with the contours of the shallow coastal waters in a way that magnified the height of the water as it encroached upon the town.

A similar situation was seen on Crooked Island during Hurricane Joaquin. There, a seemingly sheltered area-the location of the Landrail Point Power Station-was in fact inundated by storm surge that had been exacerbated by a topographical funnelling effect. It may be more difficult to determine what areas are at this type of risk, because so much is dependent on characteristics of a particular storm. For making this kind of determination, however, a SLOSH model may be a useful tool. SLOSH stands for "Operational Storm Surge Basis for the Sea, Lake, and Overland Surges from Hurricanes."

A SLOSH model analyses how various hurricane conditions would affect a particular coastline. Runs of a SLOSH model-built around probabilistically simulated hurricane paths-could be used to find specific locations at risk for this type of surge event. However, SLOSH models require high quality data on basins and coastlines. Therefore, it is not currently possible to run this analysis against all parts of The Bahamas. Neither Andros nor Grand Bahama currently has model support in the SLOSH programme.

Figure 16 shows areas of The Bahamas with SLOSH-model coverage. Expanding SLOSH coverage to other islands in collaboration with the United States National Hurricane Centre would be a worthwhile undertaking. 
Figure 16- Map detail from the U.S. National Hurricane Centre's "Operational Storm Surge Basis for the Sea, Lake, and Overland Surges from Hurricanes (SLOSH) Model."

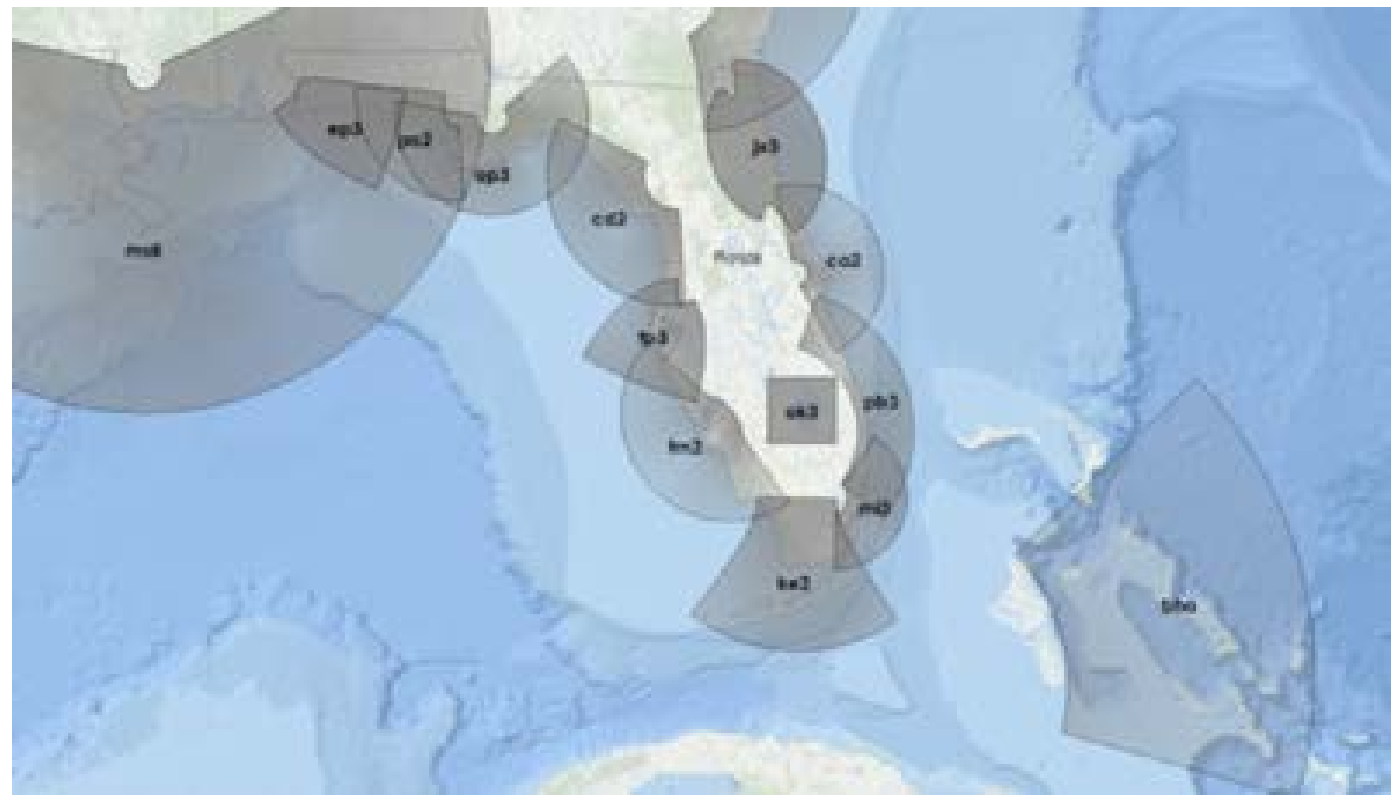

Source: United States National Hurricane Centre

Coordinating and understanding research on risk identification and modelling in The Bahamas should be considered a disaster risk management function, and thus would seem appropriately to reside with the National Emergency Management Agency (NEMA). However, it must be determined whether NEMA has the institutional capacity to perform this function, or whether research on risk identification should be the remit of a separate institution-perhaps in academia-that can focus on this task without the frequent disruption caused by the need to organize disaster response activities.

\section{Pillar 2: Risk reduction}

The pillar of risk reduction considers how policy and investment programmes can be targeted to reduce disaster risk. It is the process through which responses to the risks identified in Pillar 1 are made through adjustments to national laws, local ordinances and instruments for longterm planning. The most salient of these issues concerns the need for a national conversation on how best to manage the removal of infrastructure and population from the highest-risk areas along coastlines, and the hardening against risk of locations that are to remain populated. This should be considered from an institutional, engineering and human rights perspective. 


\section{Human rights}

The human rights perspective may be the most difficult area to navigate concerning long-term risk reduction. Populations are understandably resistant to the relocation of communities, which can have profound effects on the lives and livelihoods of the people who live there. Actions should not be taken without the due participation and consent of persons in affected communities.

The Peninsula Principles on Climate Displacement within States (2013) is a set of human rights guidelines for fair and equitable management of decision-making processes concerning movement of populations because of ongoing climate change and the associated elevation of disaster risk. Principle 6 says that States should "provide adaptation assistance, protection and other measures to ensure that individuals, households and communities can remain in their lands or places of habitual residence for as long as possible in a manner fully consistent with their rights." Principal 10 says that States should "ensure that no relocation shall take place unless individuals, households and communities (both displaced and host) provide full and informed consent for such relocation." Principal 10 also says that relocation can be required to take place without such consent only in "exceptional circumstances when necessary to protect public health and safety or when individuals, households and communities face imminent loss of life or limb."

Respect for human rights mandates that endangered communities cannot simply be removed by fiat of the authorities, but that a long-term process of consultation, planning, consent-building, and incentivisation is necessary. That said, continued and extensive public investment to rebuild destroyed housing and infrastructure in areas at high risk is also not an appropriate response. Rebuilding in high-risk areas should be limited to that which is necessary to maintain public safety and the basic services to which residents are entitled. However, broad economic redevelopment should focus on sustainably sited communities, and this can serve as an incentive to draw populations in at-risk areas to resettle on safer ground.

For example, the government is advised to create a fast-track program and incentives for citizens who live on or near coastlines to relocate to Crown Land. However, simply opening up new building sites is not in itself sufficient to draw populations away from at-risk areas. This has been demonstrated in the past when the government opened up a new settlement area to entice relocation of citizens from Lowe Sound. Ultimately, relatively few people moved to the new location, in part because it was not near the centre of economic activity. Perhaps more will move now, following the devastation wrought on the town by Hurricane Matthew, 
but there is a need for additional urban planning and economic development to make relocation a more inviting prospect to those remaining in harm's way. One way to make resettlement areas more appealing is to establish public facilities for community interaction, such as libraries, parks and recreation centres, at the heart of developable areas that provide both commercial and residential opportunities.

\section{Improving the built environment}

Quality standards for siting and construction have important implications for the resilience of housing and infrastructure. An example can be found on Grand Bahama. There, the community of West End was devastated by wind and storm surge, but a high-end tourist facility not far down the road weathered the storm with a relatively limited damage. Buildings in the tourist facility were built to a high standard of construction, with appropriate setbacks from the water and with shoreline protection afforded by beaches and vegetation. Buildings in West End commonly had construction deficiencies that contributed to the loss of roofs. Many of these buildings were located directly across the street from the ocean with the protection of only a low sea wall.

The most effective way to mitigate losses of life, property and function is to ensure that buildings are designed to be disaster resistant. Buildings should not be constructed with wooden external walls. All exterior elements such as water tanks, pumps, generators, gas bottles and air conditioning units should be sufficiently affixed and protected. This approach should be incorporated into project planning and design at the earliest possible stage of the development process. Building design and material decisions should be based on an integrated "whole building" approach.

\section{Some mitigation measures include (Florida Foundation):}

1. Water barriers such as a sealed roof deck could prevent significant water intrusion if pieces of the roof are blown away. This roof deck also provides additional insulation to make dwellings more energy efficient.

2. Anchoring roof-to-wall: reinforced foundation-to-wall, floor-tofloor and wall-to-roof connections establish a continuous load path. This enables the dwelling to resist high-wind forces as a unit. Damage usually occurs in the weak links in a load path.

3. Gables taller than 4 feet $(1.2 \mathrm{~m})$ would benefit from reinforcing the framing and bracing the top and bottom. Gables should be designed for specific locations and types of homes. 
4. Flood vents relieve hydrostatic pressure from foundation walls and other enclosures by allowing flood water and debris to flow through the space. Common air vents impede the flow of flood water and trap debris. When floodwater is not able to flow through the opening, pressure builds up and can compromise the structural integrity of the house.

In areas that are at risk and are where relocation is unlikely in the short term, zoning and land-use planning should seek to minimize exposed infrastructure and population. For example, minimum setbacks from the ocean should be observed, and flood zoneregulations should require the elevation of structures in areas close to the seashore.

Elevation should also be considered for roads. If built above flood level, the road may serve as a secondary protection barrier against storm surge. Roads also require inclusion of drain channels to conduct rainfall to properly designated flooding areas as determined by an adequate general master plan.

New systems of low-cost housing should be evaluated for adoption into the country's building practices. There are types of construction materials and techniques well suited for locations subject to frequent flooding. For example, multipoint foundation systems-consisting of an engineered steel or aluminium rigid platform-sit on the top of the soil itself and keep the building level and straight regardless of soil heaving and settling (Figure 17). Unlike piles or screw jacks, which can move and shift over time and cause structural damage, these foundation systems prevent damage to the integrity of the building and do not require maintenance. Foundations can be built at heights ranging from 2' to 8', allowing the building to remain above projected flood waters.

\section{Some characteristics of multipoint foundation systems include:}

- $\quad$ Cost competitive with alternative foundations

- $\quad$ Typical assembly with hand tools in a few days

- $\quad$ No need for excavation, piers, piles, concrete

- $\quad$ Pre-engineered for each building plan

- Durable galvanized steel and aluminium

- $\quad$ Securely anchored against wind forces

- $\quad$ Uniformly supports and stiffens the building

- $\quad$ Easily modified for future additions

- $\quad$ Used in both new and retrofit applications

- Minimal site preparation and can be placed on native soil

- $\quad$ Gravel pad and timber pads not required in most circumstances 
Figure 17- Multipoint foundations
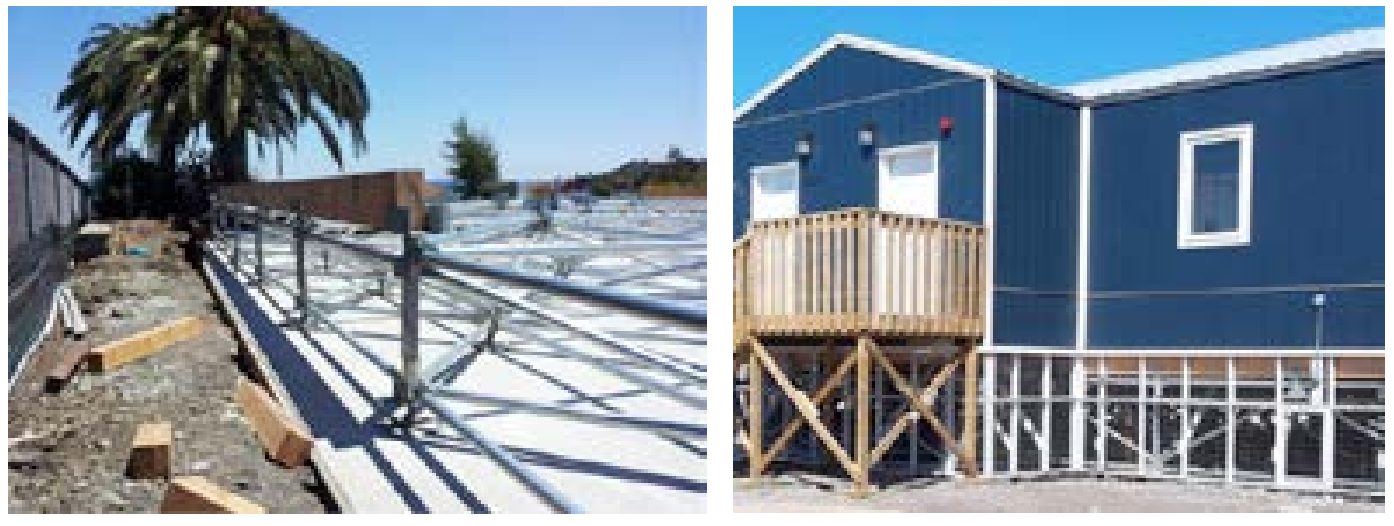

Source: Multipoint-foundations.com

There is a need for overall improvement in building materials. Building practices frequently entail the use of beach sand, sea shells and other locally sourced components. However, these materials may be structurally unsuitable for building purposes unless a proper structural and civil engineer is contracted to design and supervise the work. If these materials are used, they have to be applied in a specific manner to comply with proper engineering criteria so that the structures have an adequate behaviour when submitted to static and dynamic loads. In cases where locally sourced materials are to be used, it is firmly recommend that approval of a civil engineer be required for a project to proceed.

Maintenance also affects structural integrity of buildings. For example, in the Berry Islands, the airport presents numerous deficiencies, as the current administration offices are in a very deteriorated building. Most of the damage from the hurricane was due to lack of proper building maintenance. This building should be replaced with one having a resilient structural design. However, if it had been properly maintained, the building would have fared better in the storm, and the expense of replacement would not have become necessary. Unfortunately, lack of maintenance appears to be a chronic problem with many public buildings in The Bahamas.

\section{Strengthening institutions for standards and compliance}

The audit and supervision tasks of the Ministry of Works (MOW) should be strengthened, especially in the Family Islands. These roles should also be expanded for the Grand Bahama Port Authority (GBPA) in Grand Bahama. These entities must be empowered to guarantee that design and construction processes are in compliance with basic standards established to ensure the integrity of every structure. 
Supervisory capabilities of these organizations should be improved through actions such as:

1. Determining the required number of inspectors responsible for onsite supervision and establishing a plan to reach the required target. Even if a building code is adopted, it is crucial that MOW and GBPA have the resources to supervise all stages of the process.

2. Designing the technical, academic and professional profile of inspectors to ensure that the human resources of MOW and GBPA have the necessary skills and knowledge to carry out supervision and inspections.

3. Establishing responsibilities for public and private designers, contractors, developers and any other relevant stakeholders to ensure compliance with standards and rules throughout the construction process. Sanctions should be established to deter violation of construction standards.

4. Creating an official document authorized by the Executive Director of the Association of Engineers and Architects, in which building professionals and specialists and other persons authorized in accordance with regulation shall leave written record of their performance.

\section{Pillar 3: Preparedness}

The preparation pillar entails establishment of institutional mechanisms and infrastructural capacity to enable effective response to a disaster. These must be flexible enough to perform well under a number of different disaster scenarios, as identified under Pillar 1. For example, in the case of Hurricane Matthew, there was an extended lead time to the approach of the storm. This enabled timely preparation and delivery of warnings to the public. As a result, people had time to board up windows and doors and, in high risk areas, to take refuge in hurricane shelters. By contrast, in Hurricane Joaquin, the storm consolidated on short notice and took an unexpected track; it affected islands on which people were not aware of oncoming danger. There was little public warning, and many storm shelters went unused.

\section{Public early warning systems}

One important recommendation in the IDB-ECLAC report on Hurricane Joaquin was for establishment of a cellular-phone based warning system. The need for improvements to early warnings was noted by, among others, the telecommunications regulator-the Utilities Regulation and Competition Authority (URCA). URCA established a project in is 2016 annual plan on use of information and communications technologies (ICT) for disaster preparedness and management (URCA 2016). This increased 
attention may have had dividends; NEMA and Bahamas Telecommunications Company (BTC) did work to send text messages to all BTC subscribers throughout the islands before the arrival of Hurricane Matthew..

While the use of cellular-phone based warning messages in Matthew marks an important demonstration of the country's improvement in early warning capacity since Joaquin, some outstanding concerns exist for the current system. First, to avoid congesting the cellular network by sending messages to all of the more than 260,000 BTC subscribers at the same time, messages must be sent in a throttled manner. This means it takes about six hours to send warning messages to all subscribers. This is adequate for an event with a long lead time, such as Hurricane Matthew. But it would not be effective for a faster-onset event such as a tornado, tsunami, or a hurricane such as Joaquin, which changed course rapidly.

Congestion associated with the mass-delivery of text-message warnings also had an impact after the storm. The SMS-based public information system was used in the hours and days after the hurricane to inform the public about, for example, the need to boil water prior to consumption, or about the locations where relief supplies were available. However, in at least one case, BTC had to deny NEMA's request for issuance of a public information message because the network was already running close to capacity due to the elevated level of cellular communications among the public in the immediate post-disaster environment. It would not have been possible at that time to send out a mass text without disrupting the network.

Technologies exist to alleviate the congestion problem in emergency public information messages. These include cell broadcasting, "new SMS" systems, and LTE or app-based systems. Each of these technologies has advantages and disadvantages. There is a need to evaluate them to determine which would be best suited for public warning systems in The Bahamas. In early 2017, ECLAC will publish a study discussing some of these technologies, entitled Strengthening cooperation between telecommunications operators and national disaster offices in Caribbean countries. This document will also provide broad guidance on ways that organisations such as NEMA, BTC, NewCo and URCA can work together to improve coordination on disaster planning and response efforts. This document can help guide establishment of a national plan on disaster and telecommunications to incorporate deployment of technology to support an effective public warning and information system.

\section{Public evacuations and sheltering}

The public evacuation and sheltering process was far more effective during Hurricane Matthew than during Hurricane Joaquin, due in large part to the longer advance warning. However, there is a need to take stock of the Hurricane Matthew experience to update protocols for evacuation and sheltering on each island. The list of buildings designated as temporary shelters should be reviewed to ensure that they are both 
appropriately sited and structurally sound. During Hurricane Joaquin, one designated shelter in a church on Acklins wound up being flooded by storm surge; it was fortunate that no one had taken shelter there. $A$ comprehensive review of sheltering protocols can help ensure that this kind of situation could not occur in the future. There is also a need for annual exercises throughout the country to ensure that such protocols are disseminated and practiced.

Information collection and management are important elements of evacuation and sheltering protocols. They are important gateways through which the population affected by a hurricane will have their needs registered with the government. Creating a roster of affected persons enables relief to be directed to them and policy interventions to be implemented to meet their needs. Thus, the protocol for sheltering should ensure that information is collected for each family when they check into a hostel. This includes the number of family members; the age, sex and disability status of each person; and the address of the family residence. This list should be used after the disaster to follow-up with those who have been most affected to ensure they have access to relief aid and social services. Further, if people know that a shelter serves as a gateway for access to rebuilding assistance, those in endangered areas will be more likely to use the shelter instead of riding out the storm in a risky location.

There is also a need to ensure that public shelters are equipped with emergency power supplies and communications equipment. When the disaster assessment team visited the Berry Islands, a concern was expressed that shelters had no power or communications after the storm, as the electricity grid and cellular towers had been damaged. Each emergency shelter should be equipped with a generator and either a satellite telephone or UHF radio.

\section{Decentralizing response efforts}

Several officials in affected islands expressed concerns about the highly centralized nature of the disaster response, with local efforts hampered by the need to wait for NEMA or other officials in Nassau to direct the distribution of supplies and use of relief funds. In Grand Bahama, there was a concern that relief supplies were directed through the airport in Nassau instead of directly to Freeport. This created delays and additional complication in the effort to provide relief to the affected population.

In Andros, local officials said they experienced delays accessing and directing relief funds, due to the need to seek prior approval from Nassau. For example, there was a need to hire local people to retrieve coffins and corpses that had been scattered when a cemetery was impacted by storm-surge, but local officials did not have immediate access to funds to do so. In another example, a school administrator used her personal funds to establish a bank account to finance expenses relating to relocation of a school that had been heavily damaged. It was anticipated that 
funding for these activities would eventually be provided by the government, but there was a need to cover expenses incurred before such funding became available. Officials in Andros recommended the establishment of a mechanism to ensure that district governments have early access to funds that they are able to control in an immediate post-disaster situation.

There is also a challenge related to information management in the post-disaster situation. Currently, all information flows through NEMA, and is not distributed to stakeholders in a timely manner. For example, after Hurricane Joaquin, NEMA was not able to provide the disaster assessment team with copies of data sets on damage that had been submitted to them by a private organization. After Hurricane Matthew, it was unclear what information was available through NEMA, and some reports that government organizations had provided to NEMA were never retransmitted to the assessment team. Moreover, NEMA does not operate a public website through which it shares information cleared for public release. This is problematic from both operational and a transparency perspectives. NEMA operates a Facebook page through which some communications are provided to the public. However, that does not provide the effective, searchable gateway for specific information needed to support disaster response and planning for future disasters.

\section{Pillar 4: Financial protection}

Areas damaged by Hurricane Matthew had higher rates of insurance coverage than those damaged by Hurricane Joaquin. However, in many cases, even if a building was covered by insurance, deductibles were so high that policies did not pay off, causing homeowners and institutions to absorb all of the financial shock associated with repairs. In general, insurance in the country has two problems: low insurance penetration and underinsurance.

One measure to help relieve this problem would be the elimination of the value added tax (VAT) on insurance policies. Insurance rates in The Bahamas are the highest of the Caribbean countries; a typical policy has an annual cost of 1 per cent of covered value, with a 2 per cent deductible. To encourage acquisition of insurance by the private sector, the government could consider eliminating the VAT on insurance.

The purchase of insurance for public sector infrastructure should be further studied. The Bahamas is a country very exposed to natural hazards and the resulting disasters have significant effects on public infrastructure. Financial protection should be established starting with new public works. For this, it is important to conduct negotiations with private insurance companies to include costs that the government would incur when buying this service. This policy is followed in other countries, such as Ecuador, where the purchase of insurance for public infrastructure is mandatory. 
One area not covered by insurance-because risk is so high it is considered "uninsurable"-are overhead networks for power distribution and wire-based telecommunications. Repairs to these represent significant costs to telecommunications companies, and particularly to the power companies that own the infrastructure. Lack of insurance on this infrastructure also means a lack of pressure from insurance inspectors that would help assure high standards of maintenance, particularly in tree trimming and in replacing old or obsolete poles.

During Hurricane Matthew, less-than-optimal maintenance standards contributed to much of the service failure of this infrastructure. Broader cost sharing between pole owners (electricity utilities) and pole tenants (telecommunications companies) would help to fund better utility pole and right-of-way maintenance, thus reducing overall risk not only to these parties but also to those who rely on them. The utilities regulator should consider whether it would be appropriate for telecommunications operators to be charged for their tenancy on a per-attachment per-pole basis, rather than on a per-operator per pole basis. There is also a need to review charges paid by the government for public-sector uses of this infrastructure.

Another policy for financial protection of the power sector is the establishment of a "Hurricane Fund," which has been created in other countries such as Belize. Such a fund would be established under supervision of the regulator, and paid for through a surcharge on electricity bills. Payments into this fund would continue until such time as the fund reaches a certain threshold - say $\$ 15$ million - at which time the funds would be set aside to gain interest through managed investments. In the event of disaster that will require a costly expenditure for recovery, power utilities could petition the regulator for release of these funds to defray their expenses. In effect, this would provide power companies with an insurance policy against damage to the distribution infrastructure, with coverage financed by the utility's own customers.

Finally, in 2016 the government of The Bahamas declined to renew its insurance policy with the Caribbean Catastrophe Risk Insurance Facility (CCRIF), opting instead to use the premiums to establish its own disaster fund. This decision was taken after there was no pay-out from CCRIF to The Bahamas after Hurricane Joaquin in 2015. A representative of the government has indicated the decision was made to discontinue coverage because it was considered "virtually impossible to ever get a claim; the threshold was just too high. (McKenzie 2016)." It is unknown whether the damage from Hurricane Matthew would have been sufficient to trigger an insurance policy pay-out from CCRIF had the policy been in place, though payments were made as a result of the hurricane to Barbados, Haiti, Saint Lucia and Saint Vincent and the Grenadines. 


\section{Pillar 5: Resilient recovery}

As the country rebuilds from Hurricane Matthew, individuals and institutions need to consider what they can do to assure economic recovery in the short-term while building a framework for long-term resilience against future disaster events and the effects of global climate change.

\section{Ensuring macroeconomic stability}

The challenging macroeconomic situation, marked by flat or negative growth and burgeoning public debt, will complicate recovery and reconstruction after Hurricane Matthew. Further, Matthew arrived while the rebuilding after Hurricane Joaquin yet continued. Nevertheless, to return the economy to a reasonable state of normalcy both to nurture growth and to prevent undue hardship to affected households, especially the poor, the following measures are proposed to galvanise the recovery and reconstruction effort.

The national rehabilitation programme should give priority to the speedy recovery of the productive sectors, especially tourism and fisheries in the affected islands. The major focus should be on limiting loss of business for hotels and other tourist-related businesses during the current peak winter season. To the extent that tourist operators can get their properties up and running for a significant part of the high season, this would reduce the impact on their profit margins, limit the fall in tax receipts from the sector and mitigate the overall impact of the hurricane on the economy.

It is expected that the large, adequately insured hotels, especially in Grand Bahama, would be able to use insurance receipts, internal funds and loans to restart operations in a relatively short period of time. However, smaller properties that were uninsured or underinsured might require some government assistance to expedite their recovery and enable them to benefit from the winter season. Assistance could be provided under the duty-free concessions programme implemented after the hurricane. Small-scale fisher-folk and small farmers, who tend to be uninsured, would require assistance by the state to recover their livelihoods. This could be done through a well-targeted cash grant programme and duty concessions for the purchase of lost motors and other fishing equipment.

This is the second year in a row that The Bahamas has been impacted by a hurricane. It therefore provides a clear warning of the need for resilient recovery and reconstruction in the aftermath of these disasters. The impulsive reaction, particularly of residents whose homes have lost their roofs, is to build back as quickly as possible, often with self-help and with little regard for building codes. Nevertheless, this impulse should be resisted, and the state should intervene where necessary-particular- 
ly where it is providing financial assistance in the home rebuilding programmes-to ensure that repairs are done in accordance with building codes and with a reasonable degree of mitigation to reduce vulnerability to future hurricanes.

The government of The Bahamas has undertaken to borrow $\$ 150$ million to facilitate reconstruction and recovery. However, to contain growth in public debt, the government should also explore public-private partnerships-for example, in the rehabilitation of infrastructure-to contain the growth in public debt. Inclusion of the private sector could bring managerial and technical expertise that could facilitate the on-time, within cost and high quality delivery of reconstruction projects.

Zhang and Kumaraswamy (2015) highlight the need for 4P systems, that is, public-private-people partnerships. These systems can deliver resilient reconstruction by leveraging the leadership and coordinating role of the public sector; the professionalism, innovation and efficiencies of the private sector; and the on-the-ground, embedded knowledge and experience of NGOs and community-based organisations. In the Matthew-affected islands of The Bahamas, 4P systems could deliver reconstruction with proper coastal setbacks, policy barring location of burial sites too close to the coast, and established standards and guidelines for retrofitting damaged homes and other properties.

Fiscal sustainability is critical for generating savings to facilitate reconstruction after natural disasters. Nevertheless, fiscal policy in The Bahamas is pro-cyclical. This leads to over-spending during boom times and forced expenditure cuts during recessions. Government should implement measures to reduce pro-cyclicality by establishing clear targets for growth in spending, especially the contingent liabilities of public corporations. This, combined with reform of the budgeting framework, could lead to a fiscal rule that enables the government to increase savings during boom times. That approach not only would facilitate recovery and reconstruction after natural disasters but also would limit growth in public debt after these events.

\section{Building sustainable infrastructure}

In a broad sense, there is a need to ensure that human activity in The Bahamas works in harmony with the elements of the natural ecosystem, so that economic development takes advantage of the support offered by environmental services instead of becoming a hazard to them. For example, sustainable forestry programmes that utilize prescribed burning and selective timber harvesting can generate revenue while reducing wildfire threats and maintaining biodiversity. Thus, nature and humankind can work together for mutual benefit.

Similarly, the Bahamian government should consider including green infrastructure in its approach to buffering wave energy, protecting shorelines and implementing other coastal defence measures. Green infra- 
structure along with hardened "grey" solutions can help reduce capital costs, limit maintenance costs, lessen negative biological impacts of grey infrastructure, and improve water quality, aesthetics, biodiversity and the fishing catch.

Seawalls and bulkheads are examples of grey infrastructure used for hundreds of years to protect shorelines, roads, homes and other critical infrastructure. In many cases, grey infrastructure is necessary to protect shorelines in areas with high wave energy. Softer solutions, such as living shorelines, low-crested breakwaters, vegetative buffers, sand nourishment and near-shore reefs have been shown to have exceptional abilities to prevent or reduce shoreline erosion while also improving the ecology of an area.

While seawalls and bulkheads can be effective protection for shorelines, they work by reflecting wave energy back into the sea and downward to the sea floor. This causes shallow-water habitat to erode and deepen, which has many damaging effects, including the following:

- $\quad$ Less sunlight reaches the water bottom, causing seagrasses to die.

- Reflective wave energy causes sediment to remain in suspension, which in-turn reduces the amount of light that can penetrate the water column.

- Many commercial and recreational fish species utilize shallow water fisheries habitat for foraging, mating and laying eggs. Downward reflection of wave energy caused by seawalls deepens this habitat, making it unusable by important fish and shellfish species.

- $\quad$ Some of the most biologically diverse habitat zones are natural shorelines-where the water meets the land. Seawalls cut off these edges, making them much less productive and diverse.

- $\quad$ Seawalls require continued maintenance as a result of being overtopped by waves that erode the land behind them. In addition, reflective properties of a seawall cause erosion at its toe, which can cause it fall into the water.

- $\quad$ Side-to-side erosion caused by seawalls can also cause a domino effect in adjacent properties. When one seawall is installed, it causes erosion on the property next to it. This, in-turn, causes that property owner to install a seawall, and the next adjacent owner to do the same.

One example is in Mobile Bay, Alabama, where almost 40 per cent of the bay's perimeter is hardened by bulkheads and seawalls (Jones, et al., 2012). Most of the bay's earlier densities of seagrass and oysters have disappeared in the last 40 years because of the spread of seawalls and bulkheads, as well as other factors such as pollution and over-fishing (NOAA 2015). 
In many cases, seawalls can be the best choice for coastal protections; however, where opportunities exist, utilizing a green or natural approach can reduce costs, improve biodiversity, abate erosion and significantly reduce maintenance costs. In areas of high wave energy, a hybrid approach using seawalls along with a mangrove forest or artificial reef could extend the life of a seawall while providing critical habitat for lobsters and protecting the shoreline.

In waters south of New Providence, for example, reef balls were used in coral reefs to replace lost hard-bottom that is necessary for survival and proliferation of corals. The Reef Ball Foundation and their certified contractors have carried out shoreline protection projects in lieu of seawalls in the Caribbean and the United States. Reef balls come in multiple sizes. Some have been used in planting mangroves along shorelines as a way to ensure the trees' stability in a higher wave energy climate. Reef balls have also been used as low-crested submerged breakwaters. Installed approximately 100 feet $(30 \mathrm{~m})$ from the shoreline, they dampen wave energy before it reaches the shoreline. Each shoreline is different, and comes with different requirements for wave abatement, but engineering firms around the world are increasing the use of softer, greener approaches to protecting infrastructure. (NOAA 2015) 


\section{Conclusion}

Hurricane Matthew was an expensive event of a kind that may well be repeated with alarming frequency as the climate gets hotter and weather systems more extreme. The Bahamian government faces the difficult task of enabling social and economic recovery in the communities hit hardest by Hurricane Matthew and in the country as a whole. There is further challenge of long-term adaptation to sea level rise for both its infrastructure and its people. Ultimately, the country's resilience is bound tightly to that of its natural environment.

After two Category Four hurricanes in two years, now is an appropriate time for The Bahamas as a nation to reflect on the vulnerability of its position and engage in strategic planning to determine how it intends to prosper in the face of growing hazards. The Inter-American Development Bank and the United Nations Economic Commission for Latin America and the Caribbean stand ready to assist the people of The Bahamas in their pursuit of this objective. 


\section{References}

Anderson, Lakeshia. 2016. Hurricane Matthew damage report. Bahamas National Trust. Nassau, Bahamas.

Cavella, Nico. 30 January 2015. "Government gives \$10m to clearing up oil spills off Clifton." In Tribune 242.

www.tribune242.com/news/2015/jan/30/government-gives-10m-clearing-oil-spills-clifton/

Clerveaux, Virginia. 2016. Rapid needs assessment report North Andros Island, Bahamas. Rep. Caribbean Disaster Emergency Management Agency. N.p.:CDEMA, 2016.

Cohen, Mark A. 2010. A taxonomy of oil spill costs: What are the likely costs of the Deepwater Horizon spill? Rep. Resources for the Future. Washington, D.C.

www.rff.org/files/sharepoint/Worklmages/Download/RFF-BCK-Cohen-DHCosts_update.pdf

Commonwealth of The Bahamas, Ministry of Finance, Department of Statistics. February 2014. "Disability report." 2nd release.

Commonwealth of The Bahamas. 2015. State of the nation report. 79 pp. Part of Vision 2040. National Development Plan.

www.vision2040bahamas.org/media/uploads/State_of_the_Nation_Summary_Report.pdf

Commonwealth of The Bahamas, Ministry of Finance, Department of Statistics. March 2015

"Bahamas population projections."

Displacement Solutions. 2013. The peninsula principles on climate displacement within states. $32 \mathrm{pp}$,

displacementsolutions.org/wp-content/uploads/2014/12/Peninsula-Principles.pdf

Economic Commission for Latin America and the Caribbean. 2014. Handbook for disaster assessment. Ed. 3. Santiago, Chile. 298 pp.

www.cepal.org/en/publications/handbook-disaster-assessment

Economic Commission for Latin America and the Caribbean. In press. Strengthening cooperation between telecommunications operators and national disaster offices in Caribbean countries.

Global Facility for Disaster Risk Reduction. 2012. Managing disaster risks for a resilient future: A strategy for the Global Facility for Disaster Reduction and Recovery 2013-2015. 101 pp. https://www.gfdrr.org/sites/default/files/publication/GFDRR_Work_Plan_2016-18.pdf

Hargreaves-Allen, Venetia. 2010. An economic valuation of the natural resources of Andros Islands, Bahamas. Rep. N.p.: Conservation Strategy Fund. 4 pp.

Hargreaves-Allen, Venetia, and L. Pendleton. 2010. Economic valuation of protected areas in The Bahamas. Rep. N.p.: Conservation Strategy Fund, 2010. Print.

Jelesnianski, C. P., J. Chen, and W. A. Shaffer, 1992. SLOSH: Sea, lake, and overland surges from 
hurricanes. NOAA Technical Report NWS 48, National Oceanic and Atmospheric Administration, U. S. Department of Commerce, $71 \mathrm{pp}$.

Jones, Stephen C., and David K. Tidwell. 2012. Comprehensive shoreline mapping, Baldwin and Mobile counties, Alabama: Phase III. Open File Report 1204. Geological Survey of Alabama. Tuscaloosa, Ala. 117 pp.

Kelly, William. 28 January 2012. "Import Bahamian sand for beach fills, shore protection board advised." In Palm Beach Daily News.. Palm Beach, Fla.

McKenzie, Natario. 21 October 2016. “No Caribbean disaster insurance for Bahamas.: Tribune 242. www.tribune242.com/news/2016/oct/21/no-caribbean-disaster-insurance-bahamas/

National Oceanic and Atmospheric Administration. 2015. Guidance for considering the use of living shorelines. The National Academies Press. Washington, D.C. 36 pp.

www.habitat.noaa.gov/pdf/noaa_guidance_for_considering_the_use_of_living_shorelines_2015.pdf

Natural Capital Project. March 2016. Natural Capital Project strategic plan, 36 pp. www.naturalcapitalproject.org/wp-content/uploads/2016/03/Strategic-Plan-FINAL-03.14.2016.pdf .

Persad, Joanne. 2016 (draft). Rapid needs assessment for the Commonwealth of The Bahamas. Rep. Caribbean Disaster Emergency Management Agency. N.p.:CDEMA, 2016.

Pierre, Donna. 2016. Rapid needs assessment of Grand Bahama. Rep. Caribbean Disaster Emergency Management Agency. N.p.: CDEMA, 2016.

U.S. National Hurricane Centre. (Year??). "Operational Storm Surge Basis for the Sea, Lake, and Overland Surges from Hurricanes (SLOSH) Model."

Utility Regulation and Competition Authority (URCA). 2016. 2015 annual report and 2016 annual plan. 39 pp.

www.urcabahamas.bs/download/090938200.pdf

Waite, Richard, and Lauretta Burke, Erin Gray, Pieter van Beukering, Luke Brander, Emily McKenzie, Linwood Pendleton, Peter Schuhmann and Emma Tompkins. 2014. Coastal capital: Ecosystem valuation for decision making in the Caribbean. World Resources Institute. Washington, D.C. www.wri.org/publication/coastal-capital-guidebook

Zhang, Junqi and Kumaraswamy, Mohan, M. 2012. 'Public-private-people partnerships (4P) for disaster preparedness, mitigation and post-disaster reconstruction." In Proceedings of the 8th annual conference of the International Institute for Infrastructure, Renewal and Reconstruction (IIIRR), p. 407-416. 

Copyright (c) 2020 United Nations and Inter-American Development Bank. This work is licensed under a Creative Commons IGO 3.0 Attribution-NonCommercial-ShreAlike (CC-IGO 3.0 BY-NC-SA) license (http://creativecommons.org/licenses/by-nc-nd/3.0/igo/legalcode) and may be reproduced with attribution to the IDB and for any non-commercial purpose in its original or in any derivative form, provided that the derivative work is licensed under the same terms as the original. ECLAC and the IDB are not liable for any errors or omissions contained in derivative works and does not guarantee that such derivative works will not infringe the rights of third parties.

Any dispute related to the use of the works of ECLAC and the IDB that cannot be settled amicably shall be submitted to arbitration pursuant to the UNCITRAL rules. The use of IDB's and ECLAC's names for any purpose other than for attribution, and the use of IDB's and ECLAC's logo shall be subject to a separate written license agreement between the IDB and the user and is not authorized as part of this CC-IGO license.

Note that link provided above includes additional terms and conditions of the license.

The opinions expressed in this publication are those of the authors and do not necessarily reflect the views of ECLAC, the Inter-American Development Bank, its Board of Directors, or the countries they represent.

ECLAC Reference Number: LC/TS.2020/32

\section{(c) (1) (3) $\odot$}



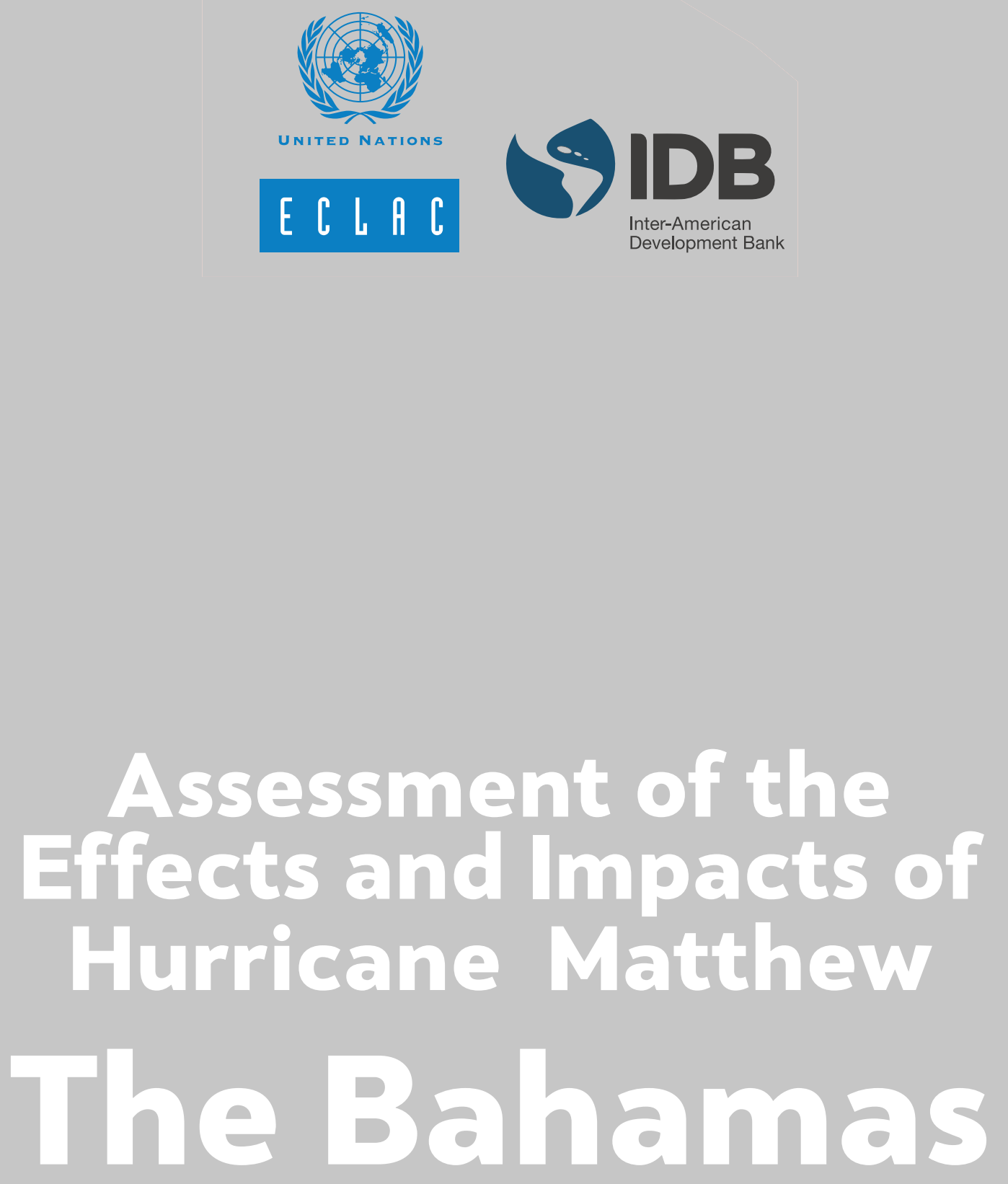